\title{
COMMENTS
}

\section{FINDING A RIGHT IN STATE CONSTITUTIONS \\ FOR COMMUNITY TREATMENT \\ OF THE MENTALLY ILL}

\author{
ANTONY B. KLAPPER $†$ \\ Experience should teach us to be most on our guard to protect liberty \\ when the Government's purposes are beneficent. ${ }^{1}$
}

TABLE OF CONTENTS

INTRODUCTION $\ldots \ldots \ldots \ldots \ldots \ldots \ldots \ldots \ldots \ldots \ldots \ldots \ldots$

I. INSTITUTIONALIZATION AND DEINSTITUTIONALIZATION:

HISTORY AND POLICY . . . . . . . . . . . 748

A. Civil Commitment Procedures . . . . . . . . . . 748

B. Pre-1980s . . . . . . . . . . . . . . . 749

C. 1980 s and $1990 s \ldots \ldots \ldots \ldots \ldots \ldots \ldots$. . . . . . 752

II. Community-Based TREatment AND the Policy

ARgUMENTS FAVORING IT . . . . . . . . . . . . . . 759

A. The Concept of Least Restrictive Alternatives:

Three Progressions . . . . . . . . . . . 759

B. Social Benefits .................. 763

1. Avoiding Unnecessary Civil Commitments ... 763

2. Receiving Effective Liberty-Enhancing

Treatment .............. 766

3. Eliminating the Stigma Through Interaction .. 767

C. Economic Benefits ............... 768

† B.A. 1989, University of Virginia; M.P.A. 1991, Princeton University; J.D. Candidate 1994, University of Pennsylvania. Many thanks go to Professors David Ferleger, Seth Kreimer, and Stephen Morse for reviewing earlier drafts of this Comment, and to Tony Gay, Michael Gilbert, and Valerie Kelly for editing with strict scrutiny the later drafts.

I dedicate this Comment to my father, David, who instilled in me the drive to better myself; to my mother, Carol, who continuously challenges me to reexamine my beliefs; and to my sisters, April and Misty, who have remained my biggest supporters.

${ }^{1}$ Olmstead v. United States, 277 U.S. 438, 479 (1928) (Brandeis, J., dissenting). 
III. SEARCHING FOR A RIGHT TO COMMUNITY-BASED

TREATMENT IN FEDERAL STATUTORY,

CONSTITUTIONAI, AND STATE

STATUTORY REMEDIES . . . . . . . . . . . . 773

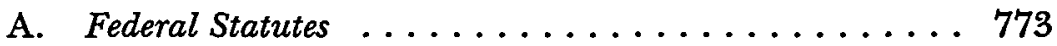

B. Federal Constitution ................. 777

1. The Youngberg Case ... . . . . . . . . 778

2. The Pennhurst II Case . . . . . . . . . . . 780

C. State Statutes . . . . . . . . . . . . . . 781

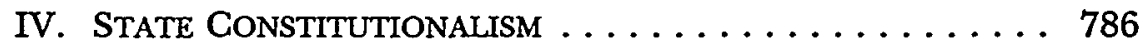

A. History of the Role of State Constitutions . . . . . 787

B. A More Aggressive Jurisprudence . . . . . . . . . . 789

C. Methodologies of State Constitutional Analysis . . . . . 791

D. Tools for Establishing Broader Rights . . . . . . . . 795

V. APPLICATIONS OF THE RIGHT TO COMMUNITY-BASED

TREATMENT in State Constitutions $\ldots \ldots \ldots 796$

A. Substantive Due Process . . . . . . . . . . . 798

1. Reliance on Expansively Interpreted

State Due Process Provisions ........ 801

2. Privacy Provisions in State Constitutions

and the Doctrine of Unconstitutional

Conditions ............. 806

3. Specific Constitutional Provisions

for the Mentally IIl and the

Custody Rationale ............ 814

B. Equal Protection .................. 821

1. Courts Characterizing the Mentally

Ill as a Suspect Class . . . . . . . . 822

2. Courts Liberally Construing

Wealth Classifications . . . . . . . 827

ConClusion . . . . . . . . . . . . . . . 833 


\section{INTRODUCTION}

On January 17, 1993, Christopher Battiste, a homeless man from New York, was arrested for bludgeoning eighty-year-old Doll Mamie Johnson to death in front of her church in the Bronx. Mentally ill for much of his life, Battiste had spent years "drift[ing] in and out of jails, homeless shelters and psychiatric emergency rooms." 2 Less than two months later, Larry Hogue, notorious for his very public and very bizarre behavior on the Upper West Side, was ordered by a state appeals court to be civilly committed ${ }^{3}$ for six months in a psychiatric center in Queens. ${ }^{4}$ At the same time that these events were transpiring in New York, similar stories were being told in cities across the United States. ${ }^{5}$

The frequency of these incidents has helped fuel an ongoing debate between advocates of the mentally ill $^{6}$ and those concerned

${ }^{2}$ Joseph B. Treaster, Behind a Fatal Beating, a Life of Drugs and Rage, N.Y. TMES, Feb. 7, 1993, at A1, 40.

${ }^{3}$ Civil commitment refers to hospitalizing the mentally ill. The terms commitment, hospitalization, and institutionalization will be used interchangeably throughout this Comment.

4 See Joseph P. Fried, Court Orders Confinement of Drug User, N.Y. TIMES, Mar. 2, 1993, at B1. Larry Hogue's odyssey has been a constant source of grist for the press's mill. On August 25, 1993, the New York Times reported that Larry Hogue had been conditionally released the day before from the Queens Psychiatric Center and had gone to live with his son in Bridgeport, Connecticut. See Charisse Jones, Mentally Ill Homeless Man Goes to Bridgeport, N.Y. TMmE, Aug. 25, 1993, at B1, B3. On September 26, 1993, the New York Times once again ran a story on Larry Hogue, reporting that he had been brought back into custody, and raising concerns that the system could not meet his needs. See Robert D. McFadden, Homeless Man of West Side Is Held Again, N.Y. Times, Sept. 26, 1993, at 37, 40.

${ }^{5}$ See Adrianne Carr, The Scary Situation in Our Shelters, WASH. POST, Dec. 13, 1992, at $\mathrm{C} 8$ (noting that a mentally ill homeless person, who had been deemed dangerous by psychiatric professionals, was being tried in the murder of a young woman in Bethesda, Maryland); Malcolm Gladwell, A Brush with Madness: $A$ Tormented Artist Is Free, WASH. POST, May 12, 1993, at B1 (depicting the story of David Moser, who, in a delusional rage, attacked his parents with broken glass in their home in Massachusetts, but was deemed not dangerous enough to be civilly committed); E. Fuller Torrey, The Mental-Health Mess, NAT'L REV., Dec. 28, 1992, at 22, 23 (describing Juan Gonzalez, who killed two people with a sword on New York's Staten Island Ferry; Sylvia Seegrist, who shot ten people in a shopping center near Philadelphia; Laurie Dann, who shot six children in an elementary school in Chicago; Herbert Mullin, who randomly killed thirteen people near San Francisco; and James Bicady, who shot five people in a shopping mall in Atlanta).

"Use of the expression "the mentally ill" is not meant to imply that mental illness defines the individual. While the expression "persons with mental illnesses" is certainly preferable as a descriptive matter, its use has proven to be too cumbersome for purposes of this Comment. 
that America's mental health policies have ignored basic issues of public safety. ${ }^{7}$ The debate was rekindled in the mid- to late-1980s when news reports began chronicling the conditions and actions of the mentally ill homeless. ${ }^{8}$ As the conditions of homelessness have become more visible, Americans have begun to equate homelessness with mental illness and deinstitutionalization ${ }^{9}$ with the homeless mentally ill. ${ }^{10}$ Not surprisingly, the connection between the two has been exaggerated, ${ }^{11}$ and as a result, America's impatience and

${ }^{7}$ Characterized in a less sympathetic light, Washington Post staff writer Malcolm Gladwell notes that " $[\mathrm{t}] \mathrm{his}$ is an area where the paternalism of the medical professions comes into full conflict with the absolutist civil libertarian perspective of the mental health bar." Gladwell, supra note 5, at B9.

${ }^{8}$ See, e.g., Mark A. Davis, Homeless Mentally $I l$ Don't Belong in Institutions, PHILA. INQUIRER, Feb. 11, 1987, at A13 (decrying, as "reactionary," the increased calls for institutionalization of the mentally ill homeless); Jane Gross, A First Look at Homeless Is Raw Sight for Tourists, N.Y. TIMES, Nov. 9, 1987, at B1 (providing vivid details of bloated women with ulcerated legs and of men shouting obscenities); see also Leona L. Bachrach, The Media and Homeless Mentally Ill Persons, 41 Hosp. \& CoMMUNITY PSYCHIATRY 963, 963 (1990) (noting that through the 1980s the media "fail[ed] to draw a clear division between homeless individuals who are mentally ill and those who are not").

${ }^{9}$ Simply stated, deinstitutionalization refers to the removal of patients from hospitals and their placement in alternative care settings within the community. See Ingo Keilitz et al., Least Restrictive Treatment of Involuntary Patients: Translating Concepts into Practice, 29 Sr. LouIS U. L.J. 691, 693, 698 n.30 (1985).

${ }^{10}$ In Boston and New Orleans, for example, public and private agencies knowledgeable about these issues cite "deinstitutionalization" as a primary cause of homelessness among the mentally ill. See Laura D. WAXMan, THE UNITEd STATES CONFERENGE OF MAYORS, MENTALLY ILL AND HOMELESS: A 22-CITY SURVEY 18-19 (1991) [hereinafter MENTALLY ILL AND HOMELESS SURVEY]; see also Lynda Richardson, Business as Usual for Shelter Teams: State's Plans for the Mentally Ill, N.Y. TIMES, Feb. 4, 1993, at B1 (noting how state officials in the aftermath of Doll Mamie Johnson's murder by a homeless mentally ill man took immediate steps to facilitate civil commicment of New York's mentally ill homeless population).

${ }^{11}$ See John Q. LA Fond \& MARY L. DURHAM, BACK TO THE ASYLUM: THE FutURE of MENTAL HEALTh LAW AND POLICY IN THE UNITEd STATES 103 (1992). La Fond and Durham argue that many have exaggerated the proportion of homeless individuals who are mentally ill by putting the figure as high as $90 \%$. "These inaccurate estimates [have] reinforced a natural inclination to assume that a situation so frightening and unfortunate as homelessness must be caused by mental illness rather than by socioeconomic factors .... Id.; $c f$. Jan C. Costello \& James J. Preis, Beyond Least Restrictive Alternative: A Constitutional Right to Treatment for Mentally Disabled Persons in the Community, 20 LOY. L.A. L. REV. 1527, 1532 (1987) (noting that neglect of the homeless population has "reached the public consciousness as a result of publicity surrounding the 'mentally disabled homeless'). A nine-year comparison of the homeless in major American cities has consistently placed the percentage of homeless individuals afflicted with severe mental illness at approximately $30 \%$. See THE UNITED STATES CONFERENCE OF MAYORS, A STATUS REPORT ON HUNGER AND HOMELESSNESS IN AMERICA's CrTIES: 1993 app., tbl. I (1993) (analyzing data from 1985 to 1993 in 26 U.S. cities). 
frustration with its homeless population has served to further alienate an already stigmatized population of mentally ill individuals. ${ }^{12}$

Evidence of this trend can be gleaned from the fact that many states eased their civil commitment criteria; actions which appear to have been motivated by a desire to forcibly remove the homeless masses from city streets. ${ }^{13}$ But by focusing attention on the homeless mentally ill, states have not only ignored the real problems

Echoing La Fond and Durham, Michael Perlin notes that while "conventional wisdom posits that the policy of deinstitutionalization has 'caused" a rise in homelessness, "[t] he blame is misplaced." Michael L. Perlin, Competency, Deinstitutionalization, and Homelessness: A Story of Marginalization, 28 Hous. L. REV. 63, 67 (1991). Perlin lists four factors that have contributed to increased homelessness. First, the baby boom generation has placed increasing demands on housing stock, while the supply has not kept up with the demand. See id. at 74-75. Second, federal funding for subsidized housing, especially for single room occupancy hotels ("SROs"), has decreased dramatically. See id. at 75-77 (noting that federal aid has been reduced by $81 \%$ in the past decade). Third, government aid to the poor has dwindled. See id. at 78-79 (noting that Reagan era purges of the Supplemental Security Income ("SSI") system left 350,000 without benefits). And fourth, unemployment rates have contributed greatly to increased homelessness. See id. at 79.

${ }^{12}$ See MENTALLY ILL AND HOMELESS SURVEY, supra note 10, at 76-78 (depicting increased negativity toward the mentally ill homeless in 17 U.S. cities, including calls in Los Angeles and Louisville to institutionalize these individuals); TASK FORCE ON HOMELESSNESS AND SEVERE MENTAL ILLNESS, OUTCASTS ON MAIN STREET 24 (1992) (noting that "[p]eople with severe mental illnesses have had a long history of being stigmatized-reviled, shunned, shut away, and in previous eras, killed," and that many of the homeless mentally ill today continue to be kept out of certain communities); cf. Steven E. Hyler et al., Homicidal Maniacs and Narcissistic Parasites: Stigmatization of Mentally IIl Persons in the Movies, 42 HOSP. \& COMMUNITY PSYCHIATRY 1044, 1045-46 (1991) (arguing that movie stereotypes that characterize the mentally ill as homicidal maniacs and seductresses tend to stigmatize the mentally ill).

${ }^{13}$ See generally LA FOND \& DURHAM, supra note 11, at ix (noting, in 1992, that there has been a noticeable trend back to the asylum). For a more detailed discussion, see infra notes $52-55$ and accompanying text.

In addition to eased commitment standards, many jurisdictions are "criminalizing the mentally ill." Behind Bars: Criminalizing the Mentally Ill, WASH. POST, Nov. 24, 1992, at E5 (quoting a study conducted by the National Alliance for the Mentally Ill and the Health Research Group of Public Citizen which found that $29 \%$ of the jails nationwide confine seriously mentally ill people who have no criminal charges against them, often because no facilities are available in the community to respond to psychiatric emergencies). According to this study, only five states and the District of Columbia reported that they had no mentally ill people incarcerated without criminal charges. See id. This practice of "mercy bookings" has contributed to the almost 100,000 seriously mentally ill individuals incarcerated. See Torrey, supra note 5, at 23. 
facing the homeless, ${ }^{14}$ but have also managed to diminish or threaten to diminish the rights of the mentally ill. ${ }^{15}$

Many of those concerned with these trends have suggested other avenues for addressing the needs of the mentally ill homeless, avenues that are less restrictive of their rights than civil commitment. ${ }^{16}$ One such approach calls for a restructuring of, and renewed reliance upon, community treatment programs originally intended to help the deinstitutionalized assimilate into the community. ${ }^{17}$ Taking myriad forms, including day- and night-hospital

14 Michael Perlin notes that "[b]y focusing on the mentally ill, [New York City] perpetrates the stereotype that the homeless are insane. ... By categorizing the homeless as insane, no fundamental economic dislocations need to be examined, and society can salve its conscience by attributing the problem to pathology rather than poverty." Perlin, supra note 11, at 112 (quoting Neil McKittnick, The Homeless: Judicial Intervention on Behalf of a Politically Powerless Group, 16 FORDHAM URB. L.J. 389,428 (1988) (alteration in original)).

${ }_{15}$ The number of those committed to institutions is certainly not staggering, and many jurisdictions, in fact, are actually lowering the ranks of their institutionalized. See Celia W. Dugger, A Debate Unstilled, N.Y. TIMES, Jan. 22, 1993, at B2 (noting that Governor Cuomo's new budget proposal will cut the number of patients in mental hospitals from 11,000 to 9700 by 1994). The fact remains, however, that several jurisdictions are easing their commitment criteria or finding alternative methods (such as outpatient treatment) to control the mentally ill. See infra note 58 and accompanying text. Moreover, after each tragic incident is sensationalized in the press, the calls for less liberty and more safety increasingly threaten the liberty interests of the mentally ill. See Carr, supra note 5, at C8 (criticizing the legal system for placing individual rights above personal safety); Dugger, supra, at BI (noting that while the numbers of those institutionalized in the state is decreasing, New York state Mental Health Commissioner, Richard Surles, has been criticizing the city for "failing to act aggressively enough to involuntarily commit mentally ill people who are a danger to themselves or others"); Joseph P. Fried, Court Orders Confinement of Drug User, N.Y. TIMEs, Mar. 2, 1993, at BI (quoting state Attorney General Robert Abrams as saying that the institutionalization of a mentally ill drug abuser will reinforce for "other judges hearing these kinds of cases that they have both the power and responsibility to retain mentally ill and dangerous individuals in the state's psychiatric facilities"); Heather MacDonald, The Tyranny of Freedom, NEwSDAY, Feb. 16, 1993, at 36 (characterizing the current mental health system as "utter madness: a system that disregards the community's right to live free of violence and fear in favor of the 'freedom' of potentially violent psychotics to refuse the therapeutic intervention they so desperately need"); Torrey, supra note 5, at 25 (calling for easier civil commitment criteria); When MICA's Commit Murder, N.Y. TIMES, Jan. 22, 1993, at A24 (editorial page) (arguing that in light of recent violent acts perpetrated by mentally ill chemical abusers ("MICAs"), New York City should step up its efforts to civilly commit those individuals and that emergency room psychiatrists should be held liable for the subsequent behavior of MICAs).

${ }^{16}$ See, e.g., Edmund V. Ludwig, The Mentally Ill Homeless: Evolving Involuntary Commitment Issues, 36 VILL. L. REV. 1085, 1106-09 (1991) (critically analyzing the Joyce Brown case where a New York City homeless woman was removed from the street and sent to Bellevue Hospital and a New York appellate court decision to civilly commit a mentally ill homeless person).

${ }^{17}$ See E. Fuller TORREY, NOWhere to Go: THE Tragic Odyssey OF THE 
care, half-way houses, home-health services, and even employment programs, ${ }^{18}$ community-based mental health services-if properly designed and coordinated with other service delivery systems-are more cost-effective ${ }^{19}$ and less liberty-restricting than hospitalization. If this strategy were adopted, not only would care for the deinstitutionalized improve, but all potentially committable individuals would also benefit from having community treatment settings made available as workable alternatives to hospitalization.

Implicit in the conception of community-based services is the notion that the state should help those in need, but in a manner that is least intrusive of their liberty. Characterized in constitutional terms as the least restrictive alternative doctrine, or the doctrine of

HoMeless MENTALLY ILL 25-29, 110-13 (1988); Dugger, supra note 15, at B2 (noting that "politics has kept the state from shifting enough resources from mental hospitals to services in the communities where mentally ill people now live"); Amy Goldstein, Court Takes over D.C. Mental Services; Judge Gives Reins to Outside Specialist, WASH. POST, May 18, 1993, at A1 (reporting that U.S. District Judge Aubrey Robinson, Jr., appointed a "special" master to accelerate the District of Columbia's efforts at keeping its promise to build a community network of psychiatric services, fully 17 years after a federal appeals court ordered the District of Columbia to comply with its own laws); Sarah Lyall, Pressure Mounts to Keep Psychiatric Centers Open, N.Y. TIMES, March 1, 1993, at B7 ("There's absolutely no question that over the 30-year period of deinstitutionalization, there's been an almost total abdication of the original intent to shift dollars, along with patients, into the community." (quoting Daniel R. Coughlin, Commissioner of Mental Hygiene Services in Broome County, New York)). For a general discussion on one possible way to require states to improve such services, see Jonathan P. Bach, Requiring Due Care in the Process of Patient Deinstitutionalization: Toward a Common Law Approach to Mental Health Care Reform, 98 YALE L.J. $1153,1154-55$ (1989) (arguing that the state retains a duty of care under common law to those whom the state has deinstitutionalized).

${ }^{18}$ See, e.g., CAL. WELF. \& INST. CODE $§ \S 5670.5,5671$ (West Supp. 1993) (stating California's intent to encourage residential treatment programs); HAW. REV. STAT. $\$ 334-3.5$ (Supp. 1992) (establishing a community-based employment program); MISs. CODE ANN. \$41-21-73(4) (1993) (requiring commitment of the mentally ill or retarded to the least restrictive treatment facility); see also David L. Chambers, Alternatives to Civil Commitment of the Mentally Ill: Practical Guides and Constitutional Imperatives, $70 \mathrm{MICH}$. L. REV. 1107, 1118 (1972) (discussing the various forms that community-based treatment programs take); infra notes 85-87 and accompanying text.

${ }^{19}$ See Sam H. Verhovek, Politics Keeps New York State Mental Unit Open, N.Y. TIMES, Oct. 4, 1992, at A1 (noting that because of severe opposition to the closing of several mental hospitals, New York cannot afford the beds needed in community residences, which are "far cheaper and considered by experts to be more humane and more effective in treating most sick people"); Richardson, supra note 10, at B5 (quoting Norman Stiegel, Executive Director of the New York Civil Liberties Union, as blaming the state for "ducking its larger responsibilities to provide more community care"). For a more detailed discussion of how community-based treatment is more effective and cheaper than institutionalization, see infra notes $116-33$ and accompanying text. 
least drastic means, ${ }^{20}$ it has come to be equated with communitybased treatment in the context of mental health law. ${ }^{21}$ From this author's perspective, it would require the state to give thoughtful consideration to the needs of all individuals afflicted with severe or chronic mental illnesses, ${ }^{22}$ whether they are currently institutionalized, deinstitutionalized, or simply at risk of becoming institutionalized for the first time. ${ }^{23}$ Application of the least restrictive means doctrine would not, of course, compromise the effectiveness of treatment. It would not choose less restrictive alternatives that are also less effective. Rather, the doctrine would require state officials to reorder their treatment and funding priorities so that communitybased approaches offer a realistic, as well as preferred, alternative to hospitalization.

Where to find this mandate for community-based services poses yet another problem. Because states have sought to diminish the ranks of their homeless populations by expanding their civil

${ }^{20}$ See Shelton v. Tucker, 364 U.S. 479,488 (1960).

${ }^{21}$ See Keilitz et al., supra note 9, at 693 (arguing that the least restrictive alternatives and deinstitutionalization "have been joined in expression of public policy and legislative intent").

${ }^{22}$ Chronic mental illnesses, also characterized as serious mental illnesses, have yet to be consistently defined. See Leona L. Bachrach, Defining Chronic Mental Illness: A Concept Paper, 39 HOSP. \& COMMUNITY PSYCHIATRY 383, 384-86 (1988). Most statutory definitions include diagnosis, duration, and disability criteria. For example, Arizona defines the "seriously mentally ill" as individuals with a schizophrenic, major affective, or paranoid disorder (diagnosis), who have had persistent psychotic symptoms (duration), and as a result, are dysfunctional emotionally and behaviorally in such areas as work, social relations, and self care (disability). See ARIz. REv. STAT. ANN. § 36-550(4) (Supp. 1993). Questions remain, however, particularly regarding the durational element. See WIS. STAT. ANN. \$ 51.01(3g) (West 1987).

According to the American Psychiatric Association, an individual is afflicted with a severe mental illness when "[s] everal symptoms [are] in excess of those required to make the diagnosis and [the] symptoms markedly interfere with occupational functioning or with usual social activities or relationships with others." AMERICAN Psychiatric Assoc., Diagnostic and Statistical Manual of MeNTal Disorders (DSM-III-R) 24 (1987). As a general matter, however, the "severity" of mental illness differs with respect to the various mental disorders. Schizophrenia, for example, which at some point always involves "delusions, hallucinations, or [other] ... disturbances," see id. at 187, becomes "chronic" when the symptoms of schizophrenia last for more than two years. See id. at 195. The definition of schizophrenia, itself, incorporates a time dimension, requiring the continuous signs of the illness for at least six months. See id. at 190. Despite the APA's best efforts, however, most states use prior hospitalization as the primary indicator of chronicity. See Bachrach, supra, at 385 .

${ }^{23}$ As this Comment defines them, those "at risk" of being civilly committed are those who have been brought into the civil commitment process either voluntarily or involuntarily and whose placement fate awaits. 
commitment criteria, state statutes are not likely to be a source of great protection. Although most state statutes require or allow the consideration of less restrictive alternatives in their civil commitment proceedings, ${ }^{24}$ few actually follow the mandates and even fewer are likely to in the future. ${ }^{25}$ Federal statutes are not likely to be of much help either. Most federal statutory provisions are directed towards the mentally retarded, not the mentally ill. ${ }^{26}$ Moreover, as interpreted by the courts, no federal statute has been found to require states to consider less restrictive alternatives to civil commitment. ${ }^{27}$

As for a constitutional mandate supporting the right to community-based services, cases decided by the U.S. Supreme Court over twenty years ago may have held the key. But within the past twenty years, the Supreme Court has undergone a retrenchment of its own, rendering it an unlikely source of protection for the mentally ill. ${ }^{28}$ As the Supreme Court has retreated, however, state courts have tended to fill the void. The re-emergence of state courts and state constitutions as sources of aggressive rights protection bodes well for the establishment, in a new context, of a right to treatment in the least restrictive environment. ${ }^{29}$ Although the scope of state court decisions that rest on state constitutional provisions is limited, enough of a foundation has been laid upon which additional rights for the mentally ill may be built.

Part I of the Comment will trace the history of civil commitment in the United States, detailing the factors leading up to deinstitutionalization, the failures of deinstitutionalization, and the retrenchment of rights in the $1980 \mathrm{~s}$ and 1990s. Part II will begin by exploring the concept of least restrictive alternatives and its connection with the doctrine of community-based alternatives. Once theoretically established, the doctrine of community-based treatment will be analyzed through political lenses, as the Comment explores the economic and social benefits associated with community-based approaches to mental health. Part III will detail why resort to federal statutory and constitutional, as well as state statutory remedies is not likely to be an effective strategy, as they have

\footnotetext{
${ }^{24}$ See infra text accompanying note 186.

${ }^{25}$ See infra notes 187-92 and accompanying text.

${ }^{26}$ See infra text accompanying notes $146-51$.

${ }^{27}$ See infra text accompanying notes 146-56.

${ }^{28}$ See infra text accompanying notes $160-79$.

${ }^{29}$ See infra text accompanying notes 205-06.
} 
increasingly tended to favor the concerns of the majority over the rights of the minority. Part IV urges advocates for the mentally ill to resort to state constitutionalism in order to preserve the liberty interests of their clients. Part $\mathrm{V}$ proposes several ways in which the due process and equal protection provisions of state constitutions can serve this end.

\section{INSTITUTIONAIIZATION AND DEINSTITUTIONALIZATION: HISTORY AND POLICY}

\section{A. Civil Commitment Procedures}

The state's power to commit a mentally ill individual must rest on one of two grounds. Either the commitment is justified by the state's police power or its parens patriae power. ${ }^{30}$ Under the police power rationale, commitment is necessary to protect the public from individuals the state considers to be potentially dangerous. ${ }^{31}$ Under the parens patriae power, the state assumes the obligation to protect those who cannot protect themselves. ${ }^{32}$

${ }^{30}$ See Samuel J. BRakel et al., The Mentally Disabled and the Law 24 (1985). Brakel's work is one of the most comprehensive, as well as one of the most often cited, works on the mentally ill.

${ }^{31}$ Before committing the noncriminal mentally ill, the state, in most jurisdictions, is required to show with clear and convincing proof, that (1) the individual is unable to conform his or her conduct to the requirements of the law or to the limits of social tolerance; (2) the individual is unable to appreciate the deterrent force of the law; and (3) the individual is therefore potentially dangerous as measured by both magnitude and probability of harm. See id. at 24-25. For all three criteria, the individual's deficiencies must stem from his or her mental illness. See id.

${ }^{32}$ To satisfy the requirements justifying parens patriae commitment, the state must show, with clear and convincing proof, that (1) the individual lacks the competence, because of his or her severe mental illness, to make decisions affecting her condition and thus is unable to seek appropriate treatment on her own; and (2) the potential of harm to the patient is so great that a deprivation of liberty for the patient's own good is warranted. See id. at 24. States have increasingly allowed the commitment of "gravely disabled" individuals, independent of a finding of decisional incompetence. See id. at 24 n.28; Fay A. Freedman, The Psychiatrist's Dilemma: Protect the Public or Safeguard Individual Liberty?, 11 U. PUGET SOUND L. REv. 255, 264 n.58 (1989) (discussing how today the doctrine of parens patriae "authorizes involuntary commitment of mentally ill persons who cannot care for themselves, are unable to seek appropriate treatment or are gravely disabled"); see also infra text accompanying notes 181-83. Other states have followed the American Psychiatric Association's Model Law provision for commitment of those "likely to suffer substantial mental or physical deterioration." Clifford D. Stromberg \& Alan A. Stone, Statute: A Model State Law on Civil Commitment of the Mentally Ill, 20 HARV. J. ON LEGIS. 275, 280 (1983). For a more extensive discussion of the implications of these more lenient standards, see infra discussion accompanying notes 55-65. 
Although the procedures for civil commitment vary, typical state proceedings are either initiated through third party petitions to the state courts or through emergency detentions made by police officers. Commitment proceedings that follow judicial channels are typically initiated by family members or other individuals who can personally attest to the actions of the proposed patient. The petitions must allege that the proposed patient is mentally ill and that the state's criteria for commitment are satisfied. Moreover, in most jurisdictions, a medical certificate supporting the petitioner's clinical claims is required. If, based on this information, the reviewing judge has probable cause to believe that the state's commitment criteria are satisfied, the proposed patient will be subjected to a brief observational stay in a psychiatric ward so that an independent examination can be conducted. If the commitment process is initiated on an emergency basis, these preliminary steps are usually bypassed, and the proposed patient is immediately detained for purposes of examination.

In either case, a commitment hearing takes place after the examination is complete. In most states the hearing is automatic, but some states only grant review hearings upon request. At the hearing, the proposed patient enjoys a panoply of due process protections, including the right to legal counsel, a limited right to confront adverse witnesses, and in some states, the right to a jury trial. At the close of the hearing the court determines whether by clear and convincing evidence the proposed patient is mentally ill and satisfies the state's commitment criteria. If the appropriate criteria are, in fact, met, the court then considers where best to treat the patient. ${ }^{33}$

Although these formalistic procedures have remained relatively constant over time, the actual implementation of civil commitment laws has changed radically over the years.

\section{B. Pre-1980s}

Guided by a combination of goodwill, self-interest, and scientific bravado, progressive reformers in the early twentieth century sought not only to care for, but also to remove, the mentally ill from crowded city tenements. Between 1900 and 1940 they

${ }^{33}$ For a good, though somewhat dated, description of the civil commitment process, see BRAKEL ET AL., supra note 30 , at 56-73. Alternatively, one could simply browse through the civil commitment provisions of the fifty states. See infra note 337 . 
succeeded in increasing the number of institutionalized mentally ill from 150,000 to approximately $445,0000^{34}$ By 1955 , inpatient episodes $^{35}$ totalled 819,000 in state and county mental hospitals. ${ }^{36}$

By the 1960s, however, concerns for the civil rights of patients, ${ }^{37}$ among other things, ${ }^{38}$ inspired a trend towards deinstitu-

34 See LA FOND \& DURHAM, supra note 11, at 83. Edward Purcell describes this era as one highlighted by an emergent faith in the good uses of science that over time lost its teleological zeal and lapsed into mere instrumentalism. Science was no longer good or bad; it was just science:

Rapid technological advance[s] contributed further to the general faith in science and confirmed it as the most reliable method of attaining useful knowledge.... [and as] the perfect instrument to bring about the continuous improvement of society.

....

By the second decade of the twentieth century the ideal of a science of society was firmly entrenched in American thought.

....

Gradually methodology replaced moralism in the minds of many younger reformers and social scientists, and the instrument of social research came to overwhelm the goal of social reform.

Edward A. Purcell, JR., The Crisis of Democratic Theory: ScIentific NAturalism AND THE Problem of Value 6, 15, 25 (1973). Purcell provides a wonderful guide to the changing themes of American cultural and intellectual thought from 1870 to 1960 .

Characterized as the "medical model" years, civil commitments during this period worked on the assumption that the mentally ill needed someone else to provide decision-making authority. Not only were doctors given broad authority to involuntarily hospitalize citizens, but the superintendents and staff who ran these institutions were given almost complete discretion about decisions affecting the patient. See LA FOND \& DURHAM, supra note 11, at 83-84. La Fond and Durham note that "[s]uperintendents were under no legal obligation to review cases for discharge or to justify a decision to retain a patient." Id. Moreover, there often were no maximum limits on how long a patient could remain committed; most patients simply died while in institutions. See BRAKEL ET AL., supra note 30, at 203. In fact, when patients walked through the hospital doors, they lost not only their freedom, but also other rights not directly associated with the commitment, such as voting and property rights. See LA FOND \& DURHAM, supra note 11, at 84.

These practices were justified on several grounds. First, "[m]ost mentally disabled people were assumed to be incapable of comprehending or exercising their rights. In addition, severely limiting many personal rights was believed necessary for effective treatment. Finally, orderly hospital administration required the restriction of many patient privileges." Id.

${ }^{35}$ Inpatient episodes are the number of patients in residence at the beginning of a 12-month reporting period, plus those admitted during that period. During deinstitutionalization, the number of inpatient episodes was cut in half. See Costello \& Preis, supra note 11 , at 1531-32 n.20 (noting that the population in state mental hospitals declined from 560,000 in 1950 to less than 140,000 in 1980).

${ }^{36}$ See LA FOND \& DURHAM, supra note 11, at 83.

${ }^{37}$ Exposés on the sordid conditions within mental institutions, such as Albert Deutsch's book, The Mentally IIl in America, contributed mightily to the vigilant 
tionalization, a movement marked both by reduced levels of commitment and increased due process protections for those still committed. $^{39}$ This concern with civil rights was reflected best by the willingness of courts both to tighten the criteria for identifying committable individuals and to create procedural and substantive safeguards, including the right to treatment in the least restrictive environment. ${ }^{40}$ Spurred on by these judicial mandates, state

concerns of civil rights activists. See LA FOND \& DURHAM, supra note 11 , at 85 . One particularly poignant passage in Deutsch's book recalls: "In some of the wards there were scenes that rivaled the horrors of the Nazi concentration camps-hundreds of naked mental patients herded into huge, barnlike, filth-infested wards, in all degrees of deterioration, untended and untreated, stripped of every vestige of human decency, many in stages of semi-starvation." ALBERT DEUTSCH, THE MENTALLY ILI IN AMERICA: A History OF THEIR CARE AND TREATMENT FROM COLONIAI TIMES 449 (2d ed. 1949). See generally ERVING GOFFMAN, AsYLUMS (1961) (analyzing the social conditions of patients in state mental hospitals).

${ }^{38}$ Psychotropic drugs, a group of chemical agents that have an effect on the mind, were introduced to treat mental illness. See Costello \& Preis, supra note 11, at 153132 n.20. These drugs served to inhibit the more serious manifestations of mental illness, thus the need for institutionalization was reduced. See id.; see also BRAKEL ET AL., supra note 30, at 47-48, 328-29 (discussing four categories of psychotropic drugsantipsychotic, antidepressant, lithium, and anti-anxiety drugs-and the side effects associated with each); Ludwig, supra, note 16, at 1088 (discussing clozapine, a new drug that some think may facilitate the release of as many as $30 \%$ of the long-term patients still in mental hospitals).

Also of importance was the fiscal health of states during the 1960s. See BRAKEL ET AL., supra note 30, at 203 n.3. In addition to the overcrowded conditions of mental facilities in the 1960 s, see id. at 203 , presumably requiring ever greater public expenditures for upkeep and manpower, federal law, which favored community-based treatment, had created economic incentives for states to discharge institutional residents. See LA FOND \& DURHAM, supra note 11, at 89 (noting that federal law prevented patients at state institutions and mental hospitals from receiving benefits during inpatient treatment, but did reimburse some nursing homes and other health care providers). "The 1966 amendments to the Comprehensive Health Planning and Public Health Services Act mandated that 15 percent of state grant allotments for public health services be directed toward community-based mental health services. By 1967, this proportion was increased to 70 percent." Id. Not surprisingly, states took advantage of this federal largess. See id. at 90.

${ }^{39}$ See Stephen J. Morse, A Preference for Liberty: The Case Against Involuntary Commitment of the Mentally Disabled, 70 CAL. L. REv. 54, 55 (1982). As social reformers, psychiatrists, lawyers, and political leaders became more aware of the decrepit and horribly dehumanizing conditions of mental institutions, states began to reform their commitment laws and courts began to apply "stringent substantive and procedural due process protections to the involuntary commitment process." Id.; see also Perlin, supra note 11, at 83 (noting that social reformers, psychiatrists, lawyers, and political leaders were each responsible in part for creating alternatives to institutions).

${ }^{40}$ See BRAREL ET AL., supra note 30, at 26; LA FOND \& DURHAM, supra note 11, at 95-97. In a decision reflecting the liberal spirit of the times, the District of Columbia Circuit Court of Appeals held that district courts should bear the burden of inquiring 
legislatures also began to reform the civil commitment process and to enact new laws to protect the liberty interests of the mentally ill. . $^{41}$

\section{1980 s and 1990s}

By the 1980s, it became clear that the progressive roots planted during the previous generation had not fully taken hold. As one commentator notes:

[D]einstitutionalization ... has not lived up to its promises and ... the ideal of community treatment has resulted in the abandonment of many mentally disabled persons to virtually unsupervised, unprotected lives in flophouses located in dangerous or delapidated [sic] areas or even in "psychiatric ghettoes" that have sprung up in some of our larger cities. . . The irony of the original least restrictive alternative case, Lake $v$. Cameron, was that there turned out to be no alternative, and the patient, having been accorded an empty right, remained hospitalized for the remaining five years of her life. ${ }^{42}$

into "other alternative courses of treatment," more suitable to the appellant's needs than civil commitment. Lake v. Cameron, 364 F.2d 657, 661 (D.C. Cir. 1966) (reading this requirement into the District of Columbia Code, but not finding a constitutional right to less restrictive treatment alternatives).

${ }^{41}$ See LA FOND \& DURHAM, supra note 11, at 90-92 (noting that the courts compelled state legislatures and agencies into action by holding several state commitment statutes unconstitutional, thereby forcing legislatures to address the courts' concerns). For example, many states not only limited commitment to those individuals who were dangerous either to themselves or to others, but also defined dangerousness by whether the danger was "imminent" and "substantial," intending that only the most pressing public concerns would warrant civil commitment. See id. at $92-93$.

12 BRAKEL ET AL., supra note 30, at 31 . In the 1960 s, states often released patients who should not have been released, simply to capitalize on the availability of federal funds for community mental health centers ("CMHCs"). See Torrey, supra note 5, at 23. Once patients were released, community facilities did not have the resources to keep track of everyone who depended on their services. The disappearance of single room occupancy hotels, due to the increasing gentrification of the inner cities, also dealt a particularly heavy blow to the mentally ill who not only needed a bed, but also an address where benefit checks could be received. See LA FOND \& DURHAM, supra note 11, at 104; TORREY, supra note 17, at 141-42.

Today, states continue to "dump" their patients. See William Claiborne, 'Quaint' Maine Battles Urban Problem as Facilities Release Mentally Ill Patients, WASH. POST, Mar. 9, 1993, at A9 (noting that "financially strapped state mental hospitals throughout Maine are increasingly 'dumping' severely disturbed patients into the streets to cut $\left.\operatorname{costs}^{n}\right)$. The willingness of states to release as many patients as possible, and the resulting housing shortage has combined to increase the homeless population. See LA FOND \& DURHAM, supra note 10, at 103, 105; see also Dugger, supra note 15, at B2 (noting that the "stock of single room occupancy hotels that traditionally provided the 
Part of the problem was transforming community mental health centers from merely helping the "worried well" to assisting the chronically mentally ill. ${ }^{43}$ As one commentator noted with a tinge of irony, " $[t]$ here appears to be virtually no relationship between community mental health centers and community services for the mentally ill. ${ }^{n 4}$ For the deinstitutionalized who needed continuing psychiatric aftercare services, the hope that community mental health centers would provide those services was a false one. ${ }^{45}$

The result has been a constant flow of mentally ill individuals out of state mental institutions, into the community, and then back into the institutions. The chronically mentally ill:

deteriorate in the community to the point where they are admitted in acute crisis to a hospital, oftentimes via the local jail. They are then stabilized on medication in the hospital and released with no discharge planning or aftercare services. Without treatment or community support services, they again decompensate to the point of requiring hospitalization, revolving continuously back and forth between hospitals and the streets. ${ }^{46}$

mentally ill with a cheap place to stay disappeared as developers upgraded the properties); Sarah Lyall, Red Tape Thwarts Efforts to House Mentally Ill, N.Y. TIMES, Mar. 8, 1993, at B1 (noting that community opposition to the construction of homes for the mentally ill and tensions between city and state governments have slowed down efforts to build these units).

13 See LA FOND \& DURHAM, supra note 11, at 109 (describing the "worried well" as those wanting brief, intermittent therapy, such as marriage counseling or stress management). The "worried well" benefitted, but the "programs did not prove successful with chronic patients whose disabilities require[d] management over an entire lifetime." Id. Without greater federal assistance or state support, these community organizations could not expand their services to meet the needs of the chronically mentally ill. See id. at 110-11.

In fact, many community mental health networks were not only ill-equipped to handle the mentally ill, but in the case of the homeless mentally ill, many of these organizations were also simply unwilling to get involved. See Carr, supra note 5, at C8. But see Shelley Brook et al., Training Volunteers to Work with the Chronic Mentally Ill in the Community, 40 HOSP. \& COMMUNITY PSYCHIATRY 853, 853-54 (1989) (arguing that careful training of volunteers can improve the patients' treatment needs, as well as the volunteers' experience); see also Stacy E. Seicshnaydre, Note, Community Mental Health Treatment for the Mentally Ill-When Does Less Restrictive Treatment Become a Right? 66 TUL. L. REV. 1971, 1973 n.8 (1992) (noting that many of the homeless mentally ill would refuse treatment even when it was available).

4 TORREY, supra note 17, at 26; Bob Herbert, Mental Health Failures, N.Y. TIMES, Sept. $5,1993, \S 4$, at 11 (noting that although one billion dollars is spent each year on community mental health services in New York state, the chronically mentally ill are not benefitted).

${ }^{45}$ See TORREY, supra note 17 , at $142-50$.

${ }^{46}$ Costello \& Preis, supra note 11, at 1532. While the number of patients in public mental institutions at any one time has fallen precipitously, the number of those 
Today, deinstitutionalization has become associated with crime, ${ }^{47}$ homelessness, ${ }^{48}$ and public anxiety. ${ }^{49}$ Of course, many of the civil rights advances for the mentally ill remain intact. ${ }^{50}$ Constitutional and statutory protections have not been totally abandoned. Nonetheless, majoritarian values and a "law and order" mentality have begun to threaten the civil libertarian advances that favored the mentally ill. ${ }^{51}$

One force behind this trend has been the American Psychiatric Association (APA). ${ }^{52}$ In its Model Law for Civil Commitment, promulgated in 1983, the APA suggested expanding involuntary commitment to persons "likely to cause harm to [themselves] or to suffer substantial mental or physical deterioration, or . . . likely to cause harm to others. ${ }^{n 3}$ Under the traditional understanding of parens patriae and police power justifications for civil commitment, the variable "harm" had always been a necessary criterion for civil commitment. ${ }^{54}$ Under the suggested model law, however, the APA, "[s]ignificantly ... expand[ed] current parens patriae

admitted to institutions has actually increased. See BRAKEL ET AL., supra note 30, at 47; see also Costello \& Preis, supra note 11, at 1554-55 n.124 (noting that in one California hospital, the rehospitalization rate has topped 50\%); Charles A. Kiesler, Mental Hospitals and Alternative Care: Noninstitutionalization as Potential Public Policy for Mental Patients, 37 AM. PsYcHOL. 349, 349-50 (1982) (noting that the number of inpatient episodes increased between 1955 and 1975 from 477,000 to 1.2 million).

${ }^{47}$ Many of the mentally ill who remained in communities without adequate support structures got into trouble with the law. Once in jail, both the social and clinical condition of these individuals worsened. See LA FOND \& DURHAM, supra note 11, at 101-02; see also TORREY, supra note 17, at 13 (noting that many of the mentally ill were charged with petty crimes simply to get them off the streets); supra note 13 .

${ }^{18}$ See LA FOND \& DURHAM, supra note 11 , at 100 . Soon scholars were pointing fingers at deinstitutionalization for the growth of the homeless population, reinforcing public perceptions and stereotypes. See, e.g., TORREY, supra note 17, at $141-42$ (1988); $c f$. H. Richard Lamb, Deinstitutionalization and the Homeless Mentally Ill, in THE HOMELESS MENTALIY ILL 55, 55 (H. Richard Lamb ed., 1984) (noting that the poor implementation of deinstitutionalization has contributed to the homelessness problem); see also supra note 10.

${ }^{49}$ Deinstitutionalization as a concept is problematic because it has a "pejorative connotation, evoking images of the discharge of a great number of patients into communities that lack adequate planning or funding for community care." Keilitz et al., supra note 9, at 699; see also supra note 12 .

${ }_{50}$ See infra text accompanying notes $185-86$.

${ }^{51}$ See LA FOND \& DURHAM, supra note 11, at 15.

${ }^{52}$ See Stromberg \& Stone, supra note 32, at 275 (presenting and commenting on the model APA statute on civil commitment).

${ }^{33} \mathrm{Id}$. at 330 (emphasis added).

34 See supra notes 30-32. "These 'need for treatment' provisions represented a clear departure from the narrow commitment criteria of the 1960 s, which required dangerousness to self or others." LA FOND \& DURHAM, supra note 11, at 118. 
commitment" authority to reach "many of those severely mentally ill people who ... roam the streets aimlessly and without hope," regardless of the danger they pose to themselves or to others. ${ }^{55}$ As a practical matter, therefore, the APA proposal called for the commitment of those who had been deinstitutionalized, but, because of inadequate aftercare services, were at risk of being recommitted. These individuals were deemed a "danger" to themselves not because of what they would actually do to themselves, but because of what they would, in fact, not do for themselves.

Several states have incorporated this "passive harm" (deterioration) standard into their commitment statutes. ${ }^{56}$ Several other states have simply interpreted their civil commitment laws broadly and construed the "harm" requirement expansively in order to reach the homeless. ${ }^{57}$ And for those states reluctant to alter the

${ }^{35}$ Stromberg \& Stone, supra note 32 , at $280-81$.

${ }^{36}$ See ALA. CODE § 22-52-10.2 (Supp. 1993) (noting that one "may be committed to outpatient treatment if . . . as a result of the mental illness the respondent ... will continue to experience deterioration of the ability to function independently"); ALASKA STAT. \$ 47.30.915(7)(B) (1990 \& Supp. 1992) (describing a civilly committable individual as one who "will, if not treated, suffer or continue to suffer ... and this distress is associated with significant impairment of judgment, reason, or behavior causing a substantial deterioration of the person's previous ability to function independently"); KAN. STAT. ANN. § 59-2902(g)(2) (Supp. 1992) (defining "[1]ikely to cause harm to self or others' [as a person who] . . . is unable ... to provide for ... basic needs . . causing a substantial deterioration of the person's ability to function on the person's own"); MONT. CODE ANN. \$ 53-21-102(8)(e) (1991) (defining the "'[m]entally ill' [as those] suffering from a mental disorder which ... will, if untreated, predictably result in further serious deterioration in the mental condition of the person"); N.C. GEN. STAT. \$ 122C-261(a) (1989 \& Supp. 1992) (characterizing as civilly committable an individual "in need of treatment in order to prevent further disability or deterioration that would predictably result in dangerousness"); N.D. CENT. CODE \& 25-03.1-02(11)(c) (Supp. 1993) (defining a "'[p]erson requiring treatment' [as one] who ... if ... not treated[,] there exists a serious risk of harm [which means] a substantial likelihood of ... [s] ubstantial deterioration in physical health ..., based upon recent poor . . . judgment in providing one's shelter, nutrition or personal care"); OR. REV. STAT. $\$ 426.005$ (2)(c)(C), (D) (Supp. 1992) (defining a "'[m]entally ill person' [as one] who ... [i]]s exhibiting symptoms or behavior substantially similar to those that preceded and led to [prior] hospitalization. ..., and [u]nless treated, will continue ... to physically or mentally deteriorate"); TEX. HEALTH \& SAFETY CODE ANN. § 574.034(a)(2)(C) (West 1992) (characterizing as civilly committable one who "will, if not treated, ... continue to experience deterioration of his ability to function independently"); WASH. REV. CODE ANN. § 71.05.020(1)(b) (West 1992) (characterizing as civilly committable one who "manifests severe deterioration in routine functioning").

Note further that most states have also adopted a "gravely disabled" or "unable to provide for basic needs" standard, which similarly extends the parens patriae authority to "passive" harms. See infra note 183.

${ }^{57}$ For example, in the early 1980 s, New York social workers were authorized to 
terms or interpretation of their inpatient commitment provisions, the growing national trend has been towards outpatient $t^{58}$ and

detain and seek commitment of those who refused shelter during the brutal winter months. The underlying assumptions for these commitments were that one had to be insane to brave sub-freezing temperatures, and that this behavior placed homeless individuals in "grave danger" of harming themselves. Although New York commitment statutes would only allow civil commitment of those proven to be mentally ill and imminently dangerous to themselves or to others, Mayor Edward Koch broadly interpreted the state's commitment statutes to involuntarily detain the homeless who chose to brave the elements. See Mark S. Kaufman, "Crazy" Until Proven Innocent? Civil Commitment of the Mentally Ill Homeless, 19 Colum. Hum. RTS. L. REv. 333, 339-40 (1988); see also Boggs v. New York City Health \& Hosps. Corp., 523 N.Y.S.2d 71, 86 (App. Div. 1987) (rejecting arguments that the problems of Joyce Brown, a homeless person, resulted from a lack of adequate housing for the poor, and not mental illness), appeal dismissed, 525 N.Y.S.2d 796 (1988); Ludwig, supra note 16 , at 1104-11 (detailing this much publicized case).

Other states have upheld these expanded commitment criteria despite constitutional challenges based on claims of overbreadth and vagueness. See, e.g., In re LaBelle, 728 P.2d 138, 144-45 (Wash. 1986) (upholding Washington's "gravely disabled" standard, while acknowledging that inquiries under this standard may involve "imposing majoritarian values on a person's chosen lifestyle"). But see In re Long, 606 N.E.2d 1259, 1263-64 (Ill. App. Ct. 1992) (noting that " [c]ontrary to the State's assertion, a person is free to live on the street, if the person chooses to do so"); In re J.A.D., 492 N.W.2d 82, 85 (N.D. 1992) (noting that "[n]ot all homeless people are mentally ill and in need of treatment. . . [The problems of homelessness] may also be the result of economic hardship or simply lifestyle choice").

${ }_{58}$ Envisioned as a compromise between community treatment proponents and civil commitment proponents, involuntary outpatient commitments generally refer to the coerced community placement of nondangerous individuals either initially or after release from a state mental hospital. See Steven J. Schwartz \& Cathy E. Costanzo, Compelling Treatment in the Community: Distorted Doctrines and Violated Values, 20 LOY. L.A. L. REV. 1329, 1346-47 (1987).

Several commentators believe that outpatient commitments lead to unnecessary restraints on patients who do not meet the conventional criteria for involuntary treatment. Schwartz and Costanzo, for example, argue that outpatient commitments extend involuntary treatment to those who fit the APA's "deterioration" standard, as well as to those not quite as bad off. See id. at 1361, 1367 (noting North Carolina and Georgia as examples and citing their statutes, N.C. GEN. STAT. $\S \$ 122 \mathrm{C}-263(d)(1)(2)$ (1992) and GA. CODE ANN. § 37-3-1(12.1)(A) (Supp. 1993), which provide outpatient commitment based on a "deterioration" standard); see also Robert D. Miller \& Paul B. Fiddleman, Outpatient Commitment: Treatment in the Least Restrictive Environment?, 35 HOSP. \& COMMUNITY PSYCHIATRY 147, $149-50$ (1984) (describing outpatient commitments as less restrictive, but acknowledging that oftentimes outpatients occur because judges cannot legally justify inpatient treatment, but feel treatment is advisable, and because mental health professionals are often pressured to get unpleasant people off the street).

As of 1987, 31 states and the District of Columbia either allowed or mandated outpatient judicial commitments. See Schwartz \& Costanzo, supra, at 1363-64 \& nn.144-47. Schwartz and Costanzo further noted that "the only jurisdictions which have substantially amended their commitment laws," are the ones that have passed comprehensive provisions for outpatient commitment, "lending substantial support to the claim that comprehensive schemes for involuntary community treatment are 
conditional commitments, ${ }^{59}$ extending the state's parens patriae powers well beyond their traditional limits. The increased use of outpatient and conditional commitments and "deterioration" provisions has not only enabled states to maintain control over the mentally ill, but has also enabled states to avoid many of the due process requirements constitutionally and statutorily associated with inpatient commitments. ${ }^{60}$ Not immune to this retrenchment of rights, many courts, including the U.S. Supreme Court, have narrowed the range of protections available to the mentally ill. ${ }^{61}$ Many other courts have simply adopted a posture of judicial restraint, not only refusing to second-guess statutory trends towards eased civil commitment criteria, but also the psychiatric professionals' determinations of who requires civil commitment. ${ }^{62}$ Some courts have simply ignored statutory provisions requiring that the least restrictive alternatives be considered before one is civilly committed. ${ }^{63}$

a national trend." Id. at 1366.

${ }^{59}$ Conditional releases generally involve allowing the patient to be deinstitutionalized as long as certain requirements are met. For example, a release order may stipulate that the individual periodically return to the institution for follow-up care or seek treatment in an outpatient facility. Failure to adjust to the outside world or to properly comply with these "conditions" may result in the individual being returned to the asylum. See, e.g., IDAHO CODE $\$ \S 66-338,-339$ (1989); N.C. GEN. STAT. § 122C-277(a) (1989 \& Supp. 1992); see also BRAKEL ET AL., supra note 30, at 205. As Brakel notes, conditional release provisions "are of little practical value unless there are adequate outpatient facilities in each jurisdiction that work in close cooperation with the mental institutions." Id. at 207.

${ }^{60}$ See BRAKEL ET AL., supra note 30, at 120-21 (listing several state due process statutory provisions for inpatient commitments).

${ }^{61}$ See infra text accompanying notes $164-79$.

${ }^{62}$ See LA FOND \& DURHAM, supra note 11, at 117-19; see also Youngberg v. Romeo, 457 U.S. 307, 322 (1982) (establishing the deferential standard); Kaufman, supra note 57 , at 362 (noting that "[j]udges have routinely deferred to the psychiatrist's expert testimony, abdicating their decisional role to the medical professional, even when their intuitions tell them that the professional's testimony is highly inaccurate").

When courts do second-guess the mental health professionals, it oftentimes results in a decision to commit. See, e.g., State v. Johnson, 843 P.2d 985, 986 (Or. Ct. App. 1992) (holding that homeless person was unable to meet her basic personal needs for food and shelter due to a mental disorder, despite examiners' having determined that there was no disorder); State v. Evjen, 826 P.2d 92, 92-93 (Or. Ct. App. 1992) (basing decision to commit on history of appellant's inability to take medication, despite examiner's findings to the contrary).

${ }^{63}$ See, e.g., In re Robinson, 601 N.E.2d 712, 717 (IIl. 1992) (holding as "harmless error" the state's failure to present a predispositive report as to what less restrictive alternatives exist in the community). See generally BRAKEL ET AL., supra note 30, at 28 (noting that courts ignore statutory provisions largely because they are "overly complicated" and mostly "unnecessary"); Stromberg \& Stone, supra note 32, at 332-33 (noting that while 35 states require that least restrictive alternatives be considered before institutionalizing someone, "this requirement is more aspirational than real"). 
The result of these statutory and judicial trends has not simply been a retrenchment in the niceties of due process. Instead, at least in some of the states that have expanded their civil commitment criteria, the result has been significant increases in the number of those civilly committed. ${ }^{64}$ In Washington state, for instance, La Fond and Durham point to some startling and depressing developments:

When Washington State ... changed its law in 1979 to permit commitment of mentally ill individuals in need of treatment as well as those who were dangerous, there was a 180 percent increase in total admissions to the largest state mental hospital over the two years following the legal change. Involuntary admissions increased by 91 percent in the first year after the legal change. Involuntary admissions actually began to rise nine months before the effective date of the revised statute, the result of an anticipation effect in which mental health professionals and judges simply operated as though the new statute was actually in effect. ${ }^{65}$

With the threat of expanded institutionalization on the horizon, and the continued neglect of the deinstitutionalized, we need a very powerful arsenal of policy and legal arguments to combat this increasing retrenchment of the rights of the mentally ill. Part II sets the stage by establishing the conceptual foundation for the least restrictive alternative doctrine and its derivative theory-community-

But see infra note 188 (referencing several cases where the courts have taken less restrictive alternative requirements seriously).

As long as community mental health services remain underfunded and understaffed, risk-averse mental health professionals and courts will continue committing the not-so-dangerous mentally ill, despite statutory requirements to the contrary.

${ }^{64}$ See LA FOND \& DURHAM, supra note 11, at 147. Some place the current figure of inpatient episodes at 3 million, $60 \%$ more than typically reported in the literature. See Charles A. Kiesler \& AMY E. SibUlkin, Mental Hospttalization: MYTHS AND FACTS ABOUT A NATIONAL CRISIS 272 (1987).

${ }^{65}$ LA FOND \& DURHAM, supra note 11, at 147 . La Fond and Durham also point to an increase in the number of juveniles being placed in institutions. See id. at 115; see also Lois A. Weithorn, Mental Hospitalization of Troublesome Youth: An Analysis of Skyrocketing Admission Rates, 40 STAN. L. REV. 773 (1988).

Because Washington state has been researched extensively on this issue, while other states have not been similarly researched, numbers are not yet available for each state. Nonetheless, as discussed earlier, see supra note 46 , the number of inpatient episodes has increased dramatically over the past several years. Moreover, the logic of expanding the criteria for civil commitment dictates that inpatient episodes will continue to increase. See infra notes $182-83$ and accompanying text (noting increased use of the "gravely disabled" standard for justifying parens patriae commitments). 
based treatment. Once the terms are defined, we will explore in depth the policy arguments that suggest that community-based treatment is not only morally superior to institutionalization, but also clinically and economically superior.

\section{Community-Based Treatment and the Policy ARGUMENTS FAVORING IT}

\section{A. The Concept of Least Restrictive Alternatives: Three Progressions}

The least restrictive alternative doctrine has enjoyed a "rich and varied history. ${ }^{n 6}$ Used by courts in negative commerce, due process, and equal protection clause cases, as well as by federal and state legislators, its genesis can be traced to the case of Shelton $v$. Tucker. ${ }^{67}$ In Shelton, the Supreme Court held, inter alia, that

even though the governmental purpose be legitimate and substantial, that purpose cannot be pursued by means that broadly stifle fundamental personal liberties when the end can be more narrowly achieved. The breadth of legislative abridgement must be viewed in the light of less drastic means for achieving the same basic purpose. ${ }^{68}$

Soon, the least restrictive alternative doctrine began to gain ascendancy in the context of mental health law, finding expression both in state and federal statutory provisions as well as in lower federal court opinions. ${ }^{69}$

The most commonly recognized expression of the doctrine in the mental health context has involved requiring states to provide individuals with the least restrictive type of treatment within the

${ }^{66} \mathrm{P}$. Browning Hoffman \& Lawrence L. Foust, Least Restrictive Treatment of the Mentally Ill: A Doctrine in Search of Its Senses, 14 SAN DiEgo L. REv. 1100, $1101 \mathrm{n} .1$ (1977); see also Schwartz \& Costanzo, supra note 58, at 1350-51 (summarizing the history of the usage of the least restrictive alternative doctrine).

${ }^{67} 364$ U.S. 479 (1960) (holding unconstitutionally overbroad a state statute requiring public school teachers to divulge the names of organizational associations to which they belonged).

${ }^{68}$ Id. at 488 (footnotes omitted).

${ }^{69}$ One of the clearest examples of its use by federal courts in the context of mental health litigation was in Lake v. Cameron, 364 F.2d 657, 661 (D.C. Cir. 1966). See infra text accompanying notes 74-78. As for state statutes, consider South Dakota's definition of the Least Restrictive Alternative Doctrine: "[T]reatment and conditions of treatment which ... are no more intrusive or restrictive of mental, social, or physical freedom than necessary to achieve a reasonably adequate therapeutic benefit." S.D. CoDIFIED LAws $\$ 27 A-1-1(11)$ (1992). 
institution. Based on the notion that states cannot commit individuals in order to treat them and then not provide the treatment, this use of the doctrine has enjoyed great success. In Covington v. Harris, ${ }^{70}$ for instance, the District of Columbia Circuit Court of Appeals, in extending the concept of least restrictive alternatives to treatment decisions made during involuntary hospitalization, held that " [i]t ma[de] little sense to guard zealously against the possibility of unwarranted deprivations prior to hospitalization, only to abandon the watch once the patient disappears behind hospital doors."71 Similarly in Rouse $v$. Cameron, ${ }^{72}$ the same court validated the petitioner's claim that continued commitment at St. Elizabeth's Hospital could not be justified without some form of adequate treatment being provided. ${ }^{73}$

At work in these cases is a form of quid pro quo: "We take your liberty away, but promise to treat you so as to expand your capacity for liberty in the future." Limited conceptually to only those whose liberty has already been infringed, this approach could not faithfully be extended to preserving the rights of those who are "at risk" of being civilly committed or recommitted.

Another approach to the least restrictive alternative doctrine has required state trial courts to consider alternatives to hospitalization before institutionalizing the mentally ill. This concept was clearly enunciated in Lake v. Cameron. ${ }^{74}$ In Lake, a nondangerous, mentally retarded woman sought on statutory grounds to have the committing trial court consider less restrictive alternatives before committing her to St. Elizabeth's Hospital. Finding for the plaintiff, Chief Judge Bazelon of the District of Columbia Circuit instructed the trial court to make "an earnest effort . . . to review and exhaust available resources of the community."75

${ }^{70} 419$ F.2d 617 (D.C. Cir. 1969).

${ }^{71} I d$. at $623-24$.

72373 F.2d 451 (D.C. Cir 1966).

${ }^{73}$ See id. at $452-53$.

74 See 364 F.2d 657 (D.C. Cir. 1966). In Dixon v. Weinberger, 405 F. Supp. 974 (D.D.C. 1975), this concept was applied to those who were already institutionalized, but sought release. The court held that pursuant to the District of Columbia Code, the city needed to make a bona fide effort to consider alternatives to commitment for those who were inappropriately committed. The court also went so far as to require the city to draw up plans outlining how it was going to satisfy its statutory duties. See id. at 977,980 . The court noted that "[i]n the estimation of the Hospital's clinical staff, approximately $43 \%$ of these inpatients currently require care and treatment in alternative facilities." Id. at 976.

${ }^{75}$ Lake, 364 F.2d at 660; see also MONT. CODE ANN. §53-21-101(2), (3) (1991) 
What Chief Judge Bazelon did not do, however, is equally important. He refused to decide whether the District of Columbia would be required to construct community-based alternatives should none be found available. ${ }^{76}$ By reserving judgment to some future date, Chief Judge Bazelon effectively "emasculated" the doctrine. ${ }^{77}$ As discussed earlier, Ms. Lake spent the remaining five years of her life locked away at St. Elizabeth's Hospital simply because no less restrictive alternatives were "available."

A third approach, the one proposed here, is to do what Chief Judge Bazelon did not do: obligate the states to develop community-based services that are "appropriate." This argument is founded on the reality that too often mental health professionals decide where to place individuals on the basis of what is available, not on the basis of what is most appropriate. A standard of appropriateness would require states to expend money to bring their community facilities up to the professional standards currently in vogue. Falling somewhere between the extremes of allowing states to rely on the status quo of "availability" and requiring them to expend unlimited resources for programs that are only "imaginable," the "appropriate" standard would require states to develop communitybased alternatives at a realistic pace determined by professional norms. Although one federal district court, ${ }^{79}$ and a handful of state courts, ${ }^{80}$ have ordered legislatures to fund and develop mental health services in the community, these cases have, with one

(providing that one can be institutionalized "only when less restrictive alternatives are unavailable or inadequate").

${ }^{76}$ See Lake, 364 F.2d at 662.

77 See Eric D. Paulsrud, The Least Restrictive Alternative: A Theory of Justice for the Mentally Retarded, 10 U. ARK. LITTLE ROCK L.J. 465, 491 (1987). The court in Dixon did require that such facilities be made, but it limited its decision to those who were already institutionalized, refusing to extend the statutory obligation to those not yet institutionalized. See Dixon, 405 F. Supp. at 980 . Moreover, to date, these facilities and services have not been created. See Goldstein, supra note 17, at A1 (reporting that a federal judge had appointed a special master to oversee implementation of the decision in May 1993).

${ }^{78}$ See supra note 42 and accompanying text.

${ }^{79}$ See Dixon, $405 \mathrm{~F}$. Supp. at 980 (finding a statutory right to less restrictive treatment for those who were determined to be inappropriately committed at St. Elizabeth's Hospital); see also infra note 163 and accompanying text.

${ }^{80}$ See Arnold v. Arizona Dep't of Health Servs., 775 P.2d 521, 522 (Ariz. 1989) (en banc) (ordering the state to establish residential treatment programs for the mentally ill, but explicitly refusing to address what would happen if the legislature failed to fund such programs); In re D.E.R., 455 N.W.2d 239, 241-43 (Wis. 1990) (ordering the county to place appellant in community-based treatment program under state law, despite claims by the county that it lacked the funds). 
exception, concerned the rights of those currently institutionalized. ${ }^{81}$ This Comment calls for the extension of this right to those who are "at risk" ${ }^{82}$ of being institutionalized for the first time or "at risk" of being recommitted. As will be shown later, ${ }^{83}$ support for this conception of the least restrictive alternative doctrine can be found in state constitutions.

In practice, "appropriate" community-based care would include a full continuum of services: "medications, case management, day treatment, crisis stabilization, transportation, residential services, work adjustment, socialization, recreation, outreach, and mobile crises services. ${ }^{74}$ Taken together, community-based services such as these are most effective when their focus is rehabilitative, that is, when the emphasis is on developing the skills necessary to maintain self-sufficiency and independent functioning in the community. ${ }^{85}$ A full continuum of services-properly coordinated with the social services system as a whole, ${ }^{86}$ and offering various types of treatments for the particularized needs of the mentally ill $^{87}$-would ensure that the mentally ill not only receive treatment in the community, but remain there as well. Although not all forms of community care are of equal value, they all exceed whatever benefits civil commitment provides. ${ }^{88}$

${ }^{81}$ See Amold, 775 P.2d at 529-34 (holding that under Arizona statutory law, the mentally ill were entitled to have the state fund the creation of community mental health services, unrelated to whether any of these individuals were previously institutionalized or not); see also Jose M. Santiago et al., Changing a State Mental Health System Through Litigation: The Arizona Experiment, 143 AM. J. PSYCHIATRY 1575, 1578 (1986) (noting that Arnold's predecessor was the first case in the country in which the plaintiff's successfully established a legal right to receive community mental health services).

82 See supra note 23.

${ }^{83}$ See infra part V.

${ }^{84}$ Amold, $775 \mathrm{P} .2 \mathrm{~d}$ at 524 . For some novel forms of mental health services, consider Hawaii's "Employment Program for the Chronically Mentally Ill," providing community-based employment opportunities for the chronically mentally ill through education, placement, and even housing services, see HAW. REV. STAT. § 334-3.5 (Supp. 1992), and Minnesota and Texas's provision of case managers to assist those released into the community. See MINN. STAT. ANN. $\$ 253$ B. 093 subd. 2 (West Supp. 1993); TEX. HEALTH \& SAFETY CODE ANN. § 534.053(b) (West 1992).

${ }^{85}$ See infra notes 104-07, 133 and accompanying text. Several states have, at least statutorily, recognized the importance of this rehabilitative aspect of mental health care. See, e.g., CAL. WELF. \& INST. CoDE §§ 5670.5, 5671 (West Supp. 1993); HAW. REV. STAT. § 334-102 (1985).

${ }^{86}$ See id.

${ }^{87}$ See, e.g., IND. CODE ANN. § 12-22-2-3 (West Supp. 1992); ORLA. STAT. ANN. tit. 43A, § 5-403i (West 1990 \& Supp. 1993); R.I. GEN. LAWS § 40.1-5-8(10) (1990); TEX. HEALTH \& SAFETY CODE ANN. \$ 534.053(a)(1)-(7) (West 1992).

${ }^{88}$ This is not to say that civil commitment is never an appropriate option. In fact, 


\section{B. Social Benefits}

The most obvious social benefit that can be attributed to community-based treatment is increased liberty. Conversely, it is beyond dispute that the deprivation of liberty associated with civil commitment is one of the most serious infringements on individual autonomy that a state may impose. If society is going to accept this infringement, it should only be imposed with good reason. As will be shown, the reasons generally offered fail to satisfy even cursory examination.

\section{Avoiding Unnecessary Civil Commitments}

Involuntary commitment rests on several faulty assumptions regarding the abilities and activities of the mentally ill. For example, most civil commitments are justified on the mistaken belief that the mentally ill are incapable of reasoning, ${ }^{89}$ incapable of controlling their behavior, ${ }^{90}$ or incapable of knowing what they want or what is in their best interests. ${ }^{91}$ Community-based treatment is thus seen as not providing enough control and guidance for the mentally ill. As proof for this proposition, many point to the

for many of the severely, chronically mentally ill who are dangerous to themselves or to the public, civil commitment may be the best forum for their needs. What community-based alternatives provide, however, is a choice-a choice that both mental health professionals and the courts are compelled to consider to ensure treatment in the least restrictive, and yet most "appropriate," setting.

${ }^{89}$ See Morse, supra note 39 , at 60 n.25.

${ }^{90}$ As Morse notes, the only difference between a "hot tempered patient," who threatens a doctor, and the "delusional patient," who fears his doctor, is that one can be civilly committed and the other cannot, even though "no conclusive means" exist to prove that one has greater or lesser control than the other. Id. at 61. Morse concludes that there exists little support for an involuntary commitment system that is imposed only on the mentally disordered. See id. at 66 .

${ }^{91}$ See Stromberg \& Stone, supra note 32, at 334 (recognizing that "many mental disorders do not impair a person's ability to assess her desire for hospitalization or a particular therapy"). Moreover, many researchers have noted that when it does come to preferences, the mentally ill prefer treatment in the community to treatment in state-run hospitals. See Robert L. Okin, Patients' Perceptions of Their Quality of Life 11 years After Discharge from a State Hospital, 44 HOSP. \& COMMUNITY PSYCHIATRY 236, 239 (1993) (concluding that "patients with serious and chronic mental illness who are placed in well-staffed community programs perceive this change to be a genuine improvement in the quality of their lives," and that their preference for community life persists over a long period of time); Mark Olfson, Assertive Community Treatment: An Evaluation of the Experimental Evidence, 41 HOSP. \& COMMUNTTY PSYCHIATRY 634, 640 (1990) (noting that based on studies done on the Training in Community Living program in Madison, Wisconsin, patients consistently "prefer community-based treatments to traditional hospital-based care"). 
homeless mentally ill who are deemed absolutely crazy for "wanting" to brave the natural and man-made challenges of life on the street. ${ }^{92}$ But as some researchers believe, the indices of behavioral disturbance are often conflated with those most commonly associated with homelessness (for example, dirty clothes and poor hygiene). ${ }^{93}$ As a result, some of the homeless mentally ill are institutionalized on the mistaken belief that their actions (remaining homeless and avoiding shelters) reflect an impaired ability to do what is in their best interests. ${ }^{94}$

At the heart of the state's police power lies yet another mistaken assumption: "Mental disorder is both an over and underinclusive predictor of dangerousness; most crazy persons are not dangerous and many normal persons are. ${ }^{n 5}$ Since fears abound regarding the homeless, and statutes associate the likelihood of harm with "deterioration," the threat of overinclusive commitments is severe. $^{96}$ Even back in 1975, when concern for the civil rights of the mentally ill was at an all time high, ${ }^{97}$ fully $90 \%$ of those compulsorily detained in mental institutions were not sufficiently dangerous to warrant hospitalization. ${ }^{98}$

92 See supra note 57.

${ }^{93}$ See Kaufman, supra note 57, at 362.

94 See id. at 364 (noting that many of the homeless living in the streets "may actually be making a rational 'choice' when shelter is available but unsafe").

${ }^{95}$ Morse, supra note 39, at 62.

${ }^{96}$ As one frustrated jurist has noted, the conditions of the homeless can be explained in many different ways:

[T] he homeless are generally unkempt, dirty, poorly clad, and often reek of urine and feces, yet respondents expressly deny that the mere condition of being homeless and malodorous makes a person dangerous to himself. . . .

Petitioner's conduct on the street is understandable if we appreciate her obvious pride in her independence and in her ability to survive on her own. She derives a unique sense of success and accomplishment in her street life.

Boggs v. New York City Health \& Hosps. Corp., 523 N.Y.S.2d 71, 92-94 (App. Div. 1987) (Milonas, J., dissenting), appeal dismissed, 525 N.Y.S.2d 796 (1988).

${ }^{97}$ See supra text accompanying notes $39-40$.

${ }^{98}$ See Michael L. Perlin, State Constitutions and Statutes as Sources of Rights for the Mentally Disabled: The Last Frontier?, 20 LOY. L.A. L. REV. 1249, 1253 n.22 (1987); see also O'Connor v. Donaldson, 422 U.S. 563,576(1975) (detailing the criteria necessary to civilly commit, and holding that "a State cannot constitutionally confine without more a nondangerous individual who is capable of surviving safely in freedom by himself or with the help of willing and responsible family members or friends"). Kaufman points out that too many are institutionalized because psychiatrists overpredict out of fear of "professional and litigious charges of incompetence," and that "mental health professionals are predisposed to provid[ing] mental health care 
As is the case with defining "capacity," defining who is or is not dangerous escapes scientific certitude. ${ }^{99}$ Ultimately, the criteria depend on political and moral conceptions. In the 1980 s, for instance, deciding who was committable reflected an expanded notion of dangerousness and ultimately resulted in increased commitment. ${ }^{100}$ Given the imprecision and malleability of these standards, one can only assume that many of the institutionalized have been unnecessarily, and in some cases arbitrarily, deprived of their liberty. Moreover, because legal and medical liability have encouraged mental health professionals to err on the side of overcommitment, ${ }^{101}$ many individuals have been unnecessarily committed for this reason as well. ${ }^{102}$ Although new and improved legal norms could provide more guidance, risk-averse mental health professionals will likely continue to choose commitment unless and until the states create and adequately fund effective communitybased treatment centers. ${ }^{103}$

and are less inclined to safeguard liberty rights." Kaufman, supra note 57, at 361 .

${ }^{99}$ See Jur Strobos, The Constitution and the Rights of the Mentally $M l l, 10 \mathrm{~J}$. LEGAL MED. 661, 661 (1989) (noting that "imminent harm' defies logical explanation as it is irrelevant to professionally accepted" indices of mental illness); see also Heller v. Doe, 113 S. Ct. 2637, 2644 (1993) (upholding Kentucky's higher burden of proof standard for commitment of the mentally ill than for the mentally retarded because 'Kentucky's basic premise that mental retardation is easier to diagnose than is mental illness has a sufficient basis in fact"); Elizabeth Rosenthal, Who Will Turn Violent? Hospitals Have to Guess, N.Y. TIMES, Apr. 7, 1993, at A1 (noting that "predictions about who will be violent are often made on the basis of limited information, and even more limited science, leading to a sometimes mediocre batting average").

${ }^{100}$ See BRAKEL ET AL., supra note 30, at 36 n.132. Brakel also notes that "[s]tudies of mentally disabled persons, though not uncontroverted, have tried to show that as a group they are no more dangerous than the general population and, moreover, that identifying those few who are likely to do harm is a task to which the medical profession is demonstrably not equal." $Y d$. at 25 (footnote omitted).

${ }^{101}$ Despite the clear benefits of community care, hospitalization is still popular among clinicians, see Keilitz et al., supra note 9, at 703, in part because most clinicians were trained in an era when hospitalization was seen as the best place to treat the mentally ill. See John A. Talbott \& Ira D. Glick, The Inpatient Care of the Chronically Mentally $I l, 12$ SCHIZOPHRENIA BULL. 129, 130 (1986). Another reason for the popularity of hospitalization stems from judges who fear releasing mentally ill patients into the community because they may later harm someone. See Chambers, supra note 18 , at 1122-23.

${ }^{102}$ See Morse, supra note 39 , at 67-69.

${ }^{103}$ Evidence exists to suggest that mental health professionals determine that community alternatives are inappropriate because they are not available not because they are inappropriate. See Seicshnaydre, supra note 43, at 1983-84; see also Jackson v. Fort Stanton Hosp. \& Training Sch., 964 F.2d 980, 992 (10th Cir. 1992) (upholding considerations of community service availability when placement decisions are being made). By conforming their recommendations to perceived financial constraints, 


\section{Receiving Effective Liberty-Enhancing Treatment}

In addition to the obvious freedom from restraint, community programs provide yet another liberty dimension-liberty to develop and maintain the skills necessary to exercise freedom. ${ }^{104}$ Although one may no longer be caged in by walls, one may still be constrained by one's own deficiencies. Community treatment, unlike civil commitment, enables the mentally ill to adjust to their real world surroundings and develop the skills needed to live autonomous lives with dignity. ${ }^{105}$ Therefore, a less obvious, though no less important, benefit of community-based treatment is its prophylactic qualities: "Providing appropriate treatment and support services in the community will substantially reduce the risk of confinement in an institution ...."106 Not only will those never-before institutionalized be less likely to find themselves committed, but, for those who have been institutionalized, wellcoordinated and sufficiently funded community services may stop the door from revolving. ${ }^{107}$

On the other hand, civil commitment, even under the best of conditions, is not likely to "cure' more than a handful of those committed of their deviant behavior. ${ }^{108}$ The fact that very few

mental health professionals are not only exceeding their role, but are also validating the status quo. See Kiesler, supra note 46, at 359 (arguing that deference to professionals "lead[s] to excessive hospitalization"). In Dixon v. Weinberger, $405 \mathrm{~F}$. Supp. 974 (D.D.C. 1975), the court noted that St. Elizabeth's own clinical staff had conceded that $43 \%$ of its inpatients could be treated in alternative facilities, but that such facilities still did not yet exist. See id. at 976. Without these community alternatives in place, risk-averse health professionals will continue to choose commitment.

${ }^{104}$ See Costello \& Preis, supra note 11, at 1541.

${ }^{105}$ See Clark v. Cohen, 794 F.2d 79, 96 (3d Cir. 1986) (Becker, J., concurring) ("Liberty is more than merely the absence of physical confinement; as the Supreme Court's privacy cases make clear, the right of liberty is a right to personal autonomy."), cert. denied, 479 U.S. 962 (1986).

${ }^{106}$ Costello \& Preis, supra note 11, at 1533; see also LA FOND \& DURHAM, supra note 11, at 90 ("In enacting [much of its progressive mental health legislation in the 1960s] Congress assumed that, in many cases, mental illness could be prevented by early treatment in the community ....").

Conversely, "[s]eparation ... impedes reintegration into community life." Chambers, supra note 18, at 1113 (noting that isolation breeds further "withdrawal and deterioration"). Chambers also refers to one incident where a patient, long hospitalized, made a visit outside the hospital, and "literally could no[t] . . bring himself to choose what he would have for lunch." Id. at 1128.

${ }^{107}$ See supra note 46 and accompanying text.

${ }^{108}$ Morse, supra note 39, at 80 . With the help of accreditation committees, which have demanded that mental institutions maintain high standards, and a vigilant press, conditions in mental institutions have improved somewhat. See BRAKEL ET AL., supra 
psychiatrists desire to practice in public or private mental institutions sheds light on the quality of the clinical treatment received by the mentally ill in those settings. ${ }^{109}$ What is arguably most troubling about the ineffectiveness of civil commitment, however, is that very few of the institutionalized ever learn how to adjust to living outside the institution. ${ }^{110}$ In fact, involuntary hospitalization may actually make people less capable of living in the community. ${ }^{111}$ If this is true, the promise of institutionalization-as a place for treatment and normalization-does nothing but "propagate a cruel myth."112

\section{Eliminating the Stigma Through Interaction}

Community treatment also serves to educate. Although the presence of the mentally ill in communities often arouses anxiety, ${ }^{113}$ the overuse of civil commitment stigmatizes mentally ill individuals, fueling and sanctioning well-developed stereotypes and prejudices. ${ }^{114}$ Moreover, the cycle of periodic releases and recom-

note 30 , at 337 (noting that "[w] hile most mental institutions today are providing far better care and treatment than they did a decade or two ago, the baseline from which progress is measured is very lown $)$; see also Chambers, supra note 18 , at $1125-26$ (noting that hospitals used to be understaffed, overcrowded, and in physical decay and that many hospital staff members were foreigners who had inadequate training and who often did not speak English); Ronald K.L. Collins, Reliance on State Law: Protecting the Rights of People with Mental Disabilities, 13 VT. L. REV. 305, 309 (1988) (detailing "warehouse"-like conditions at Willowbrook, a large state-run mental health facility).

${ }^{109}$ See BRAKEL ET AL., supra note 30, at 47 ("The number of fully licensed psychiatrists willing to work in public facilities remains well below the need for them."); LA FOND \& DURHAM, supra note 11, at 85 (stating that "[i]n 1948 approximately one-half of all psychiatrists were employed full time in state mental hospitals," but, "[b]y the mid- 1960 s . . . only 14 percent were practicing in public or private hospitals"). In South Dakota, five mental health centers currently share a single psychiatrist, and, in many other rural areas, community services have no psychiatric professionals. See Torrey, supra note 5, at 24 (noting that federal requirements ensuring that mental health professionals work in the public service for a period of time were not implemented until 1981, following a marked reduction of training funds).

${ }^{110}$ See Kiesler, supra note 46, at 350 (noting that institutionalization fosters unstitutional dependency in various ways, leading over time to [the] progressive loss of social and vocational competencies").

111 See KIESLER \& SIBULKIN, supra note 64, at 163.

112 Morse, supra note 39 , at 84 .

11 See Strobos, supra note 99, at 666 (noting that people's fears of the mentally ill are often irrational and pointing out that some believe that mental illness is contagious).

${ }^{114}$ See Christopher Slobogin, Treatment of the Mentally Disabled: Rethinking the 
mitments interferes not only with the developmental growth and normalization of the mentally ill, but also with the community's ability to accept them. Meaningful community involvement over an extended period of time would help dispel fears through understanding, and thereby, protect the rights of thousands of mentally ill and homeless people currently threatened with commitment. As John Hart Ely noted in his general discussion of discrete and insular minorities:

Increased social intercourse is likely not only to diminish the hostility that often accompanies unfamiliarity, but also to rein somewhat our tendency to stereotype in ways that exaggerate the superiority of those groups to which we belong. The more we get to know people who are different in some ways, the more we will begin to appreciate the ways in which they are not .... .115

\section{Economic Benefits}

Several well-respected, oft-cited studies suggest that community care is cheaper than institutionalization, and yet equally, if not more, effective. ${ }^{116}$ One of the most influential books on the relative costs of community treatment and mental hospitalization is Kiesler and Sibulkin's Mental Hospitalization. ${ }^{117}$ The book reviewed fourteen studies in which serious psychiatric patients were randomly assigned to either inpatient or some alternative mode of outpatient care. Kiesler and Sibulkin determined that "the most general conclusion one can draw from [these studies] is that

Community-First Idea, 69 NEB. L. REV. 413, 419 (1990) (noting how group integration can facilitate acceptance of mentally disabled people).

115 JOHN H. ELY, DEMOCRACY AND DISTRUST 161 (1980).

${ }^{116}$ See KIESLER \& SIBULKIN, supra note 64, at 169 (reviewing 14 studies in which serious psychiatric patients were randomly assigned to inpatient or outpatient settings). Michael Perlin also concluded that "an ample, largely uncontradicted but regularly ignored body of evidence . . . indicates that a well-conceived deinstitutionalization program ... has a positive and significant effect on the length of the expatients' 'tenure' in the community." Perlin, supra note 11, at 89 . Moreover, there does not appear to be any data that "support[s] ... hospitalization instead of outpatient alternatives for most of [the mentally ill]." Talbott \& Glick, supra note 101, at 130 (referring to the chronic schizophrenic and noting further that "there is a consistent conclusion that alternative care is as, if not more, effective than inpatient treatment in reducing symptomatology, rehospitalization, interpersonal difficulties, and vocational disablement" (citations omitted)); see also Kiesler, supra note 46, at 357 (noting that "[i]n no case did the cost of alternative care exceed that of inpatient care" while at the same time arguing that "[t]here is not an instance . . . in which hospitalization had any positive impact ... which exceeded that of alternate care").

${ }^{117}$ KIESLER \& SIBULKIN, supra note 64, at 179. 
alternative care is more effective and less costly than mental hospitalization." 118 In fact, regardless of the outpatient setting used, ${ }^{119}$ the outcome indices by which their effectiveness is measured, ${ }^{120}$ or the patient population using them, ${ }^{121}$ alternative care programs have universally provided more positive results more cheaply than institutionalization.

Conversely, operating mental institutions has become exceedingly costly and not nearly as effective in treating the needs of the mentally ill. ${ }^{122}$ Higher accreditation standards, ${ }^{123}$ public employee union demands, ${ }^{124}$ and labor intensive functions, such as supervision and security, have contributed to escalating costs for state-run institutions. This, in an age of fiscal conservatism, has rendered the maintenance and expansion of mental institutions very difficult.

Since "[a]lmost all mental health treatment . . . available can be provided as efficaciously and usually more cheaply in less restrictive

118 Id. at 179.

${ }^{119} \mathrm{See}$ id. at 158-59 (noting more positive results regardless of whether the individuals were treated in hostels, day care centers, or total community care programs).

${ }^{120}$ See id. at 172 (listing psychopathology, employment opportunities, and independence as some of the indices).

${ }^{121}$ See id. at 173.

122 "In 1974 the annual average cost of care for a patient in a public mental hospital was $\$ 11,250$," whereas, the annual average cost for outpatient care was only \$531. LA FOND \& DURHAM, supra note 11, at 89. Today in New York, the state pays $\$ 105,000$ per person per year, or a total of $\$ 1.23$ billion for individuals in institutions; whereas only $\$ 482$ million is allotted for the more than 150,000 people treated in the community. See Richardson, supra note 10, at B7 (discussing the politics of hospital expenditures); Verhovek, supra note 19 , at 1 (noting how the state spends $\$ 2.9$ million a year to take care of 14 mentally ill patients in one psychiatric hospital). While the costs associated with providing "effective" outpatient treatment will likely narrow this gap, the majority of the studies have determined that compared to institutionalization, effective (actually more effective) alternative care programs are less costly.

${ }^{123}$ See Mark J. Seling \& Gary W. Johnson, A Bridge to the Community for ExtendedCare State Hospital Patients, 41 HOSP. \& COMMUNITY PsychIATRY 180, 180 (1990). Ironically, the liberalizing efforts of those who sought to upgrade the conditions of mental institutions also contributed to rising costs. Naturally, with increased costs for personnel and upkeep, the expected savings from reduced patient loads never materialized. Likewise, the deinstitutionalization dividend that was expected to fund community-based services never appeared. See LA FOND \& DURHAM, supra note 11, at 88, 110-11; Seicshnaydre, supra note 43, at 1974 (noting that many advocates of the mentally disabled point to the funneling of funds into institutions for why conditions in the community are so bad).

${ }^{124}$ The unionization of hospital labor resulted in "[e]ight-hour work days and forty-hour workweeks doubl[ing] the unit cost of state hospital care." LA FOND \& DURHAM, supra note 11, at 88. 
community settings than in closed hospitals, 125 why then have states, as fiscally constrained as they are, not switched? Although politics ${ }^{126}$ has been the major factor, economics have ironically played a role as well. Per patient, the costs for effective community treatment are certainly less than the costs of civil commitment. ${ }^{127}$ But since community treatment is premised on more individuals receiving adequate care, total short run costs may actually exceed current mental health expenditures. ${ }^{128}$ Not only would these programs be catering to larger numbers-particularly the chronically

${ }^{125}$ Morse, supra note 39 , at 84.

${ }^{126}$ See Ludwig, supra note 16, at 1092 ("State hospitals were political fiefdoms. Shutting down a state hospital was not much different from trying to close a military base or a naval shipyard.").

${ }^{127}$ In a study completed two years after Kiesler and Sibulkin's, the researchers concluded that:

Compared with inpatient state hospital treatment for chronic mentally ill subjects, an intensive residential treatment program was able to achieve comparable results in a shorter period of time, with greater cost efficiency, and with less rehospitalization of patients after discharge from the index treatment. These comparisons validate the clinical and economic value of this highly structured program.

Jeffrey Bedell \& John C. Ward, An Intensive Community-Based Treatment Alternative to State Hospitalization, 40 HOSP. \& COMMUNTTY PSYCHIATRY 533, 535 (1989). The treatment provided in this study included 14 hours of psychoeducational activities, focused primarily upon the development of social skills. See id. at 533. Although the daily cost per patient in the intensive residential treatment unit was almost $\$ 40$ more than in the state hospital, the average overall cost per patient in the community program was $\$ 9152$ less. See id. at 534 . The discrepancy in these figures was due to the fact that the average hospital patient spent 165 days in the mental wards, as compared with 35 days for patients treated in the community. See id.; see also Kiesler, supra note 46 , at 358 (pointing out that the mentally ill "could be treated in alternative settings more effectively and less expensively").

${ }^{128}$ See Morse, supra note 39, at $87 \mathrm{n} .144$ (noting that increased costs will be generated not by "the high costs per patient of community treatment compared to hospitalization," but "the increase would be the result of providing adequate treatment to vastly greater numbers of persons"); see also Carl A. Taube et al., New Directions in Research on Assertive Community Treatment, 41 HOSP. \& COMMUNITY PSYCHIATRY 642, 642 (1990) (noting that assertive community treatment programs tend to cost more than traditional outpatient care, but these programs appear to be more "cost-effective alternatives to traditional hospital and aftercare programs"). But see TORREY, supra note 17, at 205 (arguing that the public funds spent on the mentally ill in 1985 would "probably [be] sufficient to provide excellent care of the seriously mentally ill if the money is used wisely"); Celia W. Dugger, Albany Accord Supports Clinics for Mentally Ill, N.Y. TIMES, Nov. 17, 1993, at A1, B4 (reporting that the Governor of New York and the Chairmen of the Senate and House Committees of the State legislature had agreed to a mental health bill that would take $\$ 210$ million in projected savings from the closing of five mental hospitals and place the funds into services for the mentally ill in the community, increasing the state's spending on community mental health services by $20-25 \%$ ). 
mentally ill, but states would also be required to develop and staff $^{129}$ the programs. The long-term benefits and cost-savings of such an approach, however, are numerous. As already mentioned, community treatment is a "prophylactic," reducing the need for future hospitalization and thus preserving individual liberty. ${ }^{130} \mathrm{~A}$ form of preventative medicine, community-based treatment also offers an economic boon. In an age of skyrocketing health care costs, reformers are increasingly calling for preventative approaches to health care. ${ }^{131}$ By most accounts, preventing illness is more cost-effective than treating illness. ${ }^{132}$ So too with mental illness. A strategy of mental health that is directed towards identifying and treating those "at risk" would be in the vanguard of modern health care reform.

Additionally, for those who are or have been institutionalized, well-funded, coordinated, community-based services would ensure that the chronically mentally ill could leave the institutions permanently. With effective community-based health services, fewer numbers of mentally ill patients fall through the cracks, and many more actually have a chance at normalization. ${ }^{133}$ Not only does

${ }^{129}$ A few commentators have suggested that medical school residents training for a career in psychiatry be given incentives to work in public mental health facilities. This innovation could presumably include working in community treatment centers and outpatient clinics. See LA FOND \& DURHAM, supra note 11, at 161 (stating that because "America heavily subsidizes the training of thousands of psychiatric residents each year," the country "deserve[s] a modicum of public service from them in return"); Torrey, supra note 5, at 25 (calling for an "automatic one-year-for-one-year payback obligation attached to all state-funded training programs" for psychiatrists).

${ }^{130}$ See Slobogin, supra note 114, at 431 (noting that the rationale behind group integration is to allow "the mentally disabled [to] become familiar to and interact with the rest of society [such that] they have [a] chance at successful assimilation into the community"); supra notes 104-07 and accompanying text.

${ }^{131}$ See Hawaii Health Care Is Called a Model for U.S., N.Y. Times, May 19, 1993, at A13 [hereinafter Hawaii Health Care] (noting that heal th care costs were relatively low in Hawaii where the health care system emphasizes prevention and early treatment); Spencer Rich, Administration to Provide Free Vaccines for Children, WASH. POST, Apr. 1 , 1993, at A14 (noting that "[e]mphasizing vaccination is in accord with the administration's focus on preventive health care").

${ }^{132}$ See Hawaii Health Care, supra note 131, at A13.

133 For example, in New Jersey, the 450 Plan (designed to deinstitutionalize 450 mental patients) has successfully assisted formerly committed patients adjust to living in the community. See Jacqueline Shaheen, Helping the Mentally Ill Rejoin the Community, N.Y. TIMES, May 23, 1993, § 13, at 1; see also José D. Arana et al., Continuous Care Teams in Intensive Outpatient Treatment of Chronic Mentally Ill Patients, 42 HOSP. \& COMMUNITY PSYCHIATRY 503, 503 (1991) (noting that 32 of 39 patients treated in an intensive outpatient treatment program experienced "increased rates of treatment compliance, decreased frequency of crises, and decreased frequency and 
this improve their potential for successful treatment, ${ }^{134}$ but perceptions of the mentally ill in the community improve as well. ${ }^{135}$ No longer is re-institutionalization discussed as a solution for our homeless population; ${ }^{136}$ instead, the creation of community services addresses the problems of the portion of the homeless population that is mentally ill. As for the majority of the homeless population that is not, exposing the myth of deinstitutionalization directs our attention to the real cause of homelessness: poverty.

Although community mental health services do exist, ${ }^{137}$ there are no guarantees that policymakers will be persuaded to improve upon and expand their current systems. If, however, a given policy can be shown to be more effective and cheaper than some other alternative, the stage may be set for political reform. What transforms a policy idea into law is the existence of a "window of opportunity." ${ }^{138}$ Although the emergence of eased commitment criteria in recent years seems to indicate that most windows are now

duration of hospitalization"); Alberto B. Santos et al., Providing Assertive Community Treatment for Severely Mentally Ill Patients in a Rural Area, 44 HOSP. \& COMMUNITY PSYCHIATRY 34, 34 (1993) (noting that assertive community treatment programs in rural South Carolina have resulted in a "79 percent decrease in hospital days per year, a 64 percent decrease in the number of admissions per year, a 75 percent decrease in the average length of stay per admission, and a 52 percent reduction in estimated direct cost of care" ).

${ }^{134}$ See supra text accompanying notes 117-21.

${ }^{135}$ See supra text accompanying notes 113-14.

${ }^{136}$ See supra text accompanying notes 52-56.

${ }^{137}$ See Frances L. Randolph et al., Residential Programs for Persons with Severe Mental Illness: A Nationwide Survey of State-Affiliated Agencies, 42 Hosp. \& CoMmuNITY PSYCHIATRY 1111, 1111 (1991) (noting the rapid growth since 1980 in the number of residential programs, most offering only social and recreational activities and medication supervision, and lacking professionally trained mental health program staff).

${ }^{138}$ According to John W. Kingdon's agenda-setting model, political events occur and policies are made when:

[s]olutions become joined to problems, and both of them are joined to favorable political forces. This coupling is most likely when a policy window-an opportunity to push pet proposals or one's conception of problems-is open.

Policy windows are opened either by the appearance of compelling problems or by happenings in the political stream. . . .

... [Meanwhile, policy e]ntrepreneurs who advocate their pet alternatives are responsible for this coupling. They keep their proposal ready, waiting for one of two things to happen: a problem that might float by to which they can attach their solution, or a development in the political stream ... that provides a receptive climate for their proposal.

John W. Kingdon, Agendas, Alternatives, ANd PUblic POlicies 204 (1984). 
closed, other legal sources may provide the catalyst needed to let in the air. ${ }^{139}$

\section{SEARCHING FOR A RIGHT TO COMMUNITY-BASED TREATMENT IN FEDERAL STATUTORY, CONSTITUTIONAL, AND STATE STATUTORY REMEDIES}

The discussion so far has revealed two very distinct pictures. On one hand, the rights of the mentally ill are seriously threatened. As society increasingly equates mental illness with homelessness, the calls for relaxed civil commitment laws become more strident and more difficult to ignore. That several states have already heard the call and acted makes the issue more urgent. On the other hand, these calls for increased commitment face an overwhelming mass of evidence indicating that civil commitment is not only more libertyrestricting, but also less effective, more costly, and, in the long-run, more harmful than other less restrictive approaches to treating the mentally ill.

Assuming one wishes, as this author does, to protect the interests of the mentally ill, the next step must be to understand how the mixed reality of the mentally ill's condition will affect the institutional organs that are traditionally relied on for such protection. Will state legislatures be loath to offer assistance, given the public pressures to do otherwise? Will Congress, elevated somewhat above more localized political pressures, prove a useful source? Or should the courts be turned to for protection of the rights of the mentally ill? And if so, which courts, federal or state? These questions must be asked and the following discussion attempts to answer them.

\section{A. Federal Statutes}

In 1963, Congress passed the Mental Retardation Facilities and Community Mental Health Genters Construction Act (the "Construction Act"). ${ }^{140}$ Designed to create incentives for states to provide health care services in the community, the Construction Act

${ }^{139}$ See Schwartz \& Costanzo, supra note 58, at 1379 (noting that today " $[\mathrm{t}]$ here is an unusual degree of consensus among parties who rarely share common views that the first priority for almost all states should be the development of an adequate array of less restrictive community alternatives").

${ }^{140}$ Pub. L. No. 88-164, 77 Stat. 282 (1963), repealed by Omnibus Budget Reconciliation Act of 1981, Pub. L. No. 97-35, § 902(e)(2)(B), 95 Stat. 560. 
authorized the allocation of money to states that had developed comprehensive mental health plans. Presumably, these comprehensive health plans would cater to both the mentally retarded and the mentally ill. In subsequent years, extending well into the 1970s, Congress maintained its commitment to community-based service development, helping fund over 760 community centers across the country. ${ }^{141}$

In 1981, however, Ronald Reagan convinced Congress to pass his Omnibus Budget Reconciliation Act (the "Omnibus Act"). ${ }^{142}$ The Omnibus Act, created in the spirit of "fiscal federalism"143 that dominated the 1980s, block granted federal funding for mental health services to the states. The result was an aggregate reduction in federal mental health funding for the states, and because of the block granting, proportionately less funding for community mental health centers. ${ }^{144}$ Additionally, Medicaid, Medicare, and SSI policies during the Reagan era limited the incentives for states to develop community mental health centers, further reducing their demand and supply. ${ }^{145}$

Another assistance program, designed to assist the mentally disabled, is the Developmental Disabilities Assistance and Bill of Rights Act ("DD Act"). ${ }^{146}$ Section 6009 of the DD Act provides

${ }^{141}$ See BRAKEL ET AL., supra note 30 , at 626.

${ }^{142}$ Pub. L. No. 97-35, 95 Stat. 357 (1981) (codified as amended in scattered sections of 42 U.S.C.).

143 See generally THOMAS J. ANTON, AMERICAN FEDERALISM AND PUBLIC POLICY 2024 (1989) (discussing the conceptual model of fiscal federalism, by which the federal government devolves responsibility for the implementation and funding of government services onto states and localities).

144 Compounding the problem of reduced federal assistance has been the severe fiscal problems facing many state governments. See Susan B. Hansen, State Fiscal Strategies for the 1990s: Balancing Budgets in a Recession, PUBLIUS, Summer 1991, at 155, 156 (noting that "northeastern and Middle Atlantic states have been hardest hit").

${ }_{145}$ See BRAKEL ET AL., supra note 30, at 675 (discussing how Medicaid has left little money for noninstitutional community-based services); M. Gregg Bloche \& Francine Cournos, Mental Health Policy for the 1990s: Tinkering in the Interstices, $15 \mathrm{~J}$. HeALTH POL. POL'Y \& L. 387, 397 (1990) (discussing cutbacks by the Reagan administration of SSI and SSDI benefits for the chronically mentally ill); William Gronfein, Incentives and Intentions in Mental Health Policy: A Comparison of the Medicaid and Community Mental Health Programs, 26 J. HEALTH \& SOC. POL'y 192, 203 n.10 (1985) (noting that both Medicare and Medicaid are "tilt[ed] away from providing outpatient services to the mentally ill"); Kiesler, supra note 46, at 350 (noting that "[w] hile NIMH supports a national policy of deinstitutionalization and outpatient care, the Medicaid/Medicare programs have incentives favoring hospitalization").

${ }^{146}$ Pub. L. No. 98-527, 98 Stat. 2662 (1984) (codified as amended at 42 U.S.C. $\S \S 6000-6083$ (1988 \& Supp. III 1991)). 
that "[p]ersons with developmental disabilities have a right to appropriate treatment, services, and habilitation for such disabilities." 147 Subsection 2 further requires that treatment "should be provided in the setting that is least restrictive of the person's personal liberty." 148 Invoking the least restrictive alternative language, the DD Act was seen by many as requiring states that received federal assistance to actually create community facilities. ${ }^{149}$ In Pennhurst State School and Hospital v. Halderman ${ }^{150}$ ( ${ }^{\text {Pennhurst }} I$ "), however, the Court, per Justice Rehnquist, noted that "nothing in the Act ... suggest[s] that Congress intended to require the States to assume the high cost of providing 'appropriate treatment' in the 'least restrictive environment.' ${ }^{m 15}$ What was characterized as an aspirational right could not be translated into an affirmative right.

The Americans with Disabilities Act ("ADA"), ${ }^{152}$ passed in 1990 as an antidiscrimination measure, has been cited by at least one student of the Act as yet another possible source for the affirmative right to community-based treatment. ${ }^{153}$ On its face, the ADA prohibits discrimination in public services on the basis of disability. ${ }^{154}$ Its underlying purpose is to reintegrate handicapped individuals into the community by providing them with an opportunity to partake in regular governmental programs or programs geared specifically to their needs. ${ }^{155}$ Some, however, have construed the ADA to place an affirmative obligation on states and localities to "ensure 'meaningful access' to community programs, even for the most disabled." 156

${ }^{147} I d . \S 6009(1)$.

${ }^{148} I d . \S 6009(2)$.

${ }^{149}$ While the law was directed towards the developmentally disabled, and not the mentally ill, the creation of community alternatives would theoretically have benefitted both.

${ }^{150} 451$ U.S. 1 (1981).

151 Id. at 18.

152 Pub. L. No. 101-336, 104 Stat. 327 (1990) (current version at 42 U.S.C. $\$ \S 12101-12213$ (Supp. II 1990 \& Supp. III 1991)).

${ }^{153}$ See Seicshnaydre, supra note 43, at 2000.

154 See 42 U.S.C. \$§ 12131-12165 (Supp. III 1991).

155 See Nondiscrimination on the Basis of Disability in State and Local Government Services, 28 C.F.R. $\$ 35$ (1992).

${ }^{156}$ Seicshnaydre, supra note 43, at 1990 (quoting Jackson v. Fort Stanton Hosp. \& Training Sch., 757 F. Supp. 1243, 1298-99 (D.N.M. 1990), rev'd in part, 964 F.2d 980 (10th Cir. 1992)); see also Timothy M. Cook, The Americans with Disabilities Act: The Move to Integration, 64 TEMP. L.Q. 393 (1991) (discussing generally how the ADA cannot work unless the mentally and physically disabled are actually brought into the 
Upon closer examination, it is unlikely that the ADA would ever fulfill what its advocates believe to be the Act's underlying promise. On its face it incorporates absolutely no language dictating the creation of a positive right. Instead, the language is negative, indicating what Congress and the states cannot do, rather than what they must do. Moreover, to believe that the courts would construe such a document to compel the construction of community facilities for the mentally handicapped ignores the lessons learned from Pennhurst I. The ADA is not geared towards ensuring that those who are mentally ill have community services developed for them; only that those that already do exist be open to them. ${ }^{157}$

The future of congressional action on the mental health care front is likely to be more promising during the Clinton administration. With a Democratic Congress and President concerned generally about health care reform, ${ }^{158}$ the nation may begin to focus its attention on the needs of the mentally ill. ${ }^{159}$ Unfortunately, with the nation's economy as it is, and with most health care reforms directed towards reducing both short-term and long-term costs, the likelihood of Congress and the President authorizing large appropriations for capital construction projects is minimal. Just as unlikely is the prospect of Supreme Court intervention on behalf of the mentally ill.

community, not simply provided an empty right).

${ }^{157}$ See Williams v. Secretary of Executive Office, 609 N.E.2d 447, 453 (Mass. 1993) (holding that "[a]lthough we recognize that deinstitutionalization with subsequent services may be highly desirable for individuals in the plaintiffs' position, such services are not required as a matter of law by the $\mathrm{ADA}^{\prime}$ ); Stephan Haimowitz, Americans with Disabilities Act of 1990: Its Significance for Persons with Mental Illness, 42 HosP. \& COMMUNITY PSYCHIATRY 23, 24 (1991) (noting that while the ADA may protect individual liberty from state action, it does little to ensure the development of community services).

${ }^{158}$ See, e.g, Richard L. Berke, The Health Plan: Rising Expectations and Fear of the Bills Create an Opening, N.Y. TrMes, Sept. $26,1993, \S 4$, at 1 ( ${ }^{\alpha}[\mathrm{N}]$ early 50 years after President Harry S. Truman proposed national health insurance, a consensus has finally emerged among Republicans, Democrats, labor, and business groups that the nation needs to change the system.").

${ }^{159}$ It should be noted, however, that preliminary reports on the probable effects of Clinton's health care package on the mentally ill present a mixed message. See, e.g, Marlene Cimons \& Karen Tumulty, Package Draws Words of Praise, Warning, L.A. TIMES, Sept. 23, 1993, at A12, A13 (noting that " [m]ental health groups cheered the recognition that mental illness should be considered on a par with physical disease but said they were unhappy that full coverage would not be provided until the year 2001"); Irvin D. Rutman, Health-Care Plan Should Include Provision for Mental-Health Services, PHILA. INQUIRER, Sept. 18, 1993, at A11 (editorial page) (expressing concern that Clinton's health care plan will cut back on psychiatric rehabilitation services). 


\section{B. Federal Constitution}

Beginning with Lake v. Cameron, ${ }^{160}$ federal courts seemed quite receptive both to the least restrictive alternative doctrine and the compelled provision of community-based alternatives. Although Judge Bazelon expressed no opinion on whether the District of Columbia would be required to fund the creation of an "alternative, ${ }^{161}$ he nevertheless tacitly acknowledged that such an argument could be made on due process or equal protection grounds. ${ }^{162}$ Similar "close calls" occurred in several other lower federal court decisions; many articulating a statutory right to treatment in the least restrictive environment, but leaving open the issue of whether states could be forced to create such alternatives on constitutional grounds. ${ }^{163}$ By 1983 , no cases had yet determined whether a mentally ill person "at risk" of being civilly committed could sue on constitutional grounds to obtain adequate care in the least restrictive environment.

${ }^{160} 364$ F.2d 657 (D.C. Cir. 1966). For a discussion of the Lake case, see supra text accompanying notes 74-78.

161 Lake, 364 F.2d at 662.

${ }^{162}$ See id. at 662 n.19 (noting that " [s]uch questions might be whether so complete a deprivation of appellant's liberty basically because of her poverty could be reconciled with due process of law and the equal protection of the laws").

${ }^{16 s}$ See, e.g., Wyatt v. King, 773 F. Supp. 1508, 1510, 1516-17 (M.D. Ala.) (holding that the state must conduct periodic judicial reviews of the need for continued commitment, and in conducting those reviews, must consider the least restrictive alternatives "necessary and available"), order clarified by 781 F. Supp. 750 (M.D. Ala. 1991); Wyatt v. Stickney, 344 F. Supp. 373, 379, 384 (M.D. Ala. 1972) (noting that "[p]atients have a right to treatment in the least restrictive conditions necessary to achieve the purposes of commitment," and ordering the state to formulate and oversee the implementation of a patient plan), affd in part and remanded in part sub nom. Wyatt v. Aderholt, 503 F.2d 1305 (5th Cir. 1974); Lessard v. Schmidt, 349 F. Supp. 1078, 1095-96 (E.D. Wis. 1972) (noting that the mentally ill cannot be institutionalized if other less restrictive, equally effective, alternatives are available, but leaving open the issue of whether states were required to provide alternative programs), vacated and remanded on other grounds, 414 U.S. 473 (1974); see also Dixon v. Weinberger, 405 F. Supp. 974, 979-80 (D.D.C. 1975) (requiring both the federal government and the District of Columbia to submit plans detailing their intentions on how best to provide the mentally ill plaintiffs in this case with a less restrictive placement than St. Elizabeth's Hospital where it was deemed they were inappropriately held). Dixon goes the farthest of all the cases in establishing a positive right to least restrictive alternatives. See id. However, Dixon was decided on statutory grounds and only concerned those whom the state had already institutionalized. See id. 


\section{The Youngberg Case}

Youngberg $v$. Romeo ${ }^{164}$ involved the claims of Nicholas Romeo, a profoundly retarded adult, involuntarily committed at the Pennhurst mental institution. Mr. Romeo presented three claims regarding the nature of his commitment: (1) that he be guaranteed safe conditions of confinement; (2) freedom from bodily restraints; and (3) minimal training and development of basic skills. He based all three claims on the Due Process Clause of the Fourteenth Amendment. ${ }^{165}$ Although the Court accepted all three claims, ${ }^{166}$ it chose to read the third right, that of minimal training, as restricted to "such training as an appropriate professional would consider reasonable to ensure his safety and to facilitate his ability to function free from bodily restraints." 167

In further determining whether the state had violated $\mathrm{Mr}$. Romeo's rights, the Court reasoned that it would defer to the judgment of mental health professionals unless it could be shown that the professionals' decisions were clearly unfounded. ${ }^{168}$ By entitling the professionals' conclusions to a presumption of correctness, ${ }^{169}$ and thereby subjecting due process claims of the mentally ill to minimal level scrutiny, the Court left little doubt that a right to community-based treatment, ${ }^{170}$ that is, treatment in the least restrictive setting, would not be found in the U.S. Constitution. Although the Court had not explicitly addressed the least restrictive

164457 U.S. 307 (1982).

165 See id. at 315-17.

${ }^{165}$ See id. at 318, 322.

${ }^{167}$ Id. at 324 . The Court noted that "[a]s a general matter, a State is under no constitutional duty to provide substantive services for those within its border." Id. at 317. Nonetheless, the Court conceded that the state has a duty to provide services and care to those whose liberty it had restricted. See id. at 322.

${ }^{168}$ See id. at 323.

169 The degree to which the Court was willing to defer to the judgment of mental health professionals is fascinating. As the Court noted, "liability may be imposed [on the professional] only when the decision by the professional is such a substantial departure from accepted professional judgment, practice, or standards as to demonstrate that the person responsible actually did not base the decision on such a judgment." Id. The Court failed to indicate what constitutes accepted professional judgments, practices, and standards. Presumably, mental health professionals define them. Such a deferential standard is reminiscent of the pre-1960 "medical model" of civil commitment when mental health professionals were given virtual carte blanche authority to devise their own treatment programs. See LA FOND \& DURHAM, supra note 11 , at $83-85$.

${ }^{170}$ Note that the Court has acknowledged that an individual cannot be involuntarily confined for mental illness if the state provides no treatment. See O'Connor v. Donaldson, 422 U.S. 563, 574-76 (1975). 
alternative doctrine, the clear implications of the decision are that mental health professionals, not courts, will determine which types of treatment and treatment settings are most appropriate. Since professional judgment, as already discussed, ${ }^{171}$ is unlikely to be very liberal, relying on professional judgment in striking a balance between treatment needs and civil liberties is not really striking a balance, but rather ensuring an outcome, that outcome being civil commitment. ${ }^{172}$

Several court of appeals decisions interpreting Youngberg have made the implications of that landmark case more explicit. ${ }^{173}$ Although some decisions actually resulted in the plaintiffs' being placed in community settings, the courts never strayed from the Youngberg mandate, releasing individuals into the community only when there was a clear consensus among mental health professionals that the individuals belonged in the community. ${ }^{174}$ Moreover,

171 See supra note 103 and accompanying text.

172 Youngberg involved the rights of the developmentally disabled. As will be discussed, infra, the courts have tended to be less solicitous of the rights of those individuals with mental illness than with mental disabilities. But see Hellerv. Doe, 113 S. Ct. 2637, 2645 (1993) (accepting as rational Kentucky's requiring a higher burden of proof for the mentally ill than for the mentally disabled before the state can civilly commit; the Court emphasized, however, its deference to the state in light of Youngberg).

${ }^{173}$ See Jackson v. Fort Stanton Hosp. \& Training Sch., 964 F.2d 980, 991 (10th Cir. 1992) (interpreting Youngberg, the court held that "the mere fact that the [state] consider[ed] the availability or unavailability of community services when they ma[d]e care and training recommendations does not, alone, support a conclusion that the [state] fail[ed] to exercise reasonable judgment"); Lelsz v. Kavanagh, 807 F.2d 1243, 1247 (5th Cir.), cert. denied, 483 U.S. 1057 (1987); Clark v. Cohen, 794 F.2d 79, 93 n.9 (3d Cir.), cert. denied, 479 U.S. 962 (1986); Society for Good Will to Retarded Children v. Cuomo, 737 F.2d 1239, 1250-51 (2d Cir. 1984); Rennie v. Klein, 720 F.2d 266, 268-69 (3d Cir. 1983).

In Society for Good Will, the court reiterated the restricted interpretation of Youngberg, noting that "[e]ven if every expert testif[ied] ... that another type of treatment or residence setting might be better, the federal courts . . . may rule only on whether a decision to keep residents at [the institution] is a rational decision based on professional judgment." Society for Good Will, 737 F.2d at 1248-49. The court reversed the district court's finding that residents in the state mental institution were entitled to community placement. See id. The courts in Rennie, $720 \mathrm{~F} .2 \mathrm{~d}$ at 266, and Phillips v. Thompson, 715 F.2d 365 (7th Cir. 1983), reached similar conclusions. Several other lower federal court decisions declared explicitly that there existed no constitutional right to placement in the least restrictive community. See, e.g., Daniel B. v. O'Bannon, 633 F. Supp. 919, 924 (E.D. Pa. 1986).

${ }^{174}$ See Clark v. Cohen, 794 F.2d 79, 85-86 (3d Cir.) (noting that the professional staff where Ms. Clark was committed were all in agreement that her confinement had been unnecessary since 1976), cert. denied, 479 U.S. 962 (1986); Thomas S. v. Morrow, 781 F.2d 367, 374 (4th Cir. 1986) (noting that professional judgment had repeatedly recommended Thomas's placement in the community), cert. denied, 476 U.S. 1124 
most of those cases involved individuals currently in institutions and dealt with their right to be released and placed in community settings, or to have certain basic rights assured within the institution. ${ }^{175}$ None of those cases concerned the rights of individuals not yet institutionalized, and none came close to requiring the state to provide substantive assistance to the mentally ill through the creation of community mental health services.

Although the federal district and circuit courts have admittedly attempted to breathe life into the requirement of least restrictive care, without guidance and support from the Supreme Court, their attempts will never definitively shape the law. ${ }^{176}$

\section{The Pennhurst II Case}

As will be discussed shortly, most states do formally require that less restrictive alternatives be considered in determining whether commitment is the most appropriate treatment setting. ${ }^{177}$ After the Supreme Court's decision in Pennhurst State School and Hospital v. Halderman ${ }^{178}$ ( $"$ Pennhurst $I I$ "), however, federal court judges cannot force reluctant state officials to consider these alternatives. ${ }^{179}$ Interpreting the Eleventh Amendment as barring federal courts from ordering state officials to comply with state laws, the Supreme Court effectively left the rights of the mentally ill in the hands of the states.

(1986); Lelsz v. Kavanagh, 629 F. Supp. 1487, 1493 (N.D. Tex. 1986) (requiring lower courts to defer to the judgment of professionals), rev'd in part, aff'd in part, $807 \mathrm{~F} .2 \mathrm{~d}$ 1243 (5th Cir.), cert. denied, 483 U.S. 1057 (1987).

${ }^{175}$ See Armstead v. Coler, 914 F.2d 1464 (11th Cir. 1990) (affirming the lower court's finding that mentally disabled plaintiffs had been denied appropriate services while committed in an institution).

${ }^{176}$ While the Supreme Court assumed an aggressive posture during the 1970s, amenable to all sorts of institutional reform litigation, see Perlin, supra note 98, at 1256-57 n.36, the Court's posture during the 1980s changed radically. As Perlin notes, "the fact is inescapable that the Court has not-either covertly or overtlyencouraged expansive decisionmaking in institutional cases brought on behalf of the mentally disabled." Id. at 1261. A similarly pessimistic read of the court was voiced by Alan Meisel: "The most striking conclusion arising from the [major] mental health cases in which the Supreme Court has engaged in plenary review is that the Court cannot be relied upon to break new constitutional ground in securing rights to psychiatric patients on the civil side of the mental health system." Alan Meisel, The Rights of the Mentally Ill Under State Constitutions, 45 LAW \& CONTEMP. PROBS. 7, 15 (1982).

${ }_{177}$ See infra note 186 and accompanying text.

178465 U.S. 89 (1984).

179 Because litigants could "forum shop," many claims made their way to federal district court, challenging the manner in which state law had been enforced. 


\section{State Statutes}

As discussed earlier, states have in recent years passed laws making it easier to civilly commit the homeless mentally ill. ${ }^{180}$ What was a trend in the mid-1980s has now become the norm. Today, virtually all states provide for the civil commitment of those whose condition is either deteriorating or can be labelled "gravely disabled." 181 As compared to 1974, when only four states had gravely disabled laws or functional equivalents, ${ }^{182}$ today there are 39 states that employ this criteria. ${ }^{183}$ Several other jurisdictions

${ }^{180}$ See supra text accompanying notes 56-60.

181 Gravely disabled is generally defined as being unable to provide for one's essential needs. See, e.g., ILL. ANN. STAT. ch. 405, para. 5/1-119 (Smith-Hurd 1993) (providing that a "person who is mentally ill and who because of his illness is unable to provide for his basic physical needs so as to guard himself from serious harm" is subject to involuntary submission).

The "deterioration" standard is generally used to extend the state's reach to the deinstitutionalized homeless who, without community support, do not receive the support necessary for their health and safety. See, e.g., OR. REv. STAT. ANN. $\$ 426.005$ (2) (1987 \& Supp. 1992); see also supra note 56. Despite the obvious extension of the states' parens patriae powers, the "deterioration" standard has survived several constitutional challenges. See, e.g., State v. Brungard, 789 P.2d 683, 687 (Or. Ct. App. 1990); In re LaBelle, 728 P.2d 138, 146 (Wash. 1986).

182 See Kaufman, supra note 57 , at 353 n.94.

${ }^{183}$ In addition to the 10 states which provide for "deterioration" commitments, see supra note 56 , the following 39 states allow for the commitment of those deemed "gravely disabled" or equivalently "unable to provide for basic needs." See ARIz. REV. STAT. ANN. § 36-501(15) (Supp. 1992) ("gravely disabled"); ARK. CODE ANN. § 20-47$207(c)(1)(C)$ (Michie 1991) (noting that "a clear and present danger to himself is established by demonstrating that the person's behavior demonstrates that he so lacks the capacity to care for his own welfare"); CAL. WELF. \& INST. CODE $\$ 5008(h)$ (West 1984 \& Supp. 1993) ("gravely disabled"); Colo. REv. STAT. \$ 27-10-102(5)(a) (1989) ("gravely disabled"); CoNN. GEN. STAT. ANN. \$ 17a-495 (West 1992) ("gravely disabled"); FLA. STAT. ANN. $\$ 394.467(1)(a)$ (West 1993) (noting that a "person may be involuntarily placed for treatment upon a finding of the Court . . . that . . . he is manifestly incapable of surviving alone .. . and . . . he is likely to suffer from neglect or refuse to care for himself"); GA. CODE ANN. § 37-3-1(9.1)(A)(ii) (Supp. 1993) (characterizing an "[i]npatient [as] a person who is mentally ill and . . . who is ... unable to care for that person's own physical health and safety"); HAw. REv. STAT. \$ 334-1 (1985) ("gravely disabled"); IDAHO CODE \$66-317(n) (1989) ("gravely disabled"); ILI. ANN. STAT. ch. 405, para. 5/1-119(2) (Smith-Hurd 1993) (defining a "'[p]erson subject to involuntary admission' . . . [as] . . . [a] person who . . . because of his illness is unable to provide for his basic physical needs"); IND. CODE ANN. § 1226-1-1 (West Supp. 1992) ("gravely disabled"); IOWA CODE ANN. \$ 229.1(14)(c) (West 1993) (characterizing as "[s] eriously mentally impaired' . . . the condition of a person who ... because of that illness [i]s unable to satisfy the person's needs for nourishment, clothing, essential medical care, or shelter"); KY. REV. STAT. ANN. \$ 202A.011(2) (Michie/Bobbs-Merrill 1991) (describing the conduct of one who is a "[d]anger . . . to self . . . [as] including actions which deprive self, family or others of the basic means of survival including provision for reasonable shelter, food, or 
clothing"); LA. REv. STAT. ANN. § 28:2(10) (West 1989) ("gravely disabled"); MASs. ANN. LAwS ch. 123, $\$ 1$ (Law Co-op. 1989) (defining the "[1]ikelihood of serious harm' [as] . . . a very substantial risk of physical impairment or injury to a person himself as manifested by evidence that ... he is unable to protect himself in the community"); MICH. COMP. LAWS ANN. $\$ 330.1401$ (b) (West 1992) (defining a “'person requiring treatment' [as] ... [a] person who ... . as a result of . . . mental illness is unable to attend to those of his basic physical needs such as food, clothing, or shelter"); MINN. STAT. ANN. § 253B.02 subd. 13(b) (West 1982 \& Supp. 1993) (defining "'[m]entally ill person' [as] any person [with mental illness] which . . . poses a substantial likelihood of physical harm to self . . . as demonstrated by . . . a failure to obtain necessary food, clothing, shelter, or medical care"); MISs. CODE ANN. § 4121-61(e) (1993) (defining “'[m]entally ill person' [as] any person who . . . poses a substantial likelihood of physical harm to himself. . . as demonstrated by . . . a failure to provide necessary food, clothing, shelter, or medical care"); MO. REV. STAT. $\S 632.005(9)(\mathrm{b})$ (1988 \& Supp. 1993) (characterizing the " physical harm' [as] . . . [an] inability to provide for his own basic necessities of food, shelter, safety or medical care"); MONT. CODE ANN. § 53-21-102(15) (1991) (defining the "[s]eriously mentally ill' [as] suffering from a mental disorder which has ... deprived the person afflicted of the ability to protect his life or health"); NEB. REV. STAT. \$ 83-1009(2) (1987) (characterizing a "'[m] entally ill dangerous person' . . [as] present[ing] . . . [a] substantial risk of serious harm to himself . . . as manifested by evidence of . . . inability to provide for his . . basic human needs"); NEV. REV. STAT. ANN. § 433A.115(2) (Michie 1991) (noting that “[a] person presents a clear and present danger of harm to himself if . . . he has [a]cted in a manner from which it may reasonably be inferred that ... he will be unable to satisfy his need for nourishment, personal or medical care, shelter, self-protection or safety"); N.H. REV. STAT. ANN. § 135-C:2(XV) (1990) (describing the "[s]everely mentally disabled' [as] having a mental illness which ... cause[s] a substantial impairment of a person's ability to care for himself or to function normally in society"); N.J. STAT. ANN. § 30:427.2(h) (West Supp. 1993) (defining "'[d]angerous to self' [as] mean[ing] that by reason of mental illness the person . . . is unable to satisfy his need for nourishment, essential medical care or shelter"); N.M. STAT. ANN. \& 43-1-3(K) (Michie 1993) ("grave passive neglect"); N.C. GEN. STAT. \$ 122C-3(11)(a) (1989 \& Supp. 1992) (describing an individual as a "[d]anger to himself [because] ... [t] the individual has acted in such a way as to show [t]hat he would be unable . . . to satisfy his need for nourishment, personal or medical care, shelter, or self-protection and safety"); OHIO REV. CODE ANN. \$ 5122.01(B)(3) (Anderson 1993) (defining a "' $[\mathrm{m}]$ entally ill person subject to hospitalization' . . . [as] a mentally ill person who . . . is not providing for his basic physical needs because of his mental illness"); OKLA. STAT. ANN. tit. 43A, \$ 1-103(14)(b) (West 1990 \& Supp. 1993) (defining a "'[p]erson requiring treatment" [as] ... a person ... who ... . is unable to attend to those of his basic physical needs such as food, clothing or shelter."); PA. STAT. ANN. tit. 50, § 7301(a) (Supp. 1993) (noting that " $[\mathrm{a}]$ person is severely mentally disabled when . . . his capacity to . . . care for his own personal needs is so lessened that he poses a clear and present danger of harm . . . to himself"); R.I. GEN. LAws § 40.1-5-2(14)(c) (1990) ("grave . . risk to his or her physical health and safety"); S.C. CoDE ANN. § 44-17-410(2) (Law. Co-op. 1985 \& Supp. 1992) (noting that "[a] person may be [committed if] ... that person is mentally ill and because of his condition is likely to cause harm to himself through neglect, inability to care for himself, personal injury or otherwise"); S.D. CoDIFIED LAWS ANN. § 27A-1-1(5)(b) (1992) (characterizing behavior as "'[d]anger to self" . . . which show[s] there is a danger of serious personal harm ... as evidenced by an inability to provide for some basic human needs such as food, clothing, shelter, 
have either interpreted their civil commitment laws more freely or have used outpatient and conditional commitments to serve their ends. ${ }^{184}$ Although these provisions do not by themselves exclude the possibility of treatment in the community, the fact that most of these provisions were devised as a reaction to the perceived growth of the mentally ill homeless population evinces a preference for getting the mentally ill out of the community, not back into it.

Of course, other state statutory provisions do provide procedural and substantive due process protections for the mentally ill. Ever since a federal district court in Alabama appended a model patient's bill of rights to one of its decisions, ${ }^{185}$ states have been very receptive to incorporating such rights into their own statutes. In fact, as of 1985, forty-four states had enacted statutes that to some extent embodied the right to treatment in the least restrictive setting. ${ }^{186}$

physical health or personal safety. "); TENN. CODE ANN. § 33-6-104(a)(1)(D) (1984 \& Supp. 1993) (noting that a person can be committed if and only if "the person is unable to avoid severe impairment or injury from specific risks"); UTAH CODE ANN. § 62A-12-234(10)(b) (1989 \& Supp. 1993) (noting that the court will commit if the court finds that the patient "poses an immediate danger of physical injury to himself which may include the inability to provide the basic necessities of life"); VT. STAT. ANN. tit. 18, § 7101(17)(B)(ii) (1987) (defining a "person in need of treatment' [as one] who is ... unable ... to satisfy his need for nourishment, personal or medical care, shelter, or self-protection and safety"); VA. CODE ANN. § 37.1-67.3 (1990 \& Supp. 1993) (noting that a person can be committed if he is "so severely mentally ill as to be substantially unable to care for himself"); W. VA. CODE § 27-1-12(1) (1992) (characterizing a person as "[1]ikely to cause serious harm' [if he has] a substantial tendency to physically harm himself which is manifested by ... conduct, either active or passive, which demonstrates that he is dangerous to himself"); WIs. STAT. ANN. $\S 51.15(1)(a)(4)$ (West 1987) (an individual may be taken into custody if she is "unable to satisfy basic needs for nourishment, medical care, shelter or safety"); WYO. STAT. § 25-10-101(a)(ii)(C) (1990 \& Supp. 1993) (defining an individual who is "[d]angerous to himself or others' [as one who is] unable to satisfy basic needs for nourishment, essential medical care, shelter or safety").

${ }^{184}$ See supra notes 57-59 and accompanying text.

${ }^{1 e 5}$ See Wyatt v. Stickney, 344 F. Supp. 373, 379-86 (M.D. Ala. 1972); Perlin, supra note 98, at $1299 \&$ n.357 (discussing the effect Wyatt had on the states).

${ }^{186}$ See Keilitz et al., supra note 9, at 709. Keilitz summarizes the material as follows: "39 states now require courts to consider alternatives to hospitalization prior to or at the time of the actual involuntary commitment." Id. at 709 n.101. Five other states allow courts the discretion to consider least restrictive alternatives, but do not require it. See id.; see also BRAKEL ET AL., supra note 30, at 114-19, tbl. 2.6, cols. 7-8 (detailing prehearing procedures for the mentally ill for all 50 states); id. at 122-26, tbl. 2.7, col. 16 (detailing hearing and post-hearing procedures for the mentally ill for all 50 states). Brakel notes that " 26 states require that patients receive, while institutionalized, the least restrictive form of treatment" as well. $I d$. at 266. The data are for statutory provisions in existence in 1985. 
As applied, however, some state courts, in interpreting their civil commitment criteria, have viewed the least restrictive alternative condition to civil commitment as a "mere formality." ${ }^{187}$ Granted, most courts have remained faithful to the doctrine and its particular statutory requirements. ${ }^{188}$ But few courts have construed state

${ }^{187}$ See, e.g., In re Robinson, 601 N.E.2d 712, 717 (III. 1992) (characterizing as "harmless error," Illinois's failure to present a formal predispositional report on less restrictive treatment availability as required by law); see also Schwartz \& Costanzo, supra note 58, at 1347 n.78 (noting that in North Carolina, despite the existence of outpatient commitment procedures in lieu of inpatient institutionalization, little use was made of the procedure).

In 1977, Hoffman and Foust surveyed Virginia state judges on what treatment options they would choose and found that judges were reluctant to investigate community options. See Hoffman \& Foust, supra note 66, at 1122-37. For example, when asked:

While hospitalization would "probably be beneficial," the examining physician testifies that it would "definitely not be necessary" if the proposed patient could be admitted to an intermediate care facility. No intermediate care facility is available. You would:

(1) Commit to institution

(2) Dismiss the petition

When the grounds for commitment for the hypothetical patient was "unable to care for self," $69 \%$ said they would commit to an institution; $31 \%$ would have dismissed the petition.

Id. at 1128 , tbl. II.

${ }^{188}$ According to Perlin, "[a] review of several pertinent cases reveals that most [state] courts have continued to read relevant state statutes broadly even in the aftermath of Youngberg." Perlin, supra note 98, at 1312. For example, in Chasse v. Banas, 399 A.2d 608 (N.H. 1979), the New Hampshire Supreme Court, in arguing that the state hospital had a duty to provide adequate and humane treatment, held that the legislature's enunciation of general goals also implied the existence of civil rights for the mentally ill. See id. at 610; see also Estate of Early v. Early, 673 P.2d 209, 211 (Cal. 1983) (holding that "the trial court's failure to admit evidence of and to instruct on the availability of assistance of others to meet the basic needs of a person afflicted with a mental disorder was prejudicially erroneous requiring reversal"); Foy v. Greenblott, $190 \mathrm{Cal}$. Rptr. 84, 90 (Ct. App. 1983) (holding that the requirement to treat patients under the least restrictive conditions feasible implies that the institution should minimize interference with a patient's autonomy); In re James, $507 \mathrm{~A} .2 \mathrm{~d} 155$, 157 (D.C. 1986) (requiring, on statutory grounds, the city to make explicit findings that inpatient treatment is the least restrictive alternative available before revoking a patient's outpatient commitment); In re Long, 606 N.E.2d 1259, 1264 (Ill. App. Ct. 1992) (noting that the fact that the plaintiff did not want to be put into a halfway house or other less restrictive placement setting was irrelevant because the Florida statute did not require plaintiff agreement); In re James, 547 N.E.2d 759, 761-62 (Ill. App. Ct. 1989) (finding that it was "contrary to the balancing of interests" established by the state code to not require consideration of a predispositional report on the availability of alternative treatment settings); Rogers v. Commissioner of Dep't of Mental Health, 458 N.E.2d 308, 321 (Mass. 1983) (holding that the civilly committed have a right to refuse treatment under state law, and that any involuntary injection of drugs can only occur if no less intrusive alternatives exist); In re Danielson, 398 
statutory provisions to require the development of community-based services, ${ }^{189}$ despite virtually universal recognition that community mental health services are less restrictive and more effective than civil commitment. ${ }^{190}$ In fact, a majority of the states' civil commitment schemes explicitly require only the consideration of less restrictive alternatives that are "available."191 And since the community mental health centers that have been developed rarely cater to the needs of the chronically mentally ill, ${ }^{192}$ what is "avail$a b l e n$ is usually inappropriate. The statutory right to live in the least restrictive setting and to be treated in the least restrictive manner

N.W.2d 32, 36-37 (Minn. Ct. App. 1986) (remanding to the trial court to consider less restrictive alternatives as required by state law); New Jersey Ass'n for Retarded Citizens v. New Jersey Dep't of Human Servs., 445 A.2d 704, 712 (N.J. 1982) (holding that the state statute requires the use of the least restrictive alternative and that this requirement implies the provision of the "spectrum" of settings); In re J.A.D., 492 N.W.2d 82, 86-87 (N.D. 1992) (holding that the pro forma consideration of less restrictive alternatives was not sufficient); O'Callaghan v. L.B., 447 N.W.2d 326, 328 (N.D. 1989) (holding as reversible error the state's failure to consider halfway homes which were available); Kottke v. U.A.M., 446 N.W.2d 23, 28 n.4 (N.D. 1989) (urging active consideration of less restrictive alternatives); Rhode Island Dep't of Mental Health, Retardation \& Hosps. v. R.B., 549 A.2d 1028, 1030 (R.I. 1988) (holding that the state statute required the court to fully consider alternatives to inpatient care); In re R.A., 501 A.2d 743, 744 (Vt. 1985) (broadly interpreting its civil commitment statute); In $r e$ W.H., 481 A.2d 22, 25 (Vt. 1984) (holding that although a consideration of less restrictive alternatives is only legislatively required for a commitment hearing, it is also required before involuntarily transporting an individual to a hospital for a psychiatric examination).

${ }^{189}$ See supra note 80.

${ }^{190}$ See supra notes $116-36$ and accompanying text.

${ }^{191}$ See ALA. CODE $\$ 22-52-10.1$ (a) (Supp. 1993); ALASKA STAT. $\$ 47.30 .735$ (d) (1990); ARIz. REV. STAT. ANN. § 36-540(B) (1993); ARK. CODE ANN. § 20-47-202I(i) (Michie 1991 \& Supp. 1993); COLO. REV. STAT. § 27-10-101(1)(b) (1989); CONN. GEN. STAT. ANN. § 17a-498(c) (West 1992); DEL. CODE ANN. tit. 16, § 5010(2) (1983 \& Supp. 1992); FLA. STAT. ANN. § 394.467(1)(b) (West 1993); HAW. REV. STAT. § 334 60.2(3) (1985 \& Supp. 1992); IDAFO CODE § 66-329(k)(2) (1989 \& Supp. 1993); ILL. ANN. STAT. ch. 405, para. 5/3-810 (Smith-Hurd 1993); Ky. REv. STAT. ANN. \$ 202A.011(7) (Michie/Bobbs-Merrill 1991); ME. REV. STAT. ANN. tit. 34-B, $\S 3801(4)(C)$ (West 1988); MD. CODE ANN., HEALTH-GEN. § 10-617(a)(5) (1990); MICH. COMP. LAWS ANN. § 330.1469(1) (West 1992); MONT. CODE ANN. § 53-21-127(2)(c) (1991); NEB. REV. STAT. § 83-1035 (1987); N.J. STAT. ANN. § 30:4-27.2(m) (West Supp. 1993); N.C. GEN. STAT. § 122C-2 (1989); N.D. CENT. CODE § 25-03.1-21(1) (1989 \& Supp. 1993); OHIO REV. CODE ANN. § 5122.15(E) (Anderson 1993); ORIA. STAT. ANN. tit. 45A, § 5-405(A) (West 1990 \& Supp. 1993); PA. STAT. ANN. tit. 50, § 7304(f) (Supp. 1993); R.I. GEN. LAWS § 40.1-5-8(10) (1990); S.D. CoDIFIEd LAWS ANN. § 27A10-9.1(3) (1992); TeNN. CODE ANN. § 33-3-601(b)(1) (1984 \& Supp. 1993); TEX. HEALTH \& SAFETY CODE ANN. \$§ 571.004(1), 576.021(1) (West 1992); VT. STAT. ANN. tit. 18, § 7617(c) (1987); W. VA. CODE § 27-5-3(a) (1992).

${ }^{192}$ See supra notes $43-45$ and accompanying text. 
appropriate to one's needs is a right guaranteed in theory, but rarely realized in fact.

At a time when federal courts and state and federal legislatures are steadily eviscerating individual rights, advocates for the mentally ill must look elsewhere. The place to start is with state constitutions. ${ }^{193}$

\section{State Constitutionalism}

"Four years ago, Professor Alan Meisel characterized state constitutions as a 'virtually untapped source of rights' and perhaps 'the most promising source of rights' for the mentally disabled."194 Writing in 1987, Michael Perlin presented evidence that since Meisel's 1983 article there had been a "modest body of [state constitutional] law" developed recognizing rights for the mentally disabled. ${ }^{195}$ Written six years after Perlin, this Comment con-

193 While state constitutions will not necessarily be interpreted more liberally than state statutes, as the remainder of this Comment will show, claims that are expressed in "constitutional rights" terms deserve, and often get, more attention. Moreover, it is not that state statutes do not evince a concern for treatment in the least restrictive setting; for, as shown, they in fact do. Rather, the problem is that courts are often reluctant to foist economic mandates upon the legislature when the courts engage in statutory construction. But such hesitancy, though still present, should not be as chilling when the courts engage in constitutional interpretation.

${ }_{194}$ Perlin, supra note 98, at 1279 (quoting Meisel, supra note 176, at 9, where Meisel noted that " $t]$ o date, only a few significant cases involving the rights of persons on the civil side of the mental health process have been decided on the basis of state constitutional provisions").

The enthusiasm for the use of state constitutions has not come from academia alone. Judges, both federal and state, have evinced a strong desire to make better use of state constitutions. For example in 1983, New Jersey Supreme Court Associate Justice Pollock, warned that "[a] lawyer who ignores the change in tide towards state constitutions runs the same risk as a sailor who ignores a change in the tides of the sea." Stewart G. Pollock, State Constitutions as Separate Sources of Fundamental Rights, 35 RUTGERS L. REV. 707, 715 (1983).

${ }^{195}$ See Perlin, supra note 98, at 1280. Nowhere in Perlin's analysis, however, was there mention of a constitutional right to treatment in the least restrictive setting. Perlin divided his analysis into four parts. First, he explored procedural rights in the civil commitment process, citing several cases that established a right to periodic reviews of the propriety of commitment, the right to be present at the commitment hearings, and the right to a jury trial. See id. at 1280-83. Second, Perlin discussed cases interpreting state constitutions as providing a right to refuse treatment, focusing primary attention on the New York case, Rivers v. Katz, 495 N.E.2d 337 (N.Y. 1986). See id. at 1283-92. Third, he noted the dearth of cases interpreting a state constitutional right to treatment. See id. at 1292-93. Finally, he concluded with a short discussion on rights involving sterilization. See id. at 1293-94. While the language of many of the cases analyzed by Perlin point to the possibility of a right to community-based treatment, neither Perlin nor any other scholar has comprehensively 
cludes that state constitutions can provide not simply a "modest," but rather a potent source of rights protection for the mentally ill.

\section{A. History of the Role of State Constitutions}

The history of state constitutionalism reflects the historical relationship between the federal and state systems. Before the ratification of the U.S. Constitution, the original colonies had created detailed bills of rights. ${ }^{196}$ In fact, according to California Supreme Court Justice Stanley Mosk, "[w]hen the Founding Fathers put this one nation together, they recognized the primacy of the states in protecting individual rights. ${ }^{197}$ The independence and primacy of state constitutionalism was further solidified in 1833 when Chief Justice John Marshall decided Barron v. Baltimore, ${ }^{198}$ holding that the guarantees of the Bill of Rights were not directly binding on the states. ${ }^{199}$

This federal-state dichotomy, however, began to change after passage of the Fourteenth Amendment. Although the process commonly termed incorporation ${ }^{200}$ did not start for another sixty years, ${ }^{201}$ the groundwork was laid for increased federal involve-

addressed the issue.

${ }^{196}$ See Developments in the Law: The Interpretation of State Constitutional Rights, 95 HARV. L. REV. 1324, 1326 (1982) [hereinafter Developments].

${ }_{197}$ Stanley Mosk, State Constitutionalism: Both Liberal and Conservative, 63 TEX. L. REV. 1081, 1082 (1985). Soon a tradition of state court innovation began, including the formation of the concept of judicial review-long before Chief Justice Marshall had created the doctrine in Marbury v. Madison, 5 U.S. (1 Cranch.) 137 (1803). See A.E. Dick Howard, State Courts and Constitutional Rights in the Day of the Burger Court, 62 VA. L. Rev. 873, 877 (1976) (discussing the case of Commonwealth v. Caton, 8 Va. (4 Call) 5, 8 (1782), where Judge George Wythe declared an act of the state legislature unconstitutional). Howard also notes that "[1]ong before the adoption of the Fourteenth Amendment, state courts had begun to develop a body of substantive due process law, drawing on state constitutional due process or 'law of the land' provisions." Id. at 881-82.

19832 U.S. (7 Pet.) 243 (1833).

${ }^{199}$ See id. at 250 (reasoning that "[h]ad the framers . . . intended them to be limitations on the powers of the state governments, they would have . . . [explicitly] expressed that intention"). Perlin notes that the case reflected the belief that state constitutional protections were enough, and that passage of the first eight amendments had been sought more to allay the fears of those opposed to the Constitution than to create a justiciable source of rights. See Perlin, supra note 98, at 1269.

${ }^{200}$ Incorporation refers to the application of the Bill of Rights to the states through the Due Process Clause of the Fourteenth Amendment. See LAURENCE H. TRIBE, AMERICAN CONSTITUTIONAL LAW 772-74 (2d ed. 1988).

${ }^{201}$ Gitlow v. New York, 268 U.S. 652 (1925), marked the beginning of the incorporation movement. In Gitlow, the Supreme Court declared that the First Amendment guarantee of freedom of speech applied to state actions as well. See id. 
ment in the affairs of the states. By the time of Chief Justice Earl Warren's tenure on the Court in the late 1960s, most of the Bill of Rights had been applied to the states. ${ }^{202}$ This, of course, meant that state constitutionalism had taken a back seat. More importantly, however, incorporation "obscured the functional independence of the original state ... guarantees." ${ }^{203}$ In time, state courts would look "no further than federal constitutional law." "204

By the end of the 1970s, however, it became apparent that state constitutions would once again play a more prominent role. The primary catalyst for the re-emergence of state constitutionalism was the rights-retrenchment jurisprudence of the Burger Court. ${ }^{205}$ Beginning with Chief Justice Burger and continuing today under the leadership of Chief Justice Rehnquist, the unmistakable trend has been for the Court to narrowly and restrictively interpret the guarantees of liberty advanced during the Warren years. In reaction, state courts have increasingly looked to state constitutional provisions to fill the void. ${ }^{206}$

at 666.

${ }^{202}$ See TRIBE, supra note 200, at 772-73. Justice William Brennan noted this by writing:

Most fittingly, the date upon which Benton, the capstone of the revolution, was handed down was also the final day of Earl Warren's service on the Court. The tenure of this great Chief Justice saw the conversion of the Fourteenth Amendment into a guarantee of individual liberties equal to or more important than the original Bill of Rights.

William J. Brennan, Jr., The Bill of Rights and the States: The Revival of State Constitutions as Guardians of Individual Rights, 61 N.Y.U. L. REv. 535, 545 (1986) (referring to Benton v. Maryland, 395 U.S. 704 (1969), where the Court held that the Double Jeopardy Clause of the Fifth Amendment applies to the states).

${ }^{203}$ Perlin, supra note 98, at 1270 (quoting Developments, supra note 196, at 1328).

${ }^{204}$ Id. (quoting Howard, supra note 197, at 878).

${ }^{205}$ Not all commentators attributed the rebirth of state constitutionalism to the rights retrenchment of the Burger years. James Henretta notes that after Baker v. Carr, 369 U.S. 186 (1962), state legislatures, forced into equal apportionment, became more democratic, and thus more responsive to populist-based state constitutional revisions. See James A. Henretta, Foreword: Rethinking the State Constitutional Tradition, 22 RUTGERS L.J. 819, 839 (1991). These revisions placed greater checks on the state legislatures. See id. at 839. Moreover, many state courts, their dockets cleared by the rush to liberal federal venues, became available to address state constitutional issues in a more coherent, independent fashion. Instead of being a reaction to the Burger Court, the revival of state constitutionalism, seems be the logical offshoot of the advances made during the Warren years. In any case, no one disputes the increased importance of state constitutions during this time.

${ }^{206}$ See G. Alan Tarr, Constitutional Theory and State Constitutional Interpretation, 22 RUTGERS L.J. 841, 841 (1991) (arguing that reliance on state constitutions was in reaction to the Burger Court's decisions); see also Brennan, supra note 202, at 548 (noting that "[b]etween 1970 and 1984, state courts, increasingly reluctant to follow 


\section{B. A More Aggressive Jurisprudence}

In Alderwood Associates v. Washington Environmental Council, ${ }^{207}$ the Washington Supreme Court cited two reasons why state supreme courts can afford to be more aggressive protectors of individual rights than the U.S. Supreme Court.

[F]irst ... when the United States Supreme Court interprets the Fourteenth Amendment, it establishes a rule for the entire country.... a rule which accounts for all the variations from state to state and region to region....

The second factor, which is related to the first and actually results from it, is that the Supreme Court must take a conservative theoretical approach to applying the Fourteenth Amendment. ${ }^{208}$

the federal lead, have handed down over 250 published opinions holding that the constitutional minimums set by the United States Supreme Court were insufficient to satisfy the more stringent requirements of state constitutional law"); William J. Brennan, Jr., State Constitutions and the Protection of Individual Rights, 90 HARV. L. REV. 489,495 (1977) (noting that "more and more state courts are construing state constitutional counterparts of provisions of the Bill of Rights as guaranteeing citizens of their states even more protection than the federal provisions, even those identically phrased"); Ronald K.L. Collins et al., State High Courts, State Constitutions and Individual Rights Litigation Since 1980: A Judicial Survey, PUBLIUS, Summer 1986, at 141,142 (noting, after surveying state high court judges, that there has been an increase in the use of state constitutions since 1977). Collins also points out variations regionally, noting that the Northeast and the West tend to be more prone to using independent state constitutional analyses than their Midwestern and Southern counterparts. See id. at 146-50; see also Michigan v. Mosley, 423 U.S. 96, 120-21 (1975) (reminding the states that they could properly bestow on their citizens more individual rights than the federal constitution requires) (Brennan, J., dissenting).

A frequently cited example of state courts' acceptance of Brennan's challenge in Mosley is the California Supreme Court's decision in People v. Disbrow, 545 P.2d 272 (Cal. 1976). See id. at $\mathbf{2 8 0}$ (reaffirming the "independent nature of the California Constitution and [the court's] responsibility to separately define and protect the rights of California citizens despite conflicting decisions of the United States Supreme Court interpreting the federal Constitution"); see also Ravin v. State, 537 P.2d 494, 511 (Alaska 1975) (holding that "possession of marijuana by adults at home for personal use is constitutionally protected under the Alaska constitution"); People v. Brisendine, 531 P.2d 1099, 1113 (Cal. 1975) (determining that "California citizens are entitled to greater protection under the California Constitution against unreasonable searches and seizures than that required by the United States Constitution"); State v. Sklar, 317 A.2d 160, 165 (Me. 1974) (holding that notwithstanding the U.S. Supreme Court's differing interpretation of the Sixth Amendment of the federal Constitution; the right to trial by jury is guaranteed "in all criminal prosecutions" under the Maine Constitution); People v. Jackson, 217 N.W.2d 22, 27 (Mich. 1974) (holding that "independent of any federal constitutional mandate . . . a suspect is entitled to be represented by counsel at a corporeal identification or a photographic identification").

${ }^{207} 635$ P.2d 108 (Wash. 1981).

${ }^{208} I d$. at 115 . 
Reserving judgment for only the most invasive, most generally illegitimate, governmental incursions into individual rights, the Supreme Court has evinced a concern for preserving its political capital. At the state level, however, "states may be political science laboratories, to experiment, to improvise, to test new theories. If a state experiment succeeds, others may follow. If it fails, only one of 50 states is affected. ${ }^{n 209}$

Moreover, separation of powers concerns that often constrain the Supreme Court's review of congressional legislation do not exist at the state level. Although state courts are not allowed to ride roughshod over the powers of state legislatures, they are generally expected to be more of a counterweight to the legislative branch than the Supreme Court is to Congress. ${ }^{210}$

${ }^{209}$ Stanley Mosk, The Power of State Constitutions in Protecting Individual Rights, 8 N. ILL. U. L. REV. 651, 652 (1988) (paraphrasing Justice Brandeis in New State Ice Co. v. Liebmann, 285 U.S. 262, 311 (1932) (Brandeis, J., dissenting)).

One of the best examples of how federalism concerns play out in constitutional jurisprudence is in the area of school-finance reform litigation. In deciding that disparities in educational expenditures across districts did not violate the Equal Protection Clause of the Fourteenth Amendment, the Supreme Court, in San Antonio Indep. Sch. Dist. v. Rodriguez, 411 U.S. 1 (1973), noted that

[q]uestions of federalism are always inherent in the process of determining whether a State's laws are to be accorded the traditional presumption of constitutionality. ... [I]t would be difficult to imagine a case having a greater potential impact on our federal system than the one now before us, in which we are urged to abrogate systems of financing public education presently in existence in virtually every State.

$I d$. at 44 . In response to the Supreme Court's concerns, several state courts explicitly referred to the lack of federalism questions in their determination that such disparities violated their own state constitutions. See, e.g., Serrano v. Priest, 557 P.2d 929, 952 (Cal. 1976) (noting that constraints of federalism are not applicable to determining whether a public school financing system violates the state's constitution), cert. denied, 432 U.S. 907 (1977); Robinson v. Cahill, 303 A.2d 273, 282 (N.J.) (noting that "there is absent the principle of federalism which cautions against too expansive a view of a federal constitutional limitation"), cert. denied, 414 U.S. 976 (1973), reh'g granted, 351 A.2d 713 (N.J.), cert. denied, 423 U.S. 913 (1975). For an analysis, see Peter J. Galie, The Other Supreme Courts: Judicial Activism Among State Supreme Courts, 33 SYRACUSE L. REv. 731, 790 (1982) (writing that "the absence of federalism concerns significantly alters the terms of the judicial activism debate ${ }^{n}$ ).

${ }^{210}$ State judges are often elected into office and state constitutions are frequently amended to reflect the popular concerns of the time. See Developments, supra note 196, at 1351-56 (discussing the political accountability of state judges and the susceptibility of state constitutions to revision in response to popular opinion); Brennan, supra note 202, at 551 (same). Thus, the state judiciary almost functions as another branch of the state legislature. For a discussion of the frequency by which state constitutions are amended, see Developments, supra note 196 , at $1354 \mathrm{n} .108$ (noting that between 1970 and 1979 states adopted a total of 946 amendments to their state constitutions). 


\section{Methodologies of State Constitutional Analysis}

The primary criticism levelled at state constitutional advocates is that their version of judicial activism runs the risk of becoming thoroughly unprincipled. ${ }^{211}$ Although political capital may not be as important to the state supreme courts as it is to the Supreme Court, ${ }^{212}$ any court that lacks the purse and the sword must rely on legitimacy for its primary source of authority. Therefore, " $[\mathrm{t}] \mathrm{he}$ challenge is to develop a jurisprudence of state constitutional law,

Federalism and separation of powers concerns are justifications strategically used by the Supreme Court for exerting judicial restraint on a given issue. As one commentator has noted, however, since adjudication at the state level is often as much a matter of strategy as it is legal interpretation, state courts may legitimately broaden and expand traditional conceptions of human rights. See Lawrence G. Sager, Foreword: State Courts and the Strategic Space Between the Norms and Rules of Constitutional Law, 63 TEX. L. REv. 959, 973-76 (1985) (discussing the strategic disparity between state courts and the U.S. Supreme Court).

Not all commentators are pleased with the growth of state court activism. Earl Maltz charges its advocates with being disingenuous. According to Maltz, the invocation of federalism as a justification for expansive state constitutionalism contradicts the long-held antagonism of the liberal wing of the Court to federalist principles. Maltz, an interpretivist, is troubled by instrumental, results-oriented jurisprudence, and sees the possibility of state court activism as infringing on other important rights. See Earl M. Maltz, The Dark Side of State Court Activism, 63 TEX. L. REV. 995, 1002, 1004 (1985) (arguing that state court activism restricts legislative choices); Earl M. Maltz, False Prophet-Justice Brennan and the Theory of State Constitutional Law, 15 HASTINGS CONST. L.Q. 429, 441-49 (1988) (advocating that state constitutional provisions be given precisely the same level of protection as analogous federal constitutional guarantees).

It is interesting to note, however, that not all interpretivists agree with Maltz. Even Chief Justice Rehnquist has acknowledged that state constitutions may provide greater protection. In Pruneyard Shopping Ctr. v. Robins, 447 U.S. 74 (1980), Rehnquist noted that Supreme Court decisions did "not limit the authority of the State ... to adopt in its own Constitution individual liberties more expansive than those conferred by the Federal Constitution." Id. at 81.

Rehnquist's acceptance of state activism reflects the conservatives' concern that states' rights be preserved. Although conservatives are, by definition, not usually receptive to judicial activism, many would find it difficult to challenge state court activism without being inconsistent. Indeed, many conservatives may be overjoyed by recent state activism in the area of substantive economic due process. Therefore, at least in theory, both conservatives and liberals are content with the growth in state judicial activism. See Gary L. McDowell, Foreword: Rediscovering Federalism? State Constitutional Law and the Restoration of State Sovereignty, 21 RUTGERS L.J. 797, 808, 818 (1990) (advocating that the Supreme Court give states greater leeway in areas such as abortion, religion, and gun control).

211 By unprincipled, I mean result-oriented, as opposed to reasoned and neutral.

212 See supra note 210. 
a jurisprudence that will make more predictable the recourse to and the results of state constitutional law analysis. ${ }^{n 213}$

Most common among state courts is a jurisprudence of original intent, or textualism. ${ }^{214}$ Traditionally employed in federal constitutional interpretations by those with more conservative leanings, textualism may not be, as a theoretical matter, the jurisprudence of choice for state constitutional advocates. Nevertheless, its use has, as a practical matter, legitimized more progressive rights-protection. $^{215}$ Moreover, textualism at the state level has not faced as much criticism as the federal version of original intent, further facilitating its application. ${ }^{216}$

Once a state court determines how to construe its own constitutional provisions, it must also consider, as an element of adjudication, its relationship to equivalent provisions in the federal constitution. The three most recognized methodologies for relating federal and state constitutional provisions are the primacy, supplemental/interstitial, and dual sovereignty models. ${ }^{217}$

${ }^{213}$ Pollock, supra note 194, at 708. Moreover, if state constitutionalism simply becomes a reaction to the Burger/Rehnquist era conservatism, then opposition will likely form and constitutional amendments reversing innovative state rulings will probably be enacted. A state constitutional jurisprudence, vis-a-vis federal constitutional analysis, will go a long way towards preserving the results of state court activism. While advocates for the mentally ill cannot decide for a court what methodological/jurisprudential approach it should take, arguments can, and should, assume a more principled form. See Tarr, supra note 206, at 846-47 (stating that there can be a principled basis for state rulings that diverge from U.S. Supreme Court rulings because state courts often have to interpret guarantees that have no analogue in the Constitution).

${ }^{214}$ See Tarr, supra note 206, at 848 (noting that the justifications for not following the lead of the Supreme Court pointed state judges toward textualism). Since state constitutions are by virtue of their detail very much like statutes, courts generally apply rules of statutory construction to state constitutional analysis. Depending on how liberal or conservative the court is, and how ambiguous the constitutional provisions that the court is interpreting are, statutory construction may allow for either broad or narrow interpretations of legislative intent. See William F. Swindler, State Constitutional Law: Some Representative Decisions, 9 WM. \& MARY L. REV. 166, 167-69 (1967) (stating that the basic rule of statutory interpretation allows for a degree of flexibility).

${ }^{215}$ See Tarr, supra note 206, at 853-55 (noting that advocates of state constitutionalism rely on textualism to legitimize independent state constitutional interpretations, because textual criteria are likely to command "universal assent").

${ }^{216} \mathrm{See} i d$. at 851-52. Since most state constitutions are frequently amended and many have been totally revamped within the last 30 years, the criticisms levelled against use of original intent at the federal level, in terms of ascertaining the intent of men dead for 200 years, do not apply with as much force in the context of state constitutionalism. Of course, determining whose intent is relevant and whose should be given priority remains a sticking point for any form of textualism.

${ }^{217}$ For a general discussion on each of these three methodologies, see Phylis $\mathbf{S}$. 
The primacy model is the most radical, and as the name connotes, the most independent of the three approaches. Under the primacy model, state courts rely first on their own state constitutions before seeking a remedy in analogous federal provisions. ${ }^{218}$ In doing so, the state courts not only insulate themselves from Supreme Court review, ${ }^{219}$ but also from doctrinal switches in more uncertain areas of the law. ${ }^{220}$ Although the primacy model has not been as popular as the other two models, presumably because of the added work involved in developing independent decisional grounds, several state courts have nonetheless used it. ${ }^{221}$

Bamberger, Methodology for Raising State Constitutional Issues, in RECENT DEVELOPMENTS IN STATe Constitutional LAw 287, $301-06$ (1985); Perlin, supra note 98, at 1274-75; Pollock, supra note 194, at 718.

${ }^{218}$ Under the traditional "adequate and independent state grounds" test, the Supreme Court used to assume that state court decisions were based on state constitutional grounds, and thus did not review them. See, e.g., Herb v. Pitcairn, 324 U.S. 117, 128 (1945) (stating that "we will not review a judgment of a state court that rests on an adequate and independent ground in state law"). Today, however, the Court has switched presumptions, requiring state courts to formally note that their judgments have only used federal cases merely for guidance, and that these federal cases did not compel the result reached by the state court. See Michigan v. Long, 463 U.S. 1032, 1040-41 (1983); see also Bamberger, supra note 217, at 290-98 (noting the Court's recent practice of reviewing state court decisions unless they are clearly premised on state law); Stewart G. Pollock, Adequate and Independent State Grounds as a Means of Balancing the Relationship Between State and Federal Courts, 63 TEX. L. REV. 977, 982 (1985) (noting that a state court discussing federal law must make a "plain statement" that it used federal law for guidance only). For a criticism of the Court's more restrictive standard, see Developments, supra note 196, at $1336-42$ (noting that there is no bright line between a state and federal constitutional basis).

${ }^{219}$ See Developments, supra note 196, at 1336 (noting that "the autonomy principle immunizes state court decisions from review").

220 An example of doctrinal uncertainty is the Supreme Court's search and seizure jurisprudence. Justice Linde of the Oregon Supreme Court has noted: "If we construe the search and seizure clause of our state constitutions to follow the latest Supreme Court holding under the fourth amendment ..., what is the state's law when the Supreme Court changes direction in the next [search and seizure] case?" Pollock, supra note 194, at 712-13 (quoting Hans A. Linde, First Things First: Rediscovering the State's Bill of Rights, 9 U. BALT. L. REV. 379, 394 (1980)).

Another more recent area of doctrinal development has been in the free exercise of religion jurisprudence. Until the Supreme Court handed down its decision in Employment Div., Dep't of Human Resources v. Smith, 494 U.S. 872 (1990), state courts generally applied a strict scrutiny/compelling interest test to free exercise claims. After Smith's adoption of a minimal level scrutiny/incidental effects test, see id. at $888-89$, state courts that had interpreted their free exercise provisions independently of the federal analog could still choose to follow the old standard. States that had relied exclusively on Supreme Court analysis, however, were left with fewer options.

${ }_{221}$ See, e.g., State v. Kaluna, 520 P.2d 51, 58 (Haw. 1974) (stating the court's willingness to extend the protection of Hawaii's Bill of Rights beyond those of the U.S 
As for the other two methodologies, the interstitial approach is, ironically, the more progressive one. Since under the interstitial model the U.S. Constitution is the primary source of protection, the premise behind the interstitial model is inherently conservative. Nevertheless, states are allowed to diverge from federal interpretations and raise rights above the federal floor as long as objective criteria such as more expansive textual language in state constitutions or historical facts justify such a divergence. ${ }^{222}$ In using the final methodological approach, dual sovereignty, state courts find support for their positions in both state and federal constitutions. The advantage of such an approach is that it insulates both state and federal law from review. ${ }^{223}$ The disadvantage is that state constitutional doctrine never develops independently of federal constitutional doctrine. ${ }^{224}$

Given the tension between the increased willingness of the Supreme Court to review state court decisions and the need to rise above the floor of federal rights in the mental health area, advocates

Bill of Rights); People v. Beavers, 227 N.W.2d 511, 517 (Mich.) (noting that "[w]e can ... afford[] protections beyond those required by the United States Supreme Court"), cert. denied, 423 U.S. 878 (1975); State v. Ball, 471 A.2d 347, 351 (N.H. 1983) (stating that the court does not feel "bound to adopt the federal interpretations"); State v. Johnson, 346 A.2d 66, 67 (N.J. 1975) (stating that "each state has the power to impose higher standards on searches and seizures under state law than is required by the Federal Constitution").

222 See, e.g., Right to Choose v. Byrne, 450 A.2d 925, 933 (N.J. 1982) (utilizing an explicit privacy provision in the state constitution to require Medicaid to provide assistance to women seeking an abortion, despite a Supreme Court holding to the contrary in Harris v. McRae, 448 U.S. 297 (1980)). For a discussion favoring the interstitial approach, see Developments, supra note 196, at 1357-59 (discussing the failings of the primacy model).

${ }^{223}$ Under the Supremacy Clause, states constitutionally cannot amend a decision that relies on an interpretation of federal law. Likewise, the federal courts cannot review a state court decision that relies on adequate and independent state grounds. See supra note 218.

${ }_{224}$ Justice Robert F. Utter believes, however, that the dual sovereignty model can help federal constitutional law develop more progressively. Utter points to several instances where state court decisions influenced subsequent Supreme Court opinions, particularly in the areas of judicial review, due process, free speech, and eminent domain. See Robert F. Utter, Swimming in the Jaws of the Crocodile: State Court Comment on Federal Constitutional Issues When Disposing of Cases on State Constitutional Grounds, 63 TEx. L. REV. 1025, 1030-41 (1985).

Despite Justice Utter's assurances, the clear import of the dual sovereignty approach is that even the most progressive constitutional interpretations depend on Supreme Court validation before they can take effect at the national level. Although a court using the dual sovereignty model claims an independent state constitutional basis for its decisions, heavy reliance on federal interpretations will likely subject its decisions to Supreme Court review. 
for the mentally ill would benefit from couching their arguments to satisfy the requirements of either the primacy or the interstitial models. Although not all state courts will be receptive to these two approaches, it is only by developing an independent source of constitutional rights for the mentally ill, which these models ensure, that a right to treatment in the least restrictive setting will ever be realized.

\section{Tools for Establishing Broader Rights}

Commentators have developed several bases for interpreting state constitutional provisions more liberally than their federal counterparts. ${ }^{225}$ The approaches which will be most useful depend, of course, on the courts in which they are applied. Historically, however, most state courts have relied primarily on textual differences for breathing expanded rights-protections into their state constitutions. ${ }^{226}$

${ }_{225}$ See, for instance, the seminal article by A.E. Dick Howard, supra note 197, at 935-40. Professor Howard lists seven bases for more expansive interpretation: (1) textual language; (2) legislative history; (3) state history and tradition; (4) localized issues that implicated federalism issues when handled by the Supreme Court; (5) minimal separation of powers issues that mandated judicial restraint for the Supreme Court; (6) recent constitutional amendments reflecting fundamental values of the state; and (7) the tradition of state courts as experimenters. See id.

${ }_{226}$ See, e.g., Kroger Co. v. O'Hara Township, 392 A.2d 266, 274-75 (Pa. 1978) (applying heightened scrutiny to Pennsylvania's blue law provisions that discriminated against businesses open on Sundays, and relying on Article III, $\S 32$ of the Pennsylvania Constitution which explicitly forbids trade regulation classifications); People v. Anderson, 493 P.2d 880, 898 (Cal.) (holding capital punishment unconstitutional because Article I, $\S 6$ of the California Constitution stipulates that "no cruel or unusual" punishment will be tolerated; unlike the federal analog which reads "no cruel and unusual" (emphasis added)), cert. denied, 406 U.S. 958 (1972).

Even when the provisions are identical, state courts have been known to interpret the state constitutional provisions more liberally. See, e.g., State v. Kaluna, 520 P.2d $51,58 \mathrm{n} .6$ (Haw. 1974) (expressing the policy of giving independent interpretation to identically worded provisions where such divergence results in greater protection of individual rights); State v. Johnson, 346 A.2d 66, 68 n.2 (N.J. 1975) (interpreting the state's search and seizure provisions more liberally than the federal analog); State v. Opperman, 247 N.W.2d 673, 674-75 (S.D. 1976) (same).

State courts often combine constitutional provisions to justify more expansive interpretations. An expression of such an approach can be found in City of Portsmouth v. Weiss, 133 S.E. 781 (Va. 1926):

It is ... an established canon of constitutional construction that no one provision of the [Virginia] Constitution is to be separated from all the others and to be considered alone, but that all of the provisions bearing upon a particular subject are to be brought into view and to be so interpreted as to effectuate the great purpose of the instrument.

Id. at 785 . 
In the context of finding a right to treatment in the least restrictive setting, constitutional provisions that mention a specific right (i.e., privacy) ${ }^{227}$ or a specific group (i.e., the mentally ill) ${ }^{228}$ may prove extremely valuable. Not only do explicit expressions evidence a heightened concern for the group or right in question, but reliance on them may appease conservative jurists who reject the legitimacy of expansive interpretations that rely on more ambiguous and generalized provisions. ${ }^{229}$ Whether based upon textual or historical grounds, ${ }^{230}$ equal protection and due process guarantees that exceed their federal analogs, or are interpreted more liberally in specific key cases, are especially useful tools for advancing the claims proposed here.

\section{APPLiCATIONS OF THE Right TO COMMUNITY-BASED TrEATMENT IN STATE Constitutions}

The discussion up to this point has mapped out the theoretical foundations for the right of the mentally ill to be treated in the least restrictive setting appropriate to their needs. ${ }^{231}$ We have learned that what is most appropriate and what is least restrictive are not mutually exclusive terms, but rather are mutually supportive concepts, indicating the need for, as well as the right of, the mentally ill to be treated in the community. ${ }^{232}$ We have also learned that the source of such a right is not likely to be found in federal statutes, state statutes, or even the U.S. Constitution. ${ }^{233}$

${ }^{227}$ See infra text accompanying notes 313-22.

${ }^{228}$ See infra text accompanying notes 343-56, 403.

${ }^{229}$ See Maltz, supra note 210, at 1013-15 (noting that arguments based on specific language can have a good deal of force).

${ }^{230}$ For example, circumstances surrounding the adoption of the relevant state constitutional provisions, see Developments, supra note 196, at 1361; or a long tradition or commitment to a specific right, see Galie, supra note 209, at 765; or even based upon the general heritage of the state, see Ravin v. State, 537 P.2d 494 (Alaska 1975), where the court, in finding a right to smoke marijuana in the privacy of one's own home, noted:

Our territory and now state has traditionally been the home of people who prize their individuality and who have chosen to settle or to continue living here in order to achieve a measure of control over their own lifestyles which is now virtually unattainable in many of our sister states.

Id. at 504.

${ }^{231}$ See supra text accompanying notes 66-88.

${ }^{232}$ See supra text accompanying notes 104-39.

${ }^{233}$ See supra text accompanying notes 140-92. 
Given that it is "hard to accept that there can be any 'fundamental personal liberty' ... more fundamental than personal liberty, ${ }^{234}$ and given the increased threat to the civil liberties of the mentally ill in the early $1990 \mathrm{~s},{ }^{235}$ the need to find a foundation for protection is imperative. In light of the potentially expansive interpretive opportunities available in state constitutions, this Comment argues that a foundation for the protection of the mentally ill may be found there.

The analysis is divided into two parts. Part V, Section A begins by exploring several substantive due process doctrines that can help advance claims on behalf of the mentally ill for a right to community-based treatment. For each, an underlying theory and strategy is developed, followed by an analysis of potential applications in various states. The presentation is organized around the tools of state constitutional law that would most successfully develop the respective doctrines and render them most effective. These tools include liberally interpreted state due process provisions, privacy provisions in state constitutions, and state constitutional provisions for the mentally ill.

Part V, Section B explores the rights-expanding potential of state equal protection provisions. Beginning with an analysis of equal protection theory, this Part makes two claims. First, the mentally ill should be considered members of a "suspect" class and, therefore, any state action that affects their rights should be strictly construed. Second, because those mentally ill persons who are most at risk of being civilly committed are poor, any state action that deprives them of liberty because of their poverty should be strictly construed.

At work in both the substantive due process and equal protection analyses will be the doctrine of least restrictive means. In the context of substantive due process challenges, the doctrine of least restrictive means will help unearth those civil commitment schemes that in their overbreadth impact upon core constitutional values. In the equal protection challenges, the doctrine will similarly expose overbroad classifications, but classifications that in their overbreadth treat certain groups of individuals with less dignity and respect. For both, it will be shown that an honest and principled application of the least restrictive alternative doctrine would require states to develop effective and appropriate community-based treatment

${ }^{244}$ Chambers, supra note 18, at 1158 (footnote omitted).

${ }^{235}$ See supra text accompanying notes $51-65$. 
services if they wished to preserve the constitutionality of their civil commitment schemes. ${ }^{236}$

\section{A. Substantive Due Process}

The Due Process Clause of the Fourteenth Amendment provides that "[n]o State ... shall deprive any person of life, liberty, or property, without due process of law. ${ }^{\text {237 }}$ While it may, as a matter of semantics, appear to provide more of a procedural than a substantive limitation, courts have used the Due Process Clause to block governmental actions that threaten core constitutional values. ${ }^{238}$ These values, though taking various forms, can be best understood as supporting a unitary conception of liberty. ${ }^{239}$

The genesis of what has come to be termed "substantive due process" dates back to the late nineteenth century. ${ }^{240}$ It was during that time that the Court began to rapidly strike down laws that infringed on basic economic liberties, such as the liberty to contract. ${ }^{241}$ For example, in the case most symbolic of that era, the Supreme Court in Lochner v. New York, ${ }^{242}$ invalidated New York's maximum hours law for bakers on the grounds that it

${ }^{236}$ Although the arguments that follow should be made wherever and whenever possible, arguably all that is needed is for one prominent state court to support a constitutional right to community-based treatment and the rest might soon follow. See Swindler, supra note 214, at 173 (noting how in construing a constitutional provision, decisions of the courts in another state with substantially the same provision will generally be given great weight); $c f$. John P. Hagan, Patterns of Activism on State Supreme Courts, PUBLIUS, Winter 1988, at 97, 113 (noting that generally when one state court becomes activist, it tends to stay activist).

${ }^{237}$ U.S. CONST. amend. XIV, § 1.

${ }^{238}$ See HENRY J. ABRAHAM, FREEDOM AND THE COURT 122 (5th ed. 1988).

${ }^{299}$ See TRIBE, supra note 200, at 553-86, 1302-1435 (detailing the territorial limits of substantive due process review, which include First Amendment liberties of speech, association, and political action, as well as more modern conceptions of autonomy, including the right to privacy).

${ }^{240}$ See ABRAHAM, supra note 238, at 123 (noting, however, that substantive due process may have gotten its first start in Wynehamer v. People, 13 N.Y. 358 (1856) (striking down a New York liquor prohibition)).

241 Abraham notes:

Socio-conomic experimentation by the legislatures, such as minimum-wage, maximum-hour, and child-labor regulations, was regarded with almost unshakable disapproval by a solid majority of the Court. Again and again the justices struck down, as unconstitutional violations of substantive due process of law, legislation that large majorities of both the national and state levels deemed wise and necessary.

Id. at 12.

242198 U.S. 45 (1905). 
interfered with both the bakers and the bakers' employers' ability to contract freely. As was the case in Lochner, an invocation of substantive due process meant that the courts would closely scrutinize both the ends sought and means employed in challenged economic and social legislation, analyzing with profound skepticism the decisions made by experts and professionals. ${ }^{243}$ This secondguessing of progressive ${ }^{244}$ legislation continued virtually unabated into the 1930s when what has been dubbed the "Lochner era" came to an abrupt halt. ${ }^{245}$

Whether it was internal inconsistencies in applying the substantive due process doctrine or the economic and political exigencies engendered by the Great Depression, ${ }^{246}$ governmental involvement in the form of socioeconomic assistance and protection became more widely accepted by the Court. ${ }^{247}$ Liberty, in fact, came to be seen as requiring governmental action, not merely governmental abstention. Alternatively, infringement on non-economic rights, particularly social and political rights, received more judicial scrutiny than ever before. ${ }^{248}$ Thus, it was now governmental infringements on personal autonomy, personhood, and privacy that demanded strict scrutiny review. ${ }^{249}$ Substantive due process had essentially reconfigured itself into a more progressive conception of political liberalism. The "right to be let alone," not the "liberty to contract," became the clarion call of modern substantive due process jurisprudence.

In applying this modern conception of substantive due process, courts have traditionally engaged in a three-part analysis: assessing the compellingness of the government's objective, the liberty interests sacrificed in furthering that objective, as well as the

243 See TRIBE, supra note 200 , at $565-74$.

24 For a general discussion of the Progressive era, see 1 ARTHUR S. LINK ET AL., AMERICAN EPOCH: A HISTORY OF THE UNITED STATES SINCE 1900, at 44-100 (1987).

245 For most Court commentators, 1937 marks the moment when the Court officially ended its Lochner-era jurisprudence. See ABRAHAM, supra note 238, at 13 (discussing President Roosevelt's court-packing plan and the "switch in time that saved nine'"); TRIBE, supra note 200, at 574-81 (discussing several factors, both internal to the Court and external to it, that contributed to the Court's jurisprudential switch). For a more historical perspective, see WILLIAM E. LEUCHTENBURG, FRANKLIN D. ROOSEVELT AND THE NEW DEAL 231-39 (1963).

${ }^{245}$ See TRIBE, supra 200, at 574-78.

247 See ABRAHAM, supra note 238, at 18-19.

${ }^{248}$ See United States v. Carolene Prods. Co., 304 U.S. 144, 152-53 n.4 (1938); ABRAHAM, supra note 238, at 14 .

${ }^{249}$ See ABRAHAM, supra note 238, at 124; TRIBE, supra note 200, at 1302-1435. 
neatness of fit between means and ends. ${ }^{250}$ This third prong of the test is the least restrictive alternative doctrine.

As you may recall from our earlier discussion, the doctrine requires that governmental purposes not be pursued by means that broadly stifle fundamental personal liberties when the ends can be more narrowly achieved. ${ }^{251}$ If the scope of the deprivation is "completely unlimited," 252 or as Tribe characterizes it, "substantially overbroad," 253 the government almost by definition must use less restrictive alternatives if it wishes to preserve its legislative scheme. The least restrictive alternative doctrine becomes, in other words, the central constitutional standard by which regulations substantially depriving individuals of core constitutional rights are adjudged. Not merely a tool with which constitutional violations are unearthed, the doctrine takes us one step further, delineating the requirements for legislative survival. ${ }^{254}$

In the context of mental health law, the doctrine of least restrictive alternatives, as this author envisions it, would require the state to develop effective alternatives to institutionalization. ${ }^{255}$ If the state is to constitutionally carry on its dual objectives of treating the mentally ill, while ensuring public safety, it cannot do so by employing the most liberty-restricting means-institutionalization. ${ }^{256}$ That there are other less-restrictive alternatives by which the mentally ill can be treated and society protected requires that the state adopt these alternatives if its legislative scheme is to survive substantive due process review.

That those means may not have yet been developed and funded by the state should not matter. Community-based treatment services envisioned as being a less restrictive alternative to institutionalization do, in fact, exist. A fair application of the doctrine of

${ }^{250}$ See, e.g., Roe v. Wade, 410 U.S. 113, 155 (1973) (infringement must be narrowly drawn so as to pursue only a compelling state interest); Griswold v. Connecticut, 381 U.S. 479, 485 (1965) (same).

${ }^{251}$ See Shelton v. Tucker, 364 U.S. 478, 488 (1960); see also supra notes 67-68 and accompanying text.

252 Shelton, 364 U.S. at 488.

${ }^{253}$ TRIBE, supra note 200 , at 1037.

254 This version of the least restrictive alternative doctrine is to be contrasted with its use in equal protection jurisprudence, where the doctrine helps unearth the more invidious characteristics of a given legislative scheme. See infra text accompanying note 361 .

${ }^{255}$ See supra text accompanying notes 78-83.

${ }^{256}$ See Humphrey v. Cady, 405 U.S. 504, 509 (1972) (characterizing civil commitment as a "massive curtailment of liberty"). 
least restrictive alternatives should therefore obligate the states to bring these services within their jurisdictions. The right to have the state consider all appropriate alternatives before choosing institutionalization (a right implicit in many state legislative schemes) would continue to be an empty right unless and until what the state is required to consider actually exists.

\section{Reliance on Expansively Interpreted State Due Process Provisions}

In applying the lowest level of scrutiny to decisions regarding the treatment of the mentally disabled, the Supreme Court in Youngberg v. Romeo ${ }^{257}$ made it known that federal courts might not be as friendly a forum for the mentally ill as they had been in the past. ${ }^{258}$ The Supreme Court subjected each of the plaintiff's due process claims to rational basis review, effectively letting mental health professionals decide whether fundamental liberty interests should be sacrificed or not. ${ }^{259}$

Assuming one wants to challenge a state's incursion into the liberty interests of the mentally ill, a tool for reversing Youngberg's presumption of correctness is needed. Instead of rational basis review, the courts should be subjecting these legislative schemes to the strictest scrutiny possible. This would ensure that the means employed by the states were the least restrictive means used to further the states' objectives. If they were not, that is, if the means employed were not necessary to achieve the states' goals, the civil commitment scheme would be rendered unconstitutional and only the creation of community-based services could save it. Although there are several tools available for reversing this presumption, ${ }^{260}$ we begin here with states that have interpreted their due process provisions more liberally than the federal analog.

Consider, for example, State v. Robb. ${ }^{261}$ Robb concerned the constitutional claims of Harlan Robb, an insanity acquittee who in

${ }^{257} 457$ U.S. 307 (1982); see also supra notes $164-72$ and accompanying text.

${ }^{258}$ See id. at 324 (holding that although the involuntarily committed "enjoy[] . . . constitutionally protected interests in ... reasonably nonrestrictive confinement conditions," decisions made by "appropriate professional[s]" with regard to those conditions are entitled to a presumption of correctness).

${ }^{259}$ See id. at $320-22$. The Court noted that ${ }^{\circ}[\mathrm{b}] \mathrm{y}$ so limiting judicial review of challenges to conditions in state institutions, interference by the federal judiciary with the internal operation of these institutions should be minimized." Id. at 322.

${ }^{260}$ See infra parts V.A.2, 3.

261484 A.2d 1130 (N.H. 1984). 
1972 was committed to the New Hampshire Hospital for the murder of his mother. ${ }^{262}$ For ten years, Robb was periodically recommitted on the basis of court findings that he was still dangerous and mentally ill. In 1982, the New Hampshire legislature amended its recommittal statute to make commitments easier. Under the new standard, if mental health professionals determined that an insanity acquittee's mental condition had not substantially changed from the time when the original criminal act was first perpetrated, the court was required to find that the defendant was still dangerous. ${ }^{263}$ In 1983, Robb was recommitted under the amended law, despite "considerable disagreement among medical experts regarding the defendant's condition, ${ }^{264}$ and no current evidence of dangerous behavior.

On appeal, the New Hampshire Supreme Court accepted the proposition that past acts may support an inference of potential dangerousness, but nevertheless held the amended statute unconstitutional as a violation of the state's due process clause. ${ }^{265}$ Recommitment of an insanity acquittee solely on the basis of evidence of past dangerous acts, without enabling the court to consider more recent, mitigating evidence, placed too much power in the hands of the mental health professionals. Noting that "psychiatric opinions are far from infallible,' ${ }^{266}$ the court reiterated its holding from an earlier case that the "determination of mental disease and dangerousness are matters for the trial court to decide and that the opinions of experts are not necessarily dispositive." 267

Contrasted with the Supreme Court's holding in Youngberg, which constitutionalized virtually absolute deference to the decisions of mental health professionals, ${ }^{268}$ the $R o b b$ decision evidenced a greater distrust of the commitment process, and concomitantly a greater concern for the rights of the mentally ill and disabled. New Hampshire, however, is not alone. In several other states, decisions concerning various dimensions of the commitment process have similarly advanced the rights of the mentally ill well beyond the federal minima. For example, a host of states have interpreted their due process clauses to require more evidentiary proof for civil

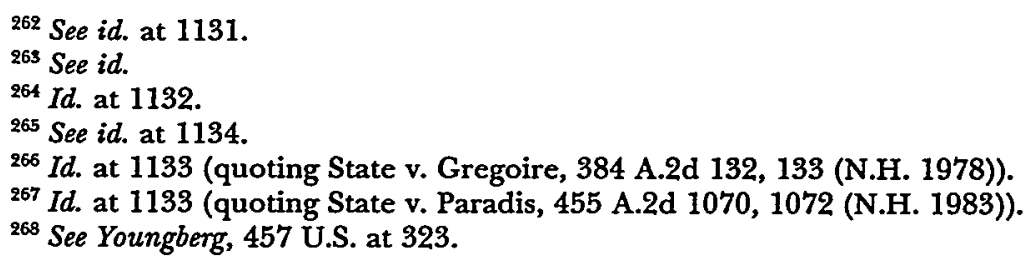


commitment than that required under the federal Constitution. ${ }^{269}$ Other states have rendered their constitutions a source of expansive rights-protection for the currently institutionalized and generally subjected commitment schemes to strict judicial scrutiny. ${ }^{270}$ Others in dicta have expressed a strong preference for less restrictive means of treating the mentally ill and have arguably constitutionalized the right to community-based treatment. ${ }^{271}$ Still others

${ }^{269}$ See, e.g., Heap v. Roulet, 590 P.2d 1, 7 (Cal. 1979) (mandating a "beyond a reasonable doubt standard" for civil commitment, and rejecting the federal "clear and convincing" standard enunciated in Addington v. Texas, 441 U.S. 418, 418 (1978)); In re Pickles, 170 So.2d 603, 614 (Fla. Dist. Ct. App. 1965) (same); Denton v. Commonwealth, 383 S.W.2d 681, 682 (Ky. 1964) (same); State v. O'Neill, 545 P.2d 97, 101 (Or. 1976) (same). Note that recently the United States Supreme Court upheld Kentucky's “beyond a reasonable doubt” standard. See Heller v. Doe, 113 S. Ct. 2637, 2641 (1993).

${ }_{270}$ See, e.g., Fasulo v. Arafeh, 378 A.2d 553, 554, 556-57 (Conn. 1977) (invoking the strict scrutiny requirement of "necessity" in ruling that Connecticut's due process clause mandated that involuntarily civilly committed patients be granted periodic judicial review of the propriety of their confinement); Cooper v. Morin, 399 N.E.2d $1188,1191-92,1195$ (N.Y. 1979) (holding that while contact visitations for pretrial detainees are not constitutionally mandated under the federal Constitution, they are under New York's constitution, and cannot be circumvented by economic considerations), cert. denied, 446 U.S. 984 (1980); cf. Rivers v. Katz, 495 N.E.2d 337, 341, 344 (N.Y. 1986) (holding forced medication of an institutionalized mental patient to be violative of the state's due process clause, and obligating the state to prove that the "proposed treatment is narrowly tailored to give substantive effect to the patient's liberty interest, taking into consideration ... any less intrusive alternative treatments"); Kesselbrenner v. Anonymous, 305 N.E.2d 903, 905, 907 (N.Y. 1973) (ruling that the placement of a non-criminal, though dangerous, mentally ill patient in a correctional facility, as opposed to a mental hospital, violated the state's due process clause, and that the lack of staff or facilities cannot justify subjecting "a person to a greater deprivation of personal liberty than necessary"). See generally Burnor v. State, 829 P.2d 837, 839 (Alaska Ct. App. 1992) (noting that Alaska's due process clause confers broader protection than its federal counterpart); State v., Bernades, 795 P.2d 842, 843 (Haw. 1990) (similarly noting that Hawaii's due process provisions are not necessarily limited to that provided by the Fourteenth Amendment); Cootz v. State, 785 P.2d 163, 165 (Idaho 1989) (noting the independence of Idaho's due process provision from the federal provision).

${ }^{271}$ See, e.g., 491 N.W.2d 508, 512 (Iowa 1992) (noting that "[i]t is not only the customary procedure, but the constitutionally and statutorily mandated requirement, to treat even seriously mentally impaired persons in the least restrictive environment medically possible," and holding that the State hospital cannot be held liable for the actions of the recently deinstitutionalized (emphasis added)); Hawks v. Lazaro, 202 S.E.2d 109, 123 (W. Va. 1974) (noting that "community mental health facilities ... [make it] possible for many nonviolent people . . . to live outside of an institution, and when these people prefer to do so, ... the constitution guarantees them the right to follow their own desires," and holding the state's "in need of treatment" standard for civil commitment to be overbroad and violative of the due process clause of the state constitution (emphasis added)); $(f$. McGraw v. Hansbarger, 301 S.E.2d 857, 860 (W. Va. 1983) (requiring the state to finance and create a detoxification and 
have liberally interpreted their civil commitment statutes to advance community-based placements, without reference to their state's due process provisions. ${ }^{272}$

In each of these jurisdictions, the courts have evidenced a heightened concern for the liberty interests of the institutionalized, the deinstitutionalized, or those "at risk" of being institutionalized. Individuals seeking support (financial or otherwise) for communitybased alternatives to civil commitment should thus find these states particularly amenable to their substantive due process claims. In contrast to the minimalist scrutiny employed in Youngberg, these jurisdictions have recognized the risks involved when the government extends its paternalistic reach. As noted in this Comment's epigraph, "[e]xperience should teach us to be most on our guard to protect liberty when the Government's purposes are beneficent." 273 But in Youngberg, instead of focusing on the liberty concerns implicated by civil commitment schemes, the Court

alcoholism treatment program on the basis of a statutory provision requiring the consideration of alternative, community treatment programs, as well as on Article X, $\S 3$ of the West Virginia Constitution, which provides that money cannot be taken from the Treasury "for any other purpose than that which it has been or may be appropriated"). Note that the timing of when to order or not to order communitybased alternatives is often crucial. As the West Virginia Supreme Court held last winter, if the legislature has already decided to spend its money one way, the court should not try to change its funding priorities. See E.H. v. Matin, 428 S.E.2d 523, 526 (W. Va. 1993) (relying on state separation of powers principles for the conclusion that the state court should not involve itself in enjoining the construction of a new mental hospital because it would rather have the money spent on community treatment centers).

272 See, e.g., In re S.L., 462 A.2d 1252, $1257-59$ (N.J. 1983) (interpreting broadly the state commitment statute to allow for a court-created class of individuals for whom the state is required to make good faith efforts to find less restrictive alternatives to institutionalization, and noting more generally that the "civil commitment process must be narrowly circumscribed because of the extraordinary degree of state control it exerts over a citizen's autonomy" (emphasis added)); State v. Carter, 316 A.2d 449, 453,457 (N.J. 1974) (holding that an insanity acquittee should not be prevented from participating in conditional release programs more traditionally used by the civilly committed, and noting that the difficulty of achieving a balance between the individual's and the public's rights cannot serve as an excuse for failing to "integrat [e] the mentally ill back into the mainstream of society"), overruled on other grounds by State v. Krol, 344 A.2d 289 (1975); In re W.H., 481 A.2d 22, 25-26 (Vt. 1984) (interpreting state statute to require a consideration of all "feasible less restrictive alternatives" before an individual may be forcibly detained for an emergency psychiatric evaluation, and noting that " $[t]$ he best interests of the mentally ill lie more often than not in treatment that does not involve commitment" (quoting In re Harris, 654 P.2d 109, 115 (Wash. 1982))); cf. In re Schmidt, 429 A.2d 631, 636-37 (Pa. 1981) (broadly construing statutory language to require the state to expend the funds necessary to build facilities appropriate to the needs of the mentally disabled).

${ }^{273}$ Olmstead v. United States, 277 U.S. 438, 479 (1928) (Brandeis, J., dissenting). 
presumably chose to see only the social welfare dimension of these statutes. In doing so, the Court anchored its analysis of the substantive due process claims to a post-Lochner era jurisprudence of "rational basis" review, ${ }^{274}$ thereby ensuring that "social and economic legislation" of this sort would survive constitutional challenges. ${ }^{275}$ Alternatively, by classifying these due process challenges as liberty claims and not merely as challenges to social welfare legislation or to the states' police powers, state courts have subjected these legislative schemes to strict judicial scrutiny. But even this "recharacterization" of the constitutional claim may not be necessary. Over the past two decades, there has been a resurgence of Lochner-style jurisprudence, as state courts have with increasing frequency applied a strict scrutiny standard of review to traditional economic legislation. ${ }^{276}$

Consider, for example, Pennsylvania State Board of Pharmacy $v$. Pastor. ${ }^{277}$ In Pastor, the Pennsylvania Supreme Court held unconstitutional an economic regulation that forbade pharmacists from advertising the prices of dangerous or narcotic drugs. Noting that the Supreme Court would not substitute its social and economic beliefs for the judgment of the legislative bodies, the Pennsylvania

274 See ABRAHAM, supra note 238, at 13-14; TRIBE, supra note 200, at 578-86.

275 See id. at 583; see also Dandridge v. Williams, 397 U.S. 471, 484, 487 (1969) (upholding Maryland's AFDC grant regulations which impose a ceiling on benefits regardless of family size and actual need, and noting that "state regulation in the social and economic field [does] not affect[] freedoms guaranteed by the Bill of Rights" and thus "are not the business of [the] Court" (emphasis added)); West Coast Hotel Co. v. Parrish, 300 U.S. 379, 391-92 (1937) (upholding Washington state's minimum wage law for women and minors and noting that liberty under the Due Process Clause is subject to police power regulations adopted in the interest of the community).

${ }^{276}$ See, e.g., Friday v. Ethanol Corp., 539 So.2d 208, 215-16 (Ala. 1988) (holding Alabama's requirement that dealers of gasohol label all their products with the words "gasohol" written in three-inch type to be a violation of the state's due process provisions, and noting that legislatures cannot pursue means "that broadly stifle fundamental personal liberties when the end can be more narrowly achieved" (citing Shelton v. Tucker, 364 U.S. 479, 488 (1960) (applying the overbreadth doctrine to regulations affecting one's right to free expression))); In re Aston Park Hosp., Inc., 193 S.E.2d 729, 735 (N.C. 1973) (holding state regulations that required hospitals operating on private property and with private funds to obtain a certificate of need from the state an unconstitutional infringement of the state's due process provisions, and noting that "'[i]f a statute is to be sustained as a legitimate exercise of the police power . . . it must be reasonably necessary to promote the accomplishment of a public good, or to prevent the infliction of a public harm" (emphasis added) (quoting State v. Ballance, 51 S.E.2d 731, 735 (N.C. 1949))).

277272 A.2d 487 (Pa. 1971). 
court clearly distanced itself from post-Lochner jurisprudence. ${ }^{278}$ The court, in fact, challenged the policy assumptions underlying each of the state's asserted rationales, detailing alternatives that would bear a more substantial relationship to the avowed goal of diminishing the demand for narcotics. ${ }^{279}$

Given the willingness of courts, like Pennsylvania's, to engage in strict judicial scrutiny of economic regulations, at least an equal level of scrutiny may be expected for decisions affecting personal, and not merely economic, freedoms. As already noted, social and economic regulations have traditionally been subjected to the same level of "rational-basis" review in the post-Lochner age. ${ }^{280}$ Therefore, if a state applies a more searching review of "economic" rights (à la Lochner), it should also be compelled to more searchingly review "social welfare" legislation, such as state civil commitment procedures. Although economic conservatism may be the motivating force behind many of these state court decisions, only the most unprincipled of courts would not extend their skepticism to social legislation.

Whether civil commitment is primarily characterized as an infringement of core, fundamental values, such as liberty and autonomy, or as social welfare legislation designed to help a needy class of individuals, the opportunity to subject these statutes to strict scrutiny review is equally available. In terms of advancing constitutional claims to community-based alternatives to civil commitment, resort to state due process provisions and the doctrine of least restrictive means provides at least one avenue through which litigants should travel.

\section{Privacy Provisions in State Constitutions and the} Doctrine of Unconstitutional Conditions

A second due process argument for requiring the state to provide community-based treatment for the mentally ill could be conceptually grounded in the doctrine of "unconstitutional conditions." 281 Developed most notably in the "abortion funding"

278 See id. at $490-91$.

279 See id. at 492-93 (citing Florida Bd. of Pharmacy v. Webb's City, Inc., 219 So. 2d 681 (Fla. 1969) (applying the same level of scrutiny to its own state constitution); Guy M. Struve, The Less-Restrictive Alternative Principle and Economic Due Process, 80 HARV. L. REV. 1463, 1472 (1967)).

${ }^{280}$ See supra note 275 and accompanying text.

${ }^{281}$ For a general discussion of the doctrine, see Kathleen M. Sullivan, Unconstitutional Conditions, 102 HARV. L. REv. 1413, 1415 (1989) (describing the doctrine of 
cases, ${ }^{282}$ the doctrine can be anchored to the privacy provisions of state constitutions to provide a right to community-based treatment for those who voluntarily seek treatment from the state.

For most judges, it is clear that "when a state decides to alleviate some of the hardships of poverty by providing medical care, the manner in which it dispenses benefits is subject to constitutional limitations." 283 What those limitations are, however, is less clear. For the mentally ill who must resort to the state for assistance, or have the state assert itself on their behalf, the "hardships of poverty" have made them particularly vulnerable recipients of state aid. Most of those voluntarily or involuntarily committed to state mental hospitals could not afford private forms of treatment, and could not make use of community alternatives that did not exist. ${ }^{284} \mathrm{Al}$ though states are arguably not obligated to assist the mentally ill, the decision to provide assistance, but only in the form of civil commitment, goes beyond the constitutional limitations established to preserve individual liberty. States that have not developed effective community-based services have thus essentially conditioned the receipt of medical assistance upon the willingness of the mentally ill to relinquish their fundamental rights. For those who are trying to make a choice between receiving the only form of aid available-inpatient treatment-and receiving no aid at all, the cards are clearly stacked against them: either choose aid and lose liberty, or choose liberty and lose aid. And if one assumes that illness diminishes an individual's freedom of action, choosing liberty may ultimately undermine the liberty chosen. ${ }^{285}$

unconstitutional conditions as forbidding government to "grant a benefit on the condition that the beneficiary surrender a constitutional right, even if the government may withhold that benefit altogether"). Sullivan critiques the current Court's analysis for lacking consistency and suggests her own doctrinal formulation of "unconstitutional conditioning," which would require the application of a strict scrutiny analysis to a broader array of cases. Id. at 1489-1505.

${ }^{282}$ See, e.g., Harris v. McRae, 448 U.S. 297 (1980); Maher v. Roe, 432 U.S. 464 (1977).

${ }^{28 s}$ Maher, 432 U.S. at $469-70$.

${ }^{284}$ See Richard Rapson, The Right of the Mentally IIl to Receive Treatment in the Community, 16 CoLum. J.L. \& Soc. PROBS. 193, 240 (1980) (noting that the "absence of affordable . . . community treatment services may present a mentally ill individual with no realistic alternative to seeking care from the state").

${ }^{285}$ This line of reasoning cannot, of course, be extended to the involuntarily committed. Only those who seek treatment voluntarily are forced to choose between freedom and treatment. See, e.g., R.I. GEN. LAws $\$ 40.1-5-6(2)$ (1990) ("If it is determined that the applicant [for voluntary admission] is in need of care and treatment . . . and no suitable alternatives to admission are available, he or she shall 
Arguments analogous to these have already been made before the Supreme Court. In the context of welfare assistance, however, the Court has generally rejected them. ${ }^{286}$ At issue in the "abortion funding" cases was whether the government violated a due process liberty right by limiting the use of Medicaid funds to reimburse the costs of childbirth, but not abortions. Although the case of Maher v. $R o e^{287}$ rested on an interpretation of the Equal Protection Clause, Harris v. McRae ${ }^{288}$ directly confronted the substantive due process claim of unconstitutional conditioning, and rejected it. ${ }^{289}$ The Court noted that the Hyde Amendment, which withheld Medicaid assistance to reimburse the costs of medically necessary abortions, had not imposed a restriction on access to abortions that did not already exist. ${ }^{290}$ Consequently, the Court refused to require the state to remove those restrictions "not of its own creation. ${ }^{291}$ Although the state had assumed the responsibility of assisting the indigent sick, and thus should have been subjected to what the Court had characterized in Maher as "constitutional limitations," $" 292$ the Court allowed the state to "ride roughshod" over fundamental liberty interests. ${ }^{293}$

be admitted for a period not to exceed thirty days."); S.D. CODIFIED LAWS ANN. $\S 27 A-8-1(2)$ (1992) ("The facility . . . may receive . . . a voluntary patient . . . if . . . [a] less restrictive treatment alternative is inappropriate or unavailable."). The involuntarily committed will receive a state benefit whether they want it or not; for them, there is no real sense of conditioning the receipt of a benefit on a abdication of fundamental rights. As Sullivan describes it, "[b]y its very nature, the doctrine serves to protect only those rights that depend on some sort of exercise of autonomous choice by the rightsholder." Sullivan, supra note 281, at 1426. Nevertheless, with the exception of deciding which party to argue the right for, the voluntary/involuntary distinction should as a practical matter be irrelevant. That is, whether the right to community-based treatment hinges on the voluntarily committed or the involuntarily committed, the acceptance of such a right by the courts would still translate into the development of community alternatives.

286 See Sullivan, supra note 281, at 1417 (noting that with the exception of having held unconstitutional the denial of unemployment compensation to Saturday sabbatarians, "the Court has rejected every other claim that conditions on food stamps or welfare payments unconstitutionally burden" fundamental liberties).

${ }^{287} 432$ U.S. 464 (1977).

288448 U.S. 297 (1980).

${ }^{289}$ See id. at $312-18$.

290 See id. at 317 (noting that the "Hyde Amendment leaves an indigent woman with at least the same range of choice in deciding whether to obtain a medically necessary abortion as she would have had if Congress had chosen to subsidize no health care costs at all").

${ }^{291} I d$. at 316.

${ }^{292}$ Maher, 432 U.S. at 470.

293 Harris, 448 U.S. at 331 n.4 (Brennan, J., dissenting). 
Turning to state courts and interpretations of their own state constitutions, the concept of "unconstitutional conditioning" has been more favorably received. In Committee to Defend Reproductive Rights v. Myers, ${ }^{294}$ for instance, the California Supreme Court held that California's budgetary provisions, limiting Medi-Cal funding for abortions, was an unconstitutional infringement of fundamental liberty. ${ }^{295}$ Contrasting its own decision to the Supreme Court's in Harris v. McRae, the California court reasoned that the "explicit constitutional status" of privacy in the California Constitution affords the individual greater protection than the federal constitutional right. ${ }^{296}$ Following a lengthy discussion of the independent grounds upon which California state constitutional provisions are to be interpreted, ${ }^{297}$ the court applied the doctrine of "unconstitutional conditions, ${ }^{298}$ noting that:

[a]lthough the state has no constitutional obligation to provide medical care to the poor, a long line of California decisions establishes that once the state has decided to make such benefits available, it bears a heavy burden of justification in defending any provision which withholds such benefits from otherwise qualified individuals solely because they choose to exercise a constitutional right. ${ }^{299}$

${ }^{294} 625$ P.2d 779 (Cal. 1981).

295 See id. at 798.

${ }^{296} I d$. at 784 . California's privacy provision provides that "[a]ll people are by nature free and independent and have certain inalienable rights. Among these are enjoying and defending life and liberty, acquiring, possessing and protecting property, and pursuing and obtaining safety, happiness and privacy." CAL. CONST. art. I, § 1 .

Several other state courts have come down with similar decisions, interpreting their state constitutions more liberally, even without the additional justification of having an explicit privacy provision in their state constitution. See Doe v. Maher, 515 A.2d 134, 135, 148-51 (Conn. Super. Ct. 1986) (basing its decision on its due process clause and a right of privacy implicit in that clause); Moe v. Secretary of Admin. \& Fin., 417 N.E.2d 387, 402 (Mass. 1981) (holding that the government's funding restriction burdens the fundamental right to choice); Right to Choose v. Byrne, 405 A.2d 427, 431 (N.J. Super. Ct. Ch. Div. 1979) (noting that one's health is a fundamental liberty which is shielded by Article I, Paragraph 1 of the New Jersey Constitution which prohibits unreasonable and discriminatory restrictions); Hope v. Perales, 571 N.Y.S.2d 972, 976-80 (Sup. Ct. 1991) (relying in part on the privacy rights implicit in its due process clause), affd, 595 N.Y.S.2d 948 (App. Div. 1993); Planned Parenthood Ass'n v. Department of Human Resources, 663 P.2d 1247, 1257-59 (Or. Ct. App. 1983) (holding that a rule limiting state medical assistance for abortions violated Oregon's privileges and immunities provision), affd, $687 \mathrm{P} .2 \mathrm{~d} 785$ (Or. 1984).

${ }^{297}$ See Myers, 625 P.2d at 783-84.

298 Id. at 787.

${ }^{299} I d$. at 784. 
The court then subjected the budgetary provisions to a traditional three-part (strict scrutiny) test, requiring the state to demonstrate "(1) 'that the imposed conditions relate to the purposes of the legislation which confers the benefit or privilege'; (2) that the 'utility of imposing the conditions ... manifestly outweigh[s] any resulting impairment of constitutional rights'; and (3) that there are no 'less offensive alternatives available for achieving the state's objective."'300 The court concluded that the state had failed to satisfy each of the three parts. ${ }^{301}$ Several years after Myers, the California Supreme Court confronted yet another "unconstitutional conditions" claim, but one which more closely parallels the civil commitment analogy.

In Robbins v. Superior Court, ${ }^{302}$ the California Supreme Court addressed the issue of whether state regulations requiring a welfare recipient to reside in an institutional facility in lieu of cash benefits violated the state's privacy provisions. ${ }^{303}$ The court began its analysis by first clarifying what the right to privacy included. Arguing that it encompassed a variety of rights involving private choices in personal affairs, the court capsulized the right as "the right to be left alone, $" 304$ and included within it Robbins's interests in not being forced into a welfare facility as a condition for welfare support. $^{.05}$

In determining whether Robbins's right had been violated by the County's regulations, the court applied the same three-part test used in Myers, noting that "[w]hen receipt of a public benefit is conditioned upon the waiver of a constitutional right, 'the government bears a heavy burden of demonstrating the practical necessity for the limitation." ${ }^{\text {306 }}$ Holding that the county had failed to satisfy the third, or "less restrictive alternative," prong of the Myers's test, the court cited several less restrictive alternatives to involuntarily confining individuals in welfare institutions. ${ }^{307}$ Among the alter-

${ }^{300}$ Id. at 781 (quoting Bagley v. Washington Township Hosp. Dist., 421 P.2d 409, 414-15 (Cal. 1966)).

${ }^{301}$ See id. at 790-98.

${ }^{302} 695$ P.2d 695 (Cal. 1985).

${ }^{303}$ See id. at 703 .

${ }^{304} \mathrm{Id}$. at 703.

${ }^{305}$ See id. at 707. Effective October 1, 1982, applicants were given the choice of either residing in the institutional facility, an emergency shelter, or foregoing benefits. See id. at 697 .

${ }^{306} \mathrm{Id}$. at 704 (citation omitted).

${ }^{307}$ See id. at 705. 
natives mentioned by the court was the proposal that the county construct low-income housing. ${ }^{308}$ Noting that it was not "unmindful of the budgetary constraints facing counties," the court nonetheless held that "financial considerations cannot justify an infringement of a basic constitutional right absent a showing that no less onerous cost-cutting methods are available." 309 The court remanded the case instructing the trial court to preliminarily enjoin the state from imposing this condition on Robbins's receipt of state support. ${ }^{310}$

In Robbins, unlike in Myers, the court tackled head-on the issue of funding. While financial considerations were an element in the court's balancing in Myers, the court was able to argue that requiring the state to also fund abortions would ultimately save the state money. ${ }^{311}$ In Robbins, however, the alternatives envisioned actually presented a serious financial burden for the state. Undaunted, the court was willing to suggest that even if the costs were heavy, constitutional concerns were weightier. In both cases, therefore, the privacy provisions of the California state constitution provided the conceptual link needed to advance constitutional claims of "unconstitutional conditioning" well beyond where the U.S. Supreme Court was willing to go. As a strategy for advancing the claim that the voluntarily committed mentally ill are constitutionally entitled to community-based treatment alternatives, its applicability, at least in California, is eminently clear.

As a general matter, focusing on state constitutional provisions that recognize a specific right, such as privacy, is a commonly used stratagem of state constitutionalism. ${ }^{312}$ A source of greater rights protection in California for those making the substantive due process claims argued for above, the privacy provisions of other state constitutions ${ }^{313}$ provide similarly expansive rights-developing

\footnotetext{
${ }^{308}$ See id.

${ }^{309} I d$. at 707.

${ }^{310}$ See id.

${ }^{311}$ See Myers, 625 P.2d at 794.

${ }^{312}$ See supra text accompanying notes 227-29.

313 Ten states have explicit privacy provisions. Five of the 10 (Alaska, California, Florida, Hawaii, and Montana) are distinct from the constitutions' search and seizure provisions, implying an even broader conception of privacy. See ALASKA CONST. art. I, § 22; CAL. CoNST. art. I, § 1; FLA. CONST. art. I, \$§ 12, 23; HAW. CoNST. art. I, § 6; MONT. CONST. art. II, $\S 10$. The other five are more traditional search and seizure type provisions. See ARIz. CoNST. art. II, § 8; ILI. CoNST. art. I, §§ 6, 12; LA. CoNST. art. I, § 5; S.C. CONST. art. I, § 10; WASH. CONST. art. I, § 7.
} 


\section{opportunities. Alaska, ${ }^{314}$ Arizona, $^{315}$ Florida, $^{316}$ Hawaii, ${ }^{317}$}

Several states without privacy provisions have also chosen to read a right to privacy into other provisions of their state constitutions. See, e.g., State v. Thompson, 760 P.2d 1162, 1164 (Idaho 1988) (interpreting privacy rights under search and seizure claims more liberally than federal analog). In fact, in the mental health context, several states have progressively furthered a patient's right to refuse certain types of treatment. See, e.g., In re Schmidt, 443 N.W.2d 824, 827 (Minn. 1989) (noting that intrusive forms of medical treatment of the medically ill could conceivably violate a right to privacy implicit in article $I, \S \S 1,2$, and 10 of the Minnesota Constitution). The court further acknowledged that Minnesota's Constitution "may afford mentally ill involuntarily committed patients greater privacy and due process procedural protections than does the federal constitution." Id.; see also Jarvis v. Levine, 418 N.W.2d 139, 148-49 (Minn. 1988) (holding that involuntary treatment with neuroleptic drugs can only be justified if it is the least drastic means available for furthering a compelling state interest, deciding the case on the basis of privacy rights under the Minnesota Constitution). The court in Jarvis noted that under Minnesota law "[n]o right is held more sacred, or is more carefully guarded, by the common law, than the right of every individual to the possession and control of his own person, free from all restraint or interference of others, unless by clear and unquestionable authority of law." Id. at 149. (quoting Minnesota Bd. of Health v. City of Brainerd, 241 N.W.2d 624 (Minn.), appeal dismissed, 429 U.S. 803 (1976)).

For a general discussion of the use of privacy provisions in state constitutionalism, see Gerald B. Cope, Jr., Note, Toward a Right of Privacy as a Matter of State Constitutional Law, 5 FLA. ST. U. L. REv. 631, 690-92 (1977).

${ }^{314}$ See Ravin v. State, 537 P.2d 494, 504 (Alaska 1975) (using the state's privacy provision to allow the personal consumption of marijuana); Breese v. Smith, 501 P.2d $159,171-72$ (Alaska 1972) (using the state's privacy provision to allow the wearing of long hair in public schools). Alaska's privacy provision provides that "the right of the people to privacy is recognized and shall not be infringed." ALASKA CONST. art. I, $\$ 22$.

${ }^{315}$ See State v. Ault, 724 P.2d 545, 552 (Ariz. 1986) (interpreting the Arizona search and seizure provision more liberally than federal analog); State v. Wedding, 831 P.2d 398, 406 (Áriz. Ct. App. 1992) (noting that the Arizona Supreme Court has in limited instances interpreted the Arizona provision more liberally than the federal version). The Arizona search and seizure provision establishes that "[n]o person shall be disturbed in his private affairs, or his home invaded, without authority of law." ARIZ. CONST. art. II, $\S 8$.

${ }^{316}$ See In re T.W., 551 So. 2d 1186, 1190-91, 1196 (Fla. 1989) (holding a parental consent requirement for minors seeking abortions unconstitutional and stating its intention to interpret the state constitution's privacy provisions more expansively than the Supreme Court's interpretation under federal law); see also In re Browning, 568 So. 2d 4, 15 (Fla. 1990) (upholding the use of "living wills" under $\$ 23$ of the Florida Constitution). Article I, $\S 23$ provides that "[e]very natural person has the right to be let alone and free from governmental intrusion into his private life except as otherwise provided herein. This section shall not be construed to limit the public's right of access to public records and meetings as provided by law." FLA. CONST. art. I, § 23.

${ }^{317}$ See State v. Kam, 748 P.2d 372, 379 (Haw. 1988) (using the state constitution's privacy provision to forbid the criminalization of pornography distribution, and reasoning that an "adult person cannot read or view pornographic material in the privacy of his or her own home if the government prosecutes the sellers of pornography"). The court also noted that "in view of the important nature of this 
Louisiana, ${ }^{318}$ Montana, ${ }^{319}$ South Carolina, ${ }^{320}$ and Washington $^{321}$ have each, in varying degrees, used their state constitutional

right, the State must use the least restrictive means should it desire to interfere with the right." Id. at 378 (quoting STANDING COMM. REP. No. 69, reprinted in 1 PROCEEDINGS OF THE CONSTITUTIONAL CONVENTION OF HAWAII OF 1978, at 674-75 (1980)). The privacy provision in Hawaii provides that " $[t]$ he right of the people to privacy is recognized and shall not be infringed without the showing of a compelling state interest. The legislature shall take affirmative steps to implement this right." HAW. CONST. art. I, §6.

${ }^{318}$ See State v. Perry, 610 So. 2d 746, 755 (La. 1992) (using that state's privacy provision to prohibit the state from administering psychotropic drugs to a death row prisoner for purposes of rendering him sufficiently competent to be executed). Reasoning that the Louisiana Constitution can be interpreted so as to expand the floor of fundamental rights, the court concluded that the state's privacy provisions included the "right to decide whether to obtain or reject medical treatment." Id. at 757.

The court also cites several other states that have subscribed to a fundamental right to choose one's own treatment program; a right that can only be infringed if the state can show that its choice of a treatment program is "narrowly tailored" to the government's ends. See Mitchell v. Fleming, 741 P.2d 674, 683 (Ariz. 1987) (holding that a patient's right to refuse treatment overrides the state's interest when death is inevitable); Bouvia v. Superior Ct., 179 Cal. App. 3d 1127, 1138 (Ct. App. 1986) (stating that a patient has the right to refuse any medical treatment, even if the treatment would save her life); Foody v. Manchester Memorial Hosp., 482 A.2d 713, 718 (Conn. Super. Ct. 1984) (stating that "state's interest in preserving life weakens and individual's right of privacy grows as the degree of bodily invasions necessary for treatment increases and the prognosis dims"); Brophy v. New England Sinai Hosp., Inc., 497 N.E.2d 626, 634 (Mass. 1986) (listing the criteria for when a state may override a patient's right to refuse medical treatment); In re Quinlan, 355 A.2d 647, 664 (N.J.), cert. denied, 429 U.S. 922 (1976) (stating that an individual may refuse medical treatment when the "prognosis is extremely poor" and "bodily invasion is very great"); see also supra note 313 . The Louisiana privacy provision states that "[e]very person shall be secure in his person, property, communications, houses, papers, and effects against unreasonable searches, seizures, or invasions of privacy." LA. CONST. art. I, \$5.

${ }^{319}$ See Town of Ennis v. Stewart, 807 P.2d 179, 182 (Mont. 1991) (holding that the privacy rights of its citizens under the Montana Constitution were more substantial than the rights guaranteed by the U.S. Constitution). The Montana privacy provision provides that "the right of individual privacy is essential to the well-being of a free society and shall not be infringed without the showing of a compelling state interest." MONT. CONST. art. II, § 10.

${ }^{320}$ See State v. Austin, 409 S.E.2d 811, 815 (S.C. Ct. App. 1991) (interpreting the South Carolina search and seizure provision more liberally than the federal analog). The South Carolina search and seizure provision establishes that "the right of the people to be secure in their persons, houses, papers, and effects against unreasonable searches and seizures and unreasonable invasions of privacy shall not be violated." S.C. CONST. art. I, § 10.

${ }^{321}$ See State v. Gunwall, 720 P.2d 808, 814-16 (Wash. 1986) (interpreting the Washington search and seizure provision more liberally than its federal analog). The Washington search and seizure provision establishes that "[n]o person shall be disturbed in his private affairs, or his home invaded, without authority of law." WASH. CONST. art. I, § 7. 
privacy provisions to advance substantive liberty interests beyond the federal analog. While none of the cases cited have involved the doctrine of "unconstitutional conditions," each has expressed, either explicitly or implicitly, a commitment to providing greater protection to fundamental liberty interests than that provided by the current Supreme Court. Therefore, each presents the opportunity to ground a right to community-based treatment for the mentally ill in their respective state constitutions. ${ }^{322}$

\section{Specific Constitutional Provisions for the Mentally IIl and the Custody Rationale}

A third strategy for advancing the claim that the mentally ill have a constitutional right to community-based treatment services could be grounded in the substantive due process doctrine of "custody." As developed in DeShaney v. Winnebago County Social Services Department, ${ }^{328}$ state "custody" over an individual triggers an affirmative obligation to ensure certain basic rights. ${ }^{324}$ As applied, the doctrine will be shown to be most effective in those states where the needs of the mentally ill have been recognized in particular state constitutional provisions. Moreover, the doctrine will be shown to include as a basic right, the right to have community-treatment programs developed.

In DeShaney, the petitioner (Joshua Deshaney) was a young child beaten into a coma by his chronically abusive father. Several reports of beatings had originally convinced the Department of Social Services ("DSS") of Winnebago County to "obtain[] an order from a Wisconsin juvenile court, placing Joshua in the temporary custody of the hospital. ${ }^{\text {325 }}$ But after being hospitalized for three days, Joshua was released from the custody of the court. A DSS caseworker did periodically check up on Joshua's condition, but despite observing evidence of child abuse; the caseworker took no

${ }^{322}$ As for Illinois, while one commentator believes the drafters of Article I, § 12 had intended the privacy provision to extend protection beyond the search and seizure context, see Cope, supra note 313, at 715, no case has interpreted it as such. See Sullivan v. Midlothian Park Dist., 281 N.E.2d 659, 662 (Ill. 1972) (noting that $§ 12$ is just a remedial provision expressing a philosophy of the state). Section 12 provides that " $[$ e]very person shall find a certain remedy in the laws for all injuries and wrongs which he receives to his person, privacy, property or reputation. He shall obtain justice by law, freely, completely, and promptly." ILL. CONST. art. I, $\S 12$.

s2s 489 U.S. 189 (1989).

${ }^{324}$ See id. at 199-200 (Brennan, J., dissenting).

${ }^{325}$ Id. at 192. 
action. After the incident in question, Joshua and his mother brought suit against DSS. They claimed that the state had "deprived Joshua of his liberty interest in 'free[dom] from .... unjustified intrusions on personal security,' by failing to provide him with adequate protection against his father's violence. ${ }^{326}$

Holding for DSS, the Court reasoned that ${ }^{\text {"[ }}$ w] hile the State may have been aware of the dangers that Joshua faced . . . , it played no part in their creation, nor did it do anything to render him any more vulnerable to them." ${ }^{\text {327 }}$ That the "State once took temporary custody of Joshua," did not render it "the permanent guarantor of [Joshua's] safety. ${ }^{\text {"28 }}$ Had a "special relationship" existed between the state and Joshua such that the state had assumed the role of protector, but failed to protect, then the state could have been held liable. ${ }^{329}$ Such a "special relationship" would have existed had Joshua been technically within the "custody" of the state. But limiting its conception of "custody" to instances of institutionalization and incarceration, the Court refused to extend it to Joshua's situation. ${ }^{330}$

Referring to the mental health context, the DeShaney Court did reaffirm the Youngberg $v$. Romeo ${ }^{331}$ rule that the institutionalized are entitled to a minimal level of training and treatment. ${ }^{332}$ But at no point did the Court, nor has the Court or the lower courts ${ }^{333}$ extended this "affirmative right" to those who are no longer, or have never been, institutionalized. As the dissent in DeShaney noted, "[b]ecause of the Court's initial fixation on the general principle that the Constitution does not establish positive rights, it is unable to appreciate our recognition ... that this principle does not hold true in all circumstances. ${ }^{\text {} 384}$

${ }^{326} \mathrm{Id}$. at 195 (quoting Ingraham v. Wright, 430 U.S. 651,673 (1977)).

327 Id. at 201.

${ }^{328} \mathrm{Id}$.

${ }^{329}$ See id. at 197.

${ }^{390}$ See id. at 198-201.

s31 457 U.S. 307 (1982); see also supra notes 164-72.

332 See DeShaney, 489 U.S. at 199-200.

${ }^{333}$ See, e.g., Philadelphia Police \& Fire Ass'n v. Philadelphia, 874 F.2d 156, 166-68 (3d Cir. 1989) (holding that Pennsylvania's withdrawal of assistance to developmentally disabled individuals living at home did not violate the substantive due process rights of the plaintiff class despite claims that such a withdrawal would inevitably lead to the deterioration of the plaintiff and subsequent committal in an institution). The court reasoned that under DeShaney no "special relationship" existed between the plaintiff class and the state to justify requiring the state to provide a certain minimal level of aid. See id. at 168.

${ }^{334}$ DeShaney, 489 U.S. at 205 (Brennan, J., dissenting). 
For Joshua, the illogic of DeShaney has been brutally self-evident. Similarly for the deinstitutionalized, the release into the streets without effective transitional assistance has meant personal deterioration at the micro-level, and an escalation of homelessness at the macro-level. ${ }^{335}$ Some states have acknowledged their responsibility to the deinstitutionalized mentally ill, passing statutes that reflect this concern. ${ }^{336}$ But most states have not provided the funding necessary to make transitional assistance a reality. In a very real sense, then, the deinstitutionalized are still dependent on the state.

For individuals who have never before been committed to institutions, but because of their illnesses are brought into the civil commitment process, "custody" begins immediately. In all fifty states, individuals alleged to be mentally ill and in need of treatment can be detained in an institutional setting. Depending on the state, these evaluative and treatment detentions can last anywhere from three days to thirty days, even before any final decision is made on the individual's commitment status. ${ }^{337}$ Whether these individuals

${ }^{335}$ See TORREY, supra note 17 , at 14-16.

${ }^{336}$ See, e.g., MONT. CODE ANN. § 53-21-185 (1991) (noting that the state's mental health department has "an affirmative duty to provide adequate transitional treatment and care for all patients released after a period of involuntary confinement").

${ }^{337}$ See ALA. CODE $§ 22-52-8$ (1990 \& Supp. 1993) (30 days); ALASKa STAT. $\S \S 47.30 .710$ to .725 (1990) (7 days); ARIZ. REV. STAT. ANN. § 36-535(B) (1993) (6 days); ARK. CODE ANN. $\$ 20-47-205$ (b) (Michie 1991) (12 days); CAL. WELF. \& INST. CODE $\$ \S 5206,5250$ (West 1984 \& Supp. 1993) (20 days); Colo. REV. STAT. $\$ \S ~ 27-10-$ 105(1)(a), -107(6) (1989) (15 days); CoNN. GEN. STAT. ANN. \$ 17a-502 (West 1992) (30 days); DEL. CODE ANN. tit. 16, $\S \S 5005(2), 5008$ (1) (Supp. 1992) (15 days, at least); FlA. STAT. ANN. $\S \S 394.463(2)(c), 394.467(3)($ a) (West 1993) (8 days); GA. CoDE ANN. $\S \S 37-3-64$ (a), 37-3-81(a) (1982 \& Supp. 1993) (19 days); HAW. REv. STAT. \$§ 334-59, 334-60.5(b), (g) (1985 \& Supp. 1992) (10 days, at least); IDAHO CODE $\$ \S 66-326(\mathrm{~d}), 66-$ 329(f) (1989 \& Supp. 1993) (7 days); ILL. ANN. STAT. ch. 405, para. 5/3-704(a), -706 (Smith-Hurd 1993) (8 days); IND. CoDE ANN. \$§ 12-26-4-1 to -5-11 (West Supp. 1992) (15 days); IOWA CODE ANN. § 229.11 (West 1985 \& Supp. 1993) (5 days); KAN. STAT. ANN. \$§ 59-2912, -2914(a)(1) (1983 \& Supp. 1992) (14 days); KY. REV. STAT. ANN. $\S 202 A .071$ (2) (Michie/Bobbs-Merrill 1991) (21 days); LA. REV. STAT. ANN. $\S \S 28: 53(A)(1), 28: 54(\mathrm{C})$ (West 1989) (15-18 days); ME. REV. STAT. ANN. tit. 34-B, § 3864(2), (5) (West 1988) (10 days); MD. CODE ANN., HEALTH-GEN. § 10-632(b) (Supp. 1992) (14 days); MASS. ANN. LAwS ch. 123, §§ 8B(c), 12(a), (d) (Law Co-op. 1989 \& Supp. 1993) (24 days); MICH CoMP. LAWS ANN. $\$ \S 330.1430,-.1452$ (West 1992) (11 days); MINN. STAT. ANN. \$§ 253B.05 subd. 3, 253B.08 subd. 1 (West 1982 \& Supp. 1993) (24 days); MISs. CODE ANN. \$§ 41-21-67(4), -71 (1993) (7 days); Mo. REV. STAT. §§ 632.305(2), 632.335(1) (1988) (11 days); MONT. CoDE ANN. §§ 53-21122(2)(b)(ii)(C), 53-21-124 (1991) (8 days); NEB. REv. STAT. \$§ 83-1023, -1026, -1036 (1987) (11 days); NEV. REV. STAT. ANN. \$§ 433A.150, 433A.220(1) (Michie 1991) (14 days); N.H. REv. STAT. ANN. \$§ 135-C:29, 30, 32 (1990) (10 days, at least); N.J. STAT. ANN. \$§ 30:4-27.10, -27.12 (West Supp. 1993) (20 days); N.M. STAT. ANN. § 43-1-10 
are seen as merely within the "clutches" of the state, or fully within state "custody," an affirmative right to at least some level of minimally adequate treatment should be formally recognized. What are the contours of that right and how can it translate into a right to community-based services are questions that remain to be answered. In a recent article in the Yale Law Journal, Professor Susan Stefan offers some answers. ${ }^{338}$

Stefan provides a solid foundation for building a right to community-based services. She does so by interpreting the right to minimal training established in the Youngberg case as requiring more than mere judicial deference to the judgment of mental health professionals. ${ }^{339}$ In characterizing what is minimally required when the mentally ill are within the state's "custody," Stefan argues that courts should not be allowed to abdicate their responsibilities as guardians of freedom once the professional judgment standard

(Michie 1993) (8 days); N.Y. MENTAL HYG. LAW § 9.39(a) (McKinney 1988) (15 days); N.C. GEN. STAT. §§ 122C-263, -268 (1989 \& Supp. 1992) (10 days); N.D. CENT. CODE $\S \S 25-03.1-11, .1-17, .1-26, .1-29$ (1989 \& Supp. 1993) (21 days); OHIO REV. CODE ANN. $\S \S 5122.10,5122.14$ (Anderson 1993) (12 days); OKLA. STAT. ANN. tit. 43A, § 5-211 (West 1990 \& Supp. 1993) (28 days); OR. REV. STAT. ANN. § 426.095(2) (Supp. 1992) (8 days); PA. STAT. ANN. tit. 50, \$§ 7302(d)(2), 7303(f) (Supp. 1993) (25 days); R.I. GEN. LAWS $\$ \S 40.1-5-7(6), 40.1-5-8(4)$ (1990) (31 days); S.C. CODE ANN. § 44-17-410(3) (Law Co-op. 1985 \& Supp. 1992) (15 days); S.D. CoDIFIED LAwS ANN. \$§ 27A-10-5, 27A-10-7 (1992) (6 days); TENN. CODE ANN. \$§ 33-3-501, 33-3-606, 33-6-103(v) (1984 \& Supp. 1993) (15-30 days); TEX. HEALTH \& SAFETY CODE ANN. $§ \S 574.005,574.013$, 574.026 -.027 (West 1992) (30 days); UTAH CODE ANN. \$§ 62A-12-232(3), 62A-12234(3), (8) (1989 \& Supp. 1993) (18 days); VT. STAT. ANN. tit. 18, §§ 7508(d), 7510(a), (b), 7615 (1987) (17-27 days); VA. CODE ANN. § 37.1-67.1 (1990 \& Supp. 1993) (4 days); WASH. REV. CODE ANN. $§ \S 71.05 .180,71.05 .200$ (1) (West 1992) (20 days); W. VA. CODE § 27-5-2 (1992) (30 days); WIS. STAT. ANN. § 51.20(7)(c) (West 1987 \& Supp. 1993) (14 days); WYO. STAT. § 25-10-109 (1990) (16 days).

Compare this to the time frame envisioned by the National Task Force on Guidelines for Involuntary Civil Commitment:

Established law requires that an evidentiary hearing be held within a reasonable period of time after a respondent is admitted and involuntarily detained in a mental health facility or a petition for involuntary civil commitment is filed.

(a) A hearing should be held as soon as possible, but no more than three court days after a respondent has been taken into custody or a petition for involuntary civil commitment has been filed and is pending with the court.

INSTTIUTE ON MENTAL DisabitTry AND THE LAW, NATIONAL CTR. FOR STATE CourTs, Guidelines fOR INVOLUNTARY CIVIL COMMTTMENT 60 (1986) (Guideline F2(a)) (emphasis added).

${ }^{338}$ See Susan Stefan, Leaving Civil Rights to the 'Experts': From Deference to Abdication Under the Professional Judgment Standard, 102 YALE L.J. 639 (1992).

${ }^{339}$ For a discussion of Youngberg, see supra text accompanying notes 164-72. 
is invoked. ${ }^{340}$ Instead, Youngberg should be interpreted to establish a right to treatment that would ensure that those within the state's custody are treated so that their "release from confinement could be expedited." 341 Although Stefan defines "custody" as institutionalization, her argument could and should be extended to other forms . of "custody." Thus, for the deinstitutionalized, community-based treatment would be justified as necessary to prevent re-institutionalization. And similarly for the "potentially" institutionalized, community-based services would be the natural antidote for civil commitment.

Granted, this approach is not only an extension of the DeShaneyYoungberg logic, but arguably also of Stefan's. ${ }^{342}$ For this reason, it is highly unlikely that the Supreme Court would support it. Since the argument requires that the mentally ill have a constitutionally based, affirmative claim to treatment in the community (as a condition of ensuring minimal basic rights under Youngberg), an effective location for making such a claim would be in state constitutions that have expressed a particular interest in the rights of the mentally ill.

In Texas, for example, a court of civil appeals used Article I, Section 15(a) of its state constitution to make the same type of argument that Professor Stefan has made. ${ }^{343}$ Article I, Section 15(a) provides that " $[n]$ o person shall be committed as a person of unsound mind except on competent medical or psychiatric testimony. The legislature may enact all laws necessary to provide for a method of appeal from judgments rendered in such cases. ${ }^{\text {n34 }}$ As the court in Moss construed it, Section 15(a) requires that "[a] person suspected of mental illness not be deprived of liberty on the basis of medical expert opinion alone. ${ }^{\text {345 }}$ Instead, because of the extensive liberty interests involved, both medical and legal determinations must be made. In accepting the plaintiff's claim that there were insufficient factual grounds upon which to

${ }^{340}$ See Stefan, supra note 338 , at $644-45$.

${ }^{341} \mathrm{Id}$. at 692 .

${ }^{342}$ See id. at 694 n.268 (limiting her argument, in light of DeShaney, to those already in the state's custody).

s4s See Moss v. State, 539 S.W.2d 936, 949-50 (Tex. Civ. App. 1976); see also Holliman v. State, 762 S.W.2d 656, 658 (Tex. Ct. App. 1988) (citing Moss for the proposition that expert medical opinions are not sufficient to deprive an individual of liberty).

${ }^{344}$ TEX. CONST. art. I, § 15(a).

${ }^{345}$ Moss, 539 S.W.2d at 949. 
base her civil commitment, the court noted its general distrust of the ability of psychiatrists to make predictive decisions about human behavior. ${ }^{346}$

Moss lays an essential foundation for going beyond what Youngberg has been traditionally interpreted as requiring. If Stefan is correct, and Youngberg should be interpreted as requiring treatment necessary to ensure an expedited release from confinement, then Moss provides the necessary tools for advancing the "custody" argument outlined above. Moreover, like Texas, the states of Arkansas, ${ }^{347}$ Idaho, ${ }^{348}$ Mississippi, ${ }^{349}$ Ohio, ${ }^{350}$ Oklahoma, ${ }^{351}$ and Washington ${ }^{352}$ also have constitutional provisions that refer to the mentally ill. Unlike Texas, however, these six all phrase the rights involved in affirmative terms, rendering these jurisdictions even more likely to support a state constitutional right to community-based treatment. ${ }^{353}$

${ }^{346}$ See id. at $950-51$.

347 See ARK. CONST. art. XIX, § 19 (stating that the General Assembly must "provide by law for the support of institutions ... [and] for the treatment of the insane").

${ }^{348}$ See IDAHO. CONST. art. X, $\$ 1$ (providing that "institutions . . . for the benefit of the insane ... shall be established and supported by the state").

${ }^{49}$ See MISS. CONST. art. IV, $\$ 86$ (stating that "it shall be the duty of the legislature to provide by law for the treatment and care of the insane"); id. art. XIV, $\$ 262$ (allowing provision of "asylums for those persons who, by reason of age, infirmity, or misfortune, may have claims upon the sympathy and aid of society").

${ }^{350} \mathrm{See}$ OHIO. CONST. art. VII, $\S 1$ (providing that "[i]nstitutions for the benefit of the insane, blind, and deaf and dumb, shall always be fostered and supported by the state; and be subject to such regulations as may be proscribed by the general assembly"). In one case interpreting this constitutional provision, the Ohio Supreme Court ruled 4-3 that the juvenile court lacked the authority to order the department of mental health to pay for the cost of caring for children placed in private, nonpublic psychiatric hospitals. See In re Hamil, 431 N.E.2d 317, 318 (Ohio 1982). The court in Hamil essentially interpreted the state statute as providing a right to treatment in the least restrictive setting available. If a better alternative is not available, however, the plaintiff must remain in the more restrictive environment. See id. at 321.

${ }^{351}$ See OKLA. CONST. art. XXI, $\$ 1$ (mandating establishment and support of institutions for the insane).

${ }^{352}$ See WASH. CONST. art. XIII, $\S 1$ (mandating that institutions "for persons who are mentally ill or developmentally disabled ... shall be fostered and supported by the state").

${ }^{353}$ Affirmative rights can also be found in other state constitutional provisions, and can be used as a source of expansive rights protection, as well. See, e.g., California First Bank v. State, 801 P.2d 646, 658 (N.M. 1990) (holding that a cause of action exists for plaintiff to sue-as the representative of the estates of those killed by a drunk driver-the city, and noting that the due process clause of the New Mexico Constitution expressly guarantees the right "of seeking and obtaining safety"); Hodge v. Ginsberg, 303 S.E.2d 245, 247 (W. Va. 1983) (holding that the homeless are entitled to protective services under Article III, $\S 10$ of the state constitution, because 
Several other states are also fertile territories for advancing this argument. And though their constitutional provisions and state court decisions do not, like Texas's, self-evidently tie into the Youngberg-DeShaney "custody" approach, these states have interpreted their constitutional provisions to justify treating the mentally ill and mentally disabled as constitutionally protected classes. In fact, courts in Louisiana, ${ }^{354}$ Montana, ${ }^{355}$ and Michigan ${ }^{356}$ employ dicta evincing constitutionally based concerns for the provision of less restrictive residential alternatives.

the constitution is meant to guarantee the benefits of legislative enactments); see also N.Y. CONST., art. XVII, $\$ 1$ ("The aid, care and support of the needy are public concerns and shall be provided by the state and by such of its subdivisions, and in such manner and by such means, as the legislature may from time to time determine"); MONT. CoNsT., art. XII, § 3(3) ("The legislature may provide such economic assistance and social and rehabilitative services for those who, by reason of age, infirmities, or misfortune are determined by the legislature to be in need."); Butte Community Union v. Lewis, 712 P.2d 1309, 1311 (Mont. 1986) (applying heightened scrutiny to regulation that abridged welfare rights which the court found to be important but rejecting proposition that welfare is a fundamental right because Article XII, $\S 3(3)$ is not part of the Declaration of rights).

${ }^{354}$ See Clark v. Manuel, 463 So. 2d 1276, 1285 n.14 (La. 1985) (holding unconstitutional a discriminatory city zoning ordinance, and noting that Article $I, \S 3$ of the Louisiana Constitution, as well as statutory provisions passed to implement $\S 3$ rights, clearly evinced a concern for the promotion of less restrictive residential alternatives for the mentally retarded). Article I, $\S 3$ provides that "[n]o law shall arbitrarily, capriciously, or unreasonably discriminate against a person because of birth, age, sex, culture, physical condition, or political ideas or affiliations." LA. CONST. art. I, § 3 (emphasis added).

${ }_{355}$ See State v. District Ct., 609 P.2d 245, 247 (Mont. 1980) (quashing an injunction that had enjoined the opening of a group home for the developmentally disabled). The court interpreted Article XII, $\$ 3$ of the state constitution as establishing, among other things, the constitutional rights of the "developmentally disabled to live and develop within . . . community structure as a family unit, rather than be segregated in isolat[ion]." Id. at 247 (quoting State v. Missoula, 543 P.2d 173, 177-78 (Mont. 1975)).

${ }_{356}$ See City of Livonia v. Department of Social Servs., 378 N.W.2d 402, 416 (Mich. 1985) (holding that the wording of Article VIII, $\S 8$ of the state constitution was specifically revised to reflect the belief that the treatment of the mentally ill should not be restricted to institutionalization). Article VIII, $\$ 8$ expansively provides that "[i]nstitutions, programs and services for the care, treatment, education or rehabilitation of those inhabitants who are physically, mentally or otherwise seriously handicapped shall always be fostered and supported." MICH. CONST. art. VIII, § 8. 


\section{B. Equal Protection}

The Equal Protection Clause of the United States Constitution provides, in part, that "[n]o State shall ... deny to any person within its jurisdiction the equal protection of the laws. ${ }^{\text {n57 }}$ Under the traditional standard of equal protection review, a legislative classification will be sustained if there is a rational basis for distinguishing between the class to which the law is applicable and the class to which it is not. ${ }^{358}$ Because under such a standard the reasonableness of the classification is presumed, the party challenging it has the burden of establishing its invalidity. As has been the case with post-Lochner substantive due process review, this rationalbasis standard applies primarily to economic classifications and those dealing with general social welfare regulations. ${ }^{359}$

When classifications, however, tend to impinge upon a fundamental right or disadvantage a "suspect" class of individuals, the presumption of constitutionality that marks traditional, rationalbasis review is reversed. ${ }^{360}$ Instead, under strict-scrutiny review, the state must illustrate that its classification is the least restrictive means by which to further some compelling state interest. If the means employed are not the least restrictive, the classification will be deemed to be motivated by a bias towards the class affected, and the statute will be rendered unconstitutional.

As applied to civil commitment statutes, the least restrictive alternative doctrine should assist courts in unearthing legislative schemes that are "overinclusive," that unnecessarily and improperly institutionalize individuals who would be better treated in the community. ... The states' failure to develop and fund communitybased services would thus be seen by courts as reflecting the states' disdain for the individualized needs of the mentally ill. ${ }^{361}$ To

${ }^{357}$ U.S. CONST. amend. XIV, § 1.

${ }^{838}$ See Massachusetts Bd. of Retirement v. Murgia, 427 U.S. 307, 312, 314 (1978) (subjecting to rational basis review a Massachusetts statute that requires uniformed police officers to retire at age 50 ).

${ }^{359}$ See New Orleans v. Dukes, 427 U.S. 297, 303 (1976).

${ }^{360}$ See Murgia, 427 U.S. at 312; see also TRIBE, supra note 200, at 1451-54.

${ }^{361}$ Cf. C. Edwin Baker, Outcome Equality or Equality of Respect: The Substantive Content of Equal Protection, 131 U. PA. L. REV. 933 (1983). Baker interprets the Equal Protection Clause as designed to ensure that the inherent worth of a category of citizens is not subordinated or denigrated. See id. at 959. Application of the Equal Protection Clause standard aids the Court in disclosing "subordinating and denigrating purposes." Id. at 974-76, 992. As John Hart Ely characterizes this process, the Equal Protection Clause "flush[es] out unconstitutional motivations." ELY, supra note 115, at 153; cf. TRIBE, supra note 200, at 1515 (developing an 
trigger strict judicial scrutiny, two approaches will be proposed. First, it will be argued that the mentally ill are a suspect class and any classifications affecting their interests should employ the least restrictive means appropriate. Second, it will also be argued that the mentally ill most "at risk" of being civilly committed are the poorest of a class of very poor individuals. Any classifications that restrict their ability to exercise a fundamental right should also be subjected to strict judicial scrutiny.

\section{Courts Characterizing the Mentally Ill as a Suspect Class}

Suspect classifications that trigger strict scrutiny review are not easy to characterize. In fact, the uncertainty of the Court's jurisprudence in this area has resulted in powerful criticisms being levelled against it, not the least of which has come from the Court's own membership. ${ }^{362}$ In San Antonio School District $v$. Rodriguez, ${ }^{363}$ however, the Court attempted to provide some guidance, listing as to the "traditional indic[es] of suspectness:" that a class be "saddled with such disabilities, or relegated to such a position of political powerlessness as to command extraordinary protection from the majoritarian political process. ${ }^{\text {364 }}$ Commentators, in turn, have focused on the "immutability of the classifying trait," "stigmatization," and membership in a "discrete and insular" minority to define the contours of a suspect class. ${ }^{365}$ But despite

"antisubjugation" principle for equal protection analysis, "which aims to break down legally created or legally reenforced systems of subordination that treat some people as second-class citizens").

${ }^{362}$ See Craig v. Boren, 429 U.S. 190, $211-12$ (1976) (Stevens, J., concurring) (arguing that the Court should not apply "one standard of review in some cases and a different standard in other cases"); see also Jeffrey H. Blattner, The Supreme Court's Intermediate Equal Protection Decisions: Five Imperfect Models of Constitutional Equality, 8 HASTINGS CONST. L.Q. 777, 779, 817 (1981) (noting that the Court's determination of who is truly "disadvantaged," depends on a particular social vision, or on a "theory of just and unjust disadvantaging"); John H. Ely, The Constitutionality of Reverse Racial Discrimination, 41 U. CHI. L. REV. 723, 734 (1974) (noting that the Court has provided no guidance on how to determine who should be characterized as a suspect class); Douglas R. Widin, Comment, Suspect Classifications: A Suspect Analysis, 87 DICK. L. REv. 407, 432 (1983) (noting that regardless of whether a black woman is irrelevantly classified on the basis of her sex, rather than race, it "does not change the character of the burden imposed or vitiate the equal protection violation").

${ }^{363} 411$ U.S. 1 (1973).

${ }^{364} I d$. at 28.

${ }^{365}$ ELY, supra note 115 , at $150-53$ (discussing the different perspectives that commentators bring to this issue). Ely argues that "prejudice against discrete and insular minorities" is the proper standard since it limits the Court's concern to those who, because of legislative prejudice or generalizations, have not been treated with 
attempts to make sense of the Court's "suspect classification" doctrine, there is still no coherent set of principles that guides us. ${ }^{366}$

What we do know, however, is that the current Supreme Court is unlikely to treat the mentally ill with the same level of judicial solicitude provided racial and ethnic groups. In City of Cleburne $v$. Cleburne Living Center, ${ }^{367}$ the Supreme Court grappled with the issue of whether a city ordinance that required the mentally retarded to obtain special use permits for group homes violated the Equal Protection Clause. In rendering its decision, however, the Court seemed less preoccupied with the particulars of the case, and more preoccupied with determining the threshold question of where to place the mentally disabled along the continuum of classifications. Downplaying the lengthy history of discriminatory treatment against the mentally disabled, the Court instead emphasized the number of political victories accorded the mentally disabled and the costs of extending suspect status to yet another class of individuals. ${ }^{368}$ After six pages of analysis, the Court concluded not only that the mentally disabled did not need the Court's help, but also that even if they did the Court was not interested in providing any. ${ }^{369}$ Although the Court subjected the classification of the mentally disabled to rational-basis review, the Court did what it almost never does when applying minimal level scrutiny; it invalidated the ordinance. ${ }^{370}$

In his partially concurring and dissenting opinion, Justice Marshall moved away from the majority's political participation analysis, arguing that given the "lengthy and tragic history' of segregation and discrimination" that has riddled the lives of the mentally disabled, any level of scrutiny lower than heightened would be inappropriate. ${ }^{371}$ Marshall reasoned further that "political

equal concern and respect and who have been effectively excluded from political participation. Id. at $150-70$.

366 See id. at 149; Note, The Constitutional Status of Sexual Orientation: Homosexuality as a Suspect Classification, 98 HARV. L. REV. 1285, 1297 (1985).

${ }^{367} 473$ U.S. 432 (1985).

${ }^{368}$ See id. at $440-46$.

${ }^{369}$ See id. at 446.

${ }^{370}$ See id. at 448 (invalidating the ordinance as applied and noting that the only explanation available for the classification was fear of, and prejudice towards, the mentally retarded); see also id. at 459-60 n.4 (Marshall, J., concurring in part and dissenting in part) (noting how infrequently legislation has been struck down under rational basis review).

${ }^{371} I d$. at 461 (Marshall, J., concurring in part, dissenting in part) (quoting 
powerlessness of a group and the immutability of its defining trait are relevant insofar as they point to a social and cultural isolation." ${ }^{372}$ Chronicling historical as well as current indices of isolation, Marshall concluded that from a social and cultural perspective the mentally disabled should, in fact, be characterized as a discrete and insular minority. ${ }^{373}$ Marshall did not win the interpretive battle, nor did he identify the indices of suspectness that has motivated the Court's multi-tiered review. Nevertheless, his conception of the mentally retarded as a group that has been subordinated throughout history, both socially and culturally, weaves together several strands of thought on what constitutes a suspect class. ${ }^{374}$

If, under Marshall's analysis, classifications affecting the mentally retarded should be viewed with suspicion, then so should classifications affecting the mentally ill. Consider the following two depictions:

[P]eople who are involuntarily committed tend to be social outcasts even before they walk through the hospital door. Overwhelmingly, they are poor and unemployed or working in poorly paid jobs. They rarely have more than a high school education, and most lack [the] skills or experiences for anything but the lowest-paying jobs. ${ }^{375}$

The care of the severely mentally ill in twentieth century America has been a public disgrace. Over fifty years of warehousing patients in inhumane state hospitals has been followed by almost forty years of dumping them into bleak boarding homes or onto the streets. It has been an era of remarkably poor planning and

University of Cal. Regents v. Bakke, 438 U.S. 265, 303 (1978)).

${ }^{372} I d$. at 472 n. 24 .

${ }^{373}$ See id. at 465-73 \& n.24; see also Trautz v. Weisman, 819 F. Supp. 282, 291-95 (S.D.N.Y. 1993) (describing the developmentally disabled as a discrete and insular minority for purposes of interpreting 42 U.S.C. \$ 1985(3)).

${ }^{374}$ See, e.g., ELY, supra note 115, at 160 (noting that while political access is important, social access is an equally relevant consideration in understanding what constitutes a discrete and insular minority); TRIBE, supra note 200, at 1516 ("Mediated by the antisubjugation principle, the equal protection clause asks whether the particular conditions complained of, examined in their social and historical context, are a manifestation of a legacy of official oppression."); Baker, supra note 361, at 976 (highlighting his "equality of respect model's no subordinating purpose principle").

${ }^{375}$ LA FOND \& DURHAM, supra note 11, at 140-41; see also Rapson, supra note 284, at 215 (describing the mentally ill as "economically, politically, and legally vulnerable"); News E' Notes: Mental Illness Remains a Source of Stigma, National Survey of Public Attitudes Finds, 41 HOSP. \& COMMUNITY PSYCHIATRY 819, 819 (1990) (65\% of those polled "believe that a great deal of stigma is attached to mental illness"). 
inept policy formulation. Professional self-interest has been confused with altruism, official inaction with benevolence, ideology with science, and ignorance with omniscience. ${ }^{\mathbf{3 7 6}}$

Feared, stereotyped, and poorly treated, the mentally ill would even appear to meet the Cleburne majority's "political powerlessness" criterion for suspectness. ${ }^{377}$

Given the overwhelming historical evidence of social, cultural, and political isolation and subordination, courts should subject all laws affecting the mentally ill to strict judicial scrutiny. With respect to the civil commitment process, application of the "least restrictive alternative" prong of strict scrutiny analysis would require states to establish and finance effective community-based alternatives if they wanted their legislative schemes to survive. Because not financing such alternatives would essentially render all individuals with mental illnesses civilly committable, those who could be more effectively treated in the community would be unnecessarily deprived of their liberty and of the opportunity to receive appropriate care. Failing to finance and develop community-based alterna-

${ }^{376}$ TORREY, supra note 17 , at 199.

${ }^{377}$ See Bach, supra note 17, at 1160 (noting that "[t]he mentally ill lack the constituency necessary to effect majoritarian reform"); see also Rapson, supra note 284, at 216 ("[T]heir economic powerlessness is paralleled by their lack of political influence. Because they are unlikely to organize around issues that affect them or take other actions that would generate political influence, the mentally ill are not a weighty constituency."); Note, Mental Illness: A Suspect Classification, 83 YALE L.J. 1237, 1259 (1974) (noting that classifications affecting the mentally ill should be accorded strict judicial scrutiny because the mentally ill are often denied the right to vote, are in the minority, are consigned to insularity because of people's aversion to personal contact with them, and are typically victimized by ill-fitting legislative classifications). But see Developments in the Law: Civil Commitment of the Mentally IIl, 87 HARV. L. REV. 1190, 1229-30 n.153 (1974) (noting that while "mental illness involves some of the indicia normally associated with suspect classification," mental illness is not an "immutable personal characteristic, determined at birth, which bears little relation to the individual's ability to perform many tasks").

Moreover, as compared to the mentally disabled, the mentally ill have historically been at a political disadvantage. Not only do the mentally disabled lobby more aggressively and effectively than the mentally ill, but those who do the lobbying are also more understanding of the needs of those they lobby for. See BRAREL ET AL., supra note 30, at 337-38, 616-17 \& n.121, 619; Jeffrey Wilson \& Anthony Kouzi, Quality of the Residential Environment in Board-and-Care Homes for Mentally and Developmentally Disabled Persons, 41 HOSP. \& COMMUNITY PSYCHITTRY 314, 317-18 (1990) (noting how relatives of the mentally disabled often play a large role in the lobbying efforts for the mentally disabled while only "concerned citizens" and professional groups tend to rally for the mentally ill, and noting that, at least in the area of community-based, residential treatment, the mentally disabled are able to get significantly more funding per patient than the mentally ill are). 
tives, while still maintaining the coercive authority to commit the mentally ill, would, in other words, belittle the individualized needs of the mentally ill. This lack of respect and concern is precisely what the Equal Protection Clause is designed to eliminate. ${ }^{378}$

With the U.S. Supreme Court intimating that classifications affecting the mentally ill will not enjoy heightened scrutiny, ${ }^{379}$ resort to state constitutionalism becomes even more of a necessity. Although no state court has yet officially characterized the mentally ill as a suspect class, only one has ever said they are not. ${ }^{380}$ Moreover, some states have even voluntarily expressed an appreciation for the discreteness and insularity of the mentally ill. In Estate of Roulet, ${ }^{381}$ for example, the California Supreme Court noted that " $[t]$ he former mental patient is likely to be treated with distrust and even loathing; he may be socially ostracized and victimized by employment and educational discrimination. ... [T]he individual's hospitalization and posthospitalization experience may cause him to lose self-confidence and self-esteem. ${ }^{\text {382 }}$ Similarly, the New Hampshire Supreme Court noted that "an enlightened view of mental illness 'does not yet prevail," and proceeded to quote the California court. ${ }^{383}$ As for the remaining states that have not even considered the discreteness and insularity of the mentally ill, at least fourteen of them have historically interpreted their equal protection provisions more liberally than the federal analog, and would likely be amenable to characterizing the mentally ill as a "suspect class." ${ }^{384}$

${ }^{378}$ While it may certainly cost more in the short-run to make the fit better, it is warranted. See ELY, supra note 115, at 169 (to make a "more individualized test of qualification[,] . . . [t] he unusual dangers of distortion in situations of self-aggrandizing generalization seem also to demand that we bear the increased costs of more individualized justice").

${ }^{379}$ Although Cleburne's characterization of the mentally disabled would alone suffice to draw this conclusion, the Court also explicitly makes reference to the mentally ill. See Cleburme, 473 U.S. at $445-46$ (noting that since it is not about to extend suspect or quasi-suspect status to the mentally ill, it certainly is not about to extend it to the mentally disabled).

${ }^{380}$ See Williams v. Secretary of Executive Office, 609 N.E.2d 447, 456 (1993).

381590 P.2d 1 (Cal. 1979).

${ }^{882}$ Id. at 7.

sss Proctor v. Butler, 380 A.2d 673, 676 (N.H. 1977) (quoting People v. Burnick, 535 P.2d 353, 362 (Cal. 1975)), overruled by In re Sanborn, 545 A.2d 726 (N.H. 1988).

${ }^{384}$ The 14 states are: Alaska, see Herrick's Aero-Auto Repair v. State Dep't of Transp., 754 P.2d 1111, 1114 (Alaska 1988); Patrick v. Lynden Trans., Inc., 765 P.2d 1375, 1377 (Alaska 1988); California, see Serrano v. Priest, 557 P.2d 929, 950 (Cal. 1977); Connecticut, see Doe v. Maher, 515 A.2d 134, 160-61 (Conn. Super. Ct. 1986); Hawaii, see State v. Kaluna, 520 P.2d 51, 58-59 (Haw. 1974); Michigan, see Doe v. Director of Dep't. of Social Servs., 468 N.W.2d 862, 870-75 (Mich. Ct. App. 1991), 


\section{Courts Liberally Gonstruing Wealth Classifications}

Even if a court were reluctant to characterize the mentally ill as a suspect class, there still remain other aspects of the civil commitment process that merit strict scrutiny. Most notably is the degree of poverty experienced by those institutionalized, the deinstitutionalized, and those "at risk" of being institutionalized for the first time. For each of these groups, the correlation between poverty and mental illness is beyond doubt; all that has remained at issue is the causal relationship between the two. ${ }^{385}$ As Judge Bazelon noted

rev'd on other grounds, 487 N.W.2d 166 (Mich. 1992); Montana, see Pfost v. State, 713 P.2d 495, 500 (Mont. 1985), overruled on other grounds, 776 P.2d 488 (Mont. 1989); New Jersey, see Right to Choose v. Byrne, 450 A.2d 925, 936-37 (N.J. 1982); New Mexico, see Chapman v. Luna, 701 P.2d 367, 368 (N.M. 1985); Oregon, see Cooper v. Oregon Sch. Activities Ass'n, 629 P.2d 386, 391 (Or. Ct. App. 1981); South Dakota, see Behrns v. Burke, 229 N.W.2d 86, 88-89 (S.D. 1985); Texas, see In re McLean, 725 S.W.2d 696, 698 (Tex. 1987); Utah, see Blue Cross \& Blue Shield v. State, 779 P.2d 634, 637 (Utah 1989); West Virginia, see Robertson v. Goldman, 369 S.E.2d 888, 892 (W. Va. 1988); Wyoming, see Washakie v. County Sch. Dist. No. 1, 606 P.2d 310, 332 (Wyo. 1980).

Very few states actually have "equality" provisions that mirror the federal Equal Protection Clause. Instead, most states have interpreted a right to equal protection under the law pursuant to their state due process provisions. The logic behind this approach can be traced back to the Supreme Court's decision in Bolling v. Sharpe, 347 U.S. 497 (1954), where the Court applied the Fourteenth Amendment's requirements of equal protection to the District of Columbia's public schools through the Fifth Amendment's due process provision. See id. at 499.

Only eight states have "equality" provisions as we commonly understand them. See Sidney Z. Karasik, Equal Protection of the Law Under the Federal and Illinois Constitutions: A Contrast in Unequal Treatment, 30 DEPAUL L. REV. 263, 270 n.33 (1980). As interpreted by most state courts, however, these provisions differ fundamentally from their federal analog. As one commentator put it, "whereas the equal protection clause was designed to safeguard minorities from majoritarian excesses, the state equality guarantees ... largely served to protect the majority against legislative creation of special privileges or exemptions that destroy equality under the law." Tarr, supra note 206 , at 860.

${ }^{385}$ See Bruce P. Dohrenwend, Socioeconomic Status and Psychiatric Disorders: The CausationSelection Issue, 255 SCIENCE 946, 951 (1992) (noting that since 1855 the relationship between poverty and mental illness has proven to be "remarkably consistent," and concluding that "social causation theory," by which poverty causes mental illness, was a stronger factor than the "social selection theory," which holds that the mentally ill are genetically predisposed to mental illness and become poor as a consequence); Virginia A. Hiday, Civil Commitment: A Review of Empirical Research, 6 BEHAV. SCI. \& L. 15, 18 (1988) (noting that the "sociodemographic characteristics of civil commitment candidates are so well established that articles addressing this subject are noticeably absent in the post reform period," and that these candidates tend to be poor or indigent); see also Ludwig, supra note 16, at 109293 (pointing out that $85 \%$ to $90 \%$ of long-term state hospital patients have been indigent, have exhausted or have been stripped of most of their assets by the time they were committed); Arthur J. Lurigio \& Dan A. Lewis, Worlds that Fail: A 
in describing the plight of Ms. Lake,

[t]his appellant, as appears from the record, would not be confined in Saint Elizabeths if her family were able to care for her or pay for the care she needs. Though she cannot be given such care as only the wealthy can afford, an earnest effort should be made to review and exhaust available resources of the community in order to provide care reasonably suited to her needs. ${ }^{386}$

While mental illness certainly does affect the middle and upper classes, these individuals (unlike Ms. Lake) often have the family support and the financial support to make use of private, noninstitutionalized alternatives. Those who are committed, as well as candidates for civil commitment, tend to be, however, the poorest of the poor, "overwhelmingly from the bottom of the social structure." "The more privileged have their own alternatives: resources to provide care at home or in a private hospital, [and] education and resources to seek and obtain help before symptoms become truly dangerous. ${ }^{387}$

But is indigency a suspect class? Do legislative schemes that disproportionately impact upon the poor warrant strict judicial scrutiny? Beginning with the Warren Court and continuing into the early years of the Burger Court, several decisions conveyed the idea that indigency was, in fact, a suspect classification. In Griffin $v$. Illinois, ${ }^{388}$ for example, the Supreme Court noted that "[i]n criminal trials a State can no more discriminate on account of poverty than on account of religion, race, or color. ${ }^{389}$ And in Tate $v$. Short, ${ }^{390}$ the High Court held that to incarcerate an indigent civil offender simply because he could not afford to pay his fines was a denial of equal treatment. ${ }^{391}$

Longitudinal Study of Urban Mental Patients, $45 \mathrm{~J}$. Soc. IsSUEs 79, 81 (1989) (finding that a sample of state mental patients in Chicago were "predominantly poor, unemployed, and on welfare"); Perlin, supra note 11, at 102 (noting that "persons of lower socioeconomic status are more likely than those of middle and upper status to develop symptoms of distress in response to problematic life experiences").

${ }^{386}$ Lake v. Cameron, 364 F.2d 657, 660 (D.C. Cir. 1966).

${ }^{587}$ Hiday, supra note 385 , at 18 (noting that the few middle class candidates tend to be more physically violent and thus are the ones most appropriately suited for civil commitment).

${ }^{388} 351$ U.S. 12 (1956).

${ }^{889} \mathrm{Id}$. at 17 (holding that Illinois must provide indigent criminal appellants with a free transcript of trial proceedings because a transcript was required before Illinois courts would grant appellate review).

${ }^{390} 401$ U.S. 395 (1971).

${ }^{391}$ See id. at 398-99. 
These cases and others ${ }^{392}$ reflected the belief that while disparities in wealth were inevitable, one's ability to make use of the political and judicial processes should not be affected by such disparities. As time went on, however, the Burger Court "abandoned the ardent rhetoric of equal justice for the poor, rhetoric which promised more than even the Warren Court had delivered, and far more than the Burger Court was prepared to deliver in the name of equal protection of the laws. ${ }^{393}$ As a result, the Court began to subject classifications affecting the poor to rationality review, ensuring that the most needy would not find redress in the federal courts. ${ }^{394}$ In fact, the Court in San Antonio Independent School District $v$. Rodriguez ${ }^{395}$ made absolutely clear that wealth classifications alone would not be subjected to strict judicial scrutiny. ${ }^{396}$ Classifications, however, that impermissibly interfered with the exercise of a "fundamental right" would still be subjected to strict scrutiny review, even if the classification itself did not involve a suspect class. ${ }^{397}$ Although the Rodriguez Court narrowed its

${ }^{392}$ See, e.g., Harper v. Virginia Bd. of Elections, 383 U.S. 663, 666 (1966) (holding Virginia's poll tax unconstitutional); Douglas v. California, 372 U.S. 353, 358 (1963) (holding the state's refusal to provide indigent appellants counsel for their first appeal an equal protection violation).

${ }^{393}$ TRIBE, supra note 200, at 1626; see also Stephen Loffredo, Poverty, Democracy, and Constitutional Law, 141 U. PA. L. REv. 1277, 1306 (1993) (noting that the Burger Court began to "mechanically attach the usual presumption of constitutionality to classifications that affect the poor, without inquiring into the democratic legitimacy of the underlying process").

${ }^{394}$ See, e.g., Ortwein v. Schwab, 410 U.S. 656, 660 (1973) (holding constitutional, after applying rationality review, a $\$ 25$ filing fee to appeal state welfare agency decisions reducing benefits); San Antonio Indep. Sch. Dist. v. Rodriguez, 411 U.S. 1, 55 (1973) (upholding Texas's school financing scheme despite wide funding disparities between property-rich and property-poor school districts).

${ }^{395} 411$ U.S. 1 (1973).

${ }^{396} \mathrm{See}$ id. at 29. While some commentators have been in agreement with the Court's modern characterization of the indigent, see, e.g., ELY, supra note 115, at 162 (arguing that most classifications affecting the poor are not based on prejudice or stereotyped generalizations, but rather on the states reluctance to raise taxes), others have not. See, e.g., Loffredo, supra note 393, at 1367 (arguing that wealth driven politics distort and corrupt the democratic process, and therefore that the impoverished should "comprise precisely the type of politically powerless minority that the Court has deemed worthy of extraordinary protection from the majoritarian political process"). Although Loffredo acknowledges that several welfare programs do exist, arguably attesting to the indigents' political access, he notes that most of these successes result "not from a democratically inclusive politics, but rather from a convulsive mass politics of the dispossessed." Id. at 1329-30. In other words, many social programs originate not out of genuine concern for the poor, but rather because the majority hopes to "purchase social peace and lower-class docility." Id.

${ }^{397}$ Rodriguez, 411 U.S. at 29; see also Memorial Hosp. v. Maricopa County, 415 U.S. 
understanding of "fundamental rights" to only those explicitly or implicitly protected by the Constitution, ${ }^{398}$ (rendering education non-fundamental), its reliance on constitutional definitions of fundamental rights, its acceptance of the earlier indigency cases, ${ }^{399}$ and finally its reliance on federalism concerns to "buttress" its opinion, ${ }^{400}$ paved the way for state constitutional applications of this line of equal protection analysis.

For states that in the spirit of the Warren Court treat wealth classification as suspect, or accord mental health rights constitutional status, their civil commitment schemes should be subjected to strict judicial scrutiny. Analogizing from Rodriguez, states that regard treatment of the mentally ill as a fundamental right, but offer institutionalized care as the only available setting for treatment, would be ideal candidates for strict scrutiny review. As I noted earlier, if a state has not developed community-based alternatives, only the poorest of the mentally ill-those without family support or other material means-face the prospect of involuntary and ineffective treatment in a state mental hospital. ${ }^{401}$ Those less financially strapped, can escape this predicament. Moreover, as several civil commitment statutes are currently designed, evidence of family support actually eliminates the need to commit many of the mentally ill who would otherwise be unable to care for themselves. These individuals are then able to receive treatment voluntarily in the community, while those without family support are subject to involuntary commitments. ${ }^{402}$ Given that only the

254, 269 (1974) (holding Arizona's durational residency requirement for indigents seeking non-emergency hospitalization or medical care to be an invidious classification infringing on the right to interstate travel).

${ }^{398}$ Rodriguez, 411 U.S. at 31-35.

${ }^{399}$ See id. at 17-28. The Court distinguished the wealth discrimination at issue in Rodriguez from other "indigency cases" in two ways. First, the Court emphasized how difficult it is to prove that financing in property-poor school districts disproportionately affects the poor, as compared to the more direct and discrete incidents of poverty discrimination in the criminal trial and appellate processes. As the Court noted, poor individuals may very well live in property-rich districts; and conversely, the rich may very well live in property-poor districts. See id. at 23,28 . Second, the Court noted that disparate school funding did not result in an absolute deprivation of a right, but rather only arguably in a relative deprivation. See id. at 20 .

${ }^{400} \mathrm{See} i d$. at 40,44, 58 (noting how distinctly local both taxing and educational issues are, and how invasive a holding of unconstitutionality would be to the entire Texas educational system); see also supra note 209.

${ }^{401}$ See supra notes $386-87$ and accompanying text.

402 See, e.g., CAL. WELF. \& INST. CODE $\$ 5250$ (d)(1) (West Supp. 1993); Colo. REv. STAT. § 22-10-102(5)(b) (1989); FLA. STAT. ANN. § 394.467(1)(a) (West 1993). Several state statutes provide that if "others" are willing to help satisfy a mentally ill 
poorest of the poor mentally ill receive inferior, institutionalized treatment, such legislative schemes would likely be rendered unconstitutional under state law applications of this equal protection analysis.

As discussed earlier, seven states have constitutional provisions establishing an affirmative right to mental health care. ${ }^{403}$ Several other states have held their public education financing schemes unconstitutional without even relying on separate "education" provisions to hang their constitutional hats. ${ }^{404}$ In these states, it would not matter whether the right to mental health care enjoyed constitutional status, the wealth classification itself would be enough. In each, the argument outlined above would compel courts to review their state civil commitment statutes to ensure true equality of treatment for the mentally ill. If such equality did not exist, these states would be required to develop community-based services either by redistributing funds from state hospitals to

individual's needs, that individual will not be deemed civilly committable. See. e.g., N.J. Stat. ANN. \& 30:4-27.2(h) (West Supp. 1993); N.C. GEN. STAT. \& 122C3(11)(a)(1)(I) (1989 \& Supp. 1992); PA. STAT. ANN. tit. 50, § 7301(b)(2)(i) (Supp. 1993); VT. STAT. ANN. tit. 18, \& 7101(17)(B)(ii) (1987); WYO. STAT. \& 25-10101(a)(ii)(C) (1990 \& Supp. 1993). Moreover, some state statutes provide that if community alternatives are available, individuals who would otherwise be deemed "in danger of harm" are not committable. Conversely, if there are no community-based alternatives, the individual is committable. See, e.g., OHIO REv. CODE ANN. § 5122.01(B)(3) (Anderson 1993); WIS. STAT. ANN. § 51.15(1)(a)(3)-(4) (West 1987). Since some states leave it up to the counties to determine how much money to spend for community-based care, individuals who live in poorer counties would be subjected to commitment while those in richer counties would not. Cf. CAL. WELF. \& INST. CODE § 5670(b) (West Supp. 1993) (providing that "counties may implement the community residential treatment system described in this chapter either with available county allocations or as new moneys become available ${ }^{n}$.

${ }^{403}$ See supra text accompanying notes 343-52 (discussing Arkansas, Idaho, Mississippi, Ohio, Oklahoma, Texas, and Washington). Note that in Arkansas and Washington the courts have had experience applying the wealth classification/ fundamental rights approach to equal protection claims, relying on their own constitutional provisions involving education, to hold their public education financing schemes unconstitutional. See Dupree v. Alma Sch. Dist. No. 30, 651 S.W.2d 90, 95 (Ark. 1983); Seattle Sch. Dist. No. 1 v. State, 585 P.2d 71, $82-83$ (Wash. 1978); see also Robinson v. Cahill, 303 A.2d 273, 294-95 (N.J. 1973) (relying on a New Jersey constitutional provision requiring the state to provide $\mathrm{a}$ "thorough and efficient system of free public schools" to hold its public school financing scheme unconstitutional), cert. denied, 422 U.S. 913 (1975).

${ }^{104}$ See Serrano v. Priest, 557 P.2d 929 (Cal.), cert. denied, 432 U.S. 907 (1976); Pauley v. Kelly, 255 S.E.2d 859, 878 (W. Va. 1979) (ultimately basing its decision on Article III, § 10); Washakie County Sch. Dist. No. 1 v. Herschler, 606 P.2d 310, 332-33 (Wyo.) (relying on a more broadly construed equality provision, Article I, § 34), cert. denied, 449 U.S. 824 (1980). 
community mental health centers or by raising the aggregate level of state funding available for mental health. Although courts may be hesitant to compel tax increases, the concerns of federalism that halted the Rodriguez Court do not similarly exist when state courts dictate to state legislatures. ${ }^{405}$

An alternative to Rodriguez's line of reasoning can also be found in analogies drawn from the Warren Court's judicial process decisions, particularly Tate $v$. Short. ${ }^{406}$ As argued in Tate, the state cannot constitutionally make the payment of a fine the punishment for a wealthy civil offender, but convert the fine to imprisonment for an impoverished civil offender. ${ }^{407}$ Although states have the authority to restrict an individual's liberty, Tate speaks for the proposition that such restrictions should be applied irrespective of economic status. In the context of civil commitment regulations, while the state may restrict the rights of the mentally ill and even institutionalize some individuals, those who are civilly committed should only be committed because of concerns for public safety or the safety of the patients themselves. As we have seen, however, when the state fails to develop community-based alternatives for those who are treatable in the community, the most impoverished of the mentally ill are unnecessarily deprived of their liberty. Alternatively those with familial and financial support are able to avoid the clutches of the state and seek treatment or have treatment provided in other less restrictive settings.

Although all courts should subject these wealth-based disparities in public coercion to strict judicial scrutiny, the unwillingness of the Supreme Court to extend applications of its wealth-classifications beyond the criminal procedure cases ${ }^{408}$ renders federal courts an inhospitable forum for such claims. As for the state courts, while only one court has apparently granted suspect status to wealth classifications, independent of fundamental rights claims, ${ }^{409}$ we

${ }^{405}$ See supra note 209.

${ }^{106} 401$ U.S. 395 (1971).

${ }^{407}$ See id. at 398-99. But see RichaRd A. POSNER, ECONOMIC ANALYSIS OF LAW 227 \& n.5 (4th ed. 1992) (arguing that "fines and imprisonment are simply different ways of imposing disutility on violations," and that the Supreme Court was wrong in Tate, in believing that imprisonment for failure to pay a fine discriminates against the poor).

${ }^{408}$ See TRIBE supra note 200, at 1653; see also supra notes 388-92 and accompanying text.

${ }^{409}$ See Cottrill v. Cottrill Sodding Serv., 744 P.2d 895, 897 (Mont. 1987) (noting in dicta that "wealth . . . is a suspect class" under Article II, $\S 4$ of the Montana Constitution). 
have already seen that fourteen others have interpreted their equal protection provisions more liberally than the federal analog and thus should also be receptive to wealth classification arguments. ${ }^{410}$ Moreover, several courts have applied the logic of Tate v. Short pursuant to their own constitutional provisions. ${ }^{411}$ In each of these states where community-based services have not been adequately developed, strict judicial scrutiny would disclose just how little respect and concern the mentally ill poor are accorded. Therefore, only by equalizing the way the mentally ill are treated in the civil commitment process (that is, only by financing the development of less restrictive alternatives to civil commitment) would these classifications clear the constitutional hurdles of equal protection analysis.

\section{CoNCLUSION}

The mentally ill have faced many challenges in the past. Before deinstitutionalization swept across the United States in the late 1950 s, society handled the disparate needs of the mentally ill by carting hundreds of thousands of individuals off to state-run hospitals. There, they were housed for years, deteriorating both physically and mentally-quickly forgotten by those who had sent them there. In time, however, several forces combined to free the mentally ill from the state's shackles and return them to the society that had discarded them. Promised care and treatment in settings less restrictive to their liberty, the mentally ill looked forward to living normalized lives in the community. Tragically, the promise proved to be a false one. Once back in the community, the same prejudices and hostilities that had previously rendered the mentally ill social outcasts reappeared.

Today, although the era of wholesale institutionalization has surely passed, the mentally ill continue to face powerful challenges to their medical needs and their personal freedom. Two such challenges have been addressed here. First, because of the perceived correlation between deinstitutionalization and homelessness, many states have moved, albeit moderately, towards easing their civil commitment criteria. Second, little has been done to make community-based treatment services a viable alternative to

110 See supra note 384.

${ }^{411}$ See, e.g., Palumbo v. Manson, 400 A.2d 288, 289-90 (Conn. Super. Ct. 1979); State v, Carpenter, 301 N.W.2d 106, 109 (N.D. 1980). 
institutionalization. Of the two, this Comment has sought a solution to the second challenge, not the first.

Although eased commitment criteria threatens to bring many of the mentally ill back to the asylum, it is the dearth of community mental health centers that actually underlies this trend. Consider aftercare services. Had states provided community-based, transitional assistance to the formerly committed mentally ill, "deinstitutionalization" would not have become as forceful a scapegoat for our homelessness problem. Similarly, the current demand for recommitment would not have been as great. Of course, many individuals will always believe that "deinstitutionalization" was a mistake-not because confinement in a state mental hospital is necessarily good, but rather because the loss of state control over the mentally ill has had its costs. But even for those who want states to resume control over the mentally ill, it is difficult to see why community treatment services could not also be developed. The establishment of a right to community-based treatment should, in fact, be compatible with whatever position one takes on the issue of eased commitment criteria. If one favors easing the civil commitment criteria to reach more of the homeless mentally ill, the development of community mental health centers simply provides a less restrictive setting in which to care for these individuals. For those who oppose such an extension of the state's parens patriae power, the development of alternative residential settings simply provides a housing option to those who wish to be housed. In its most liberty-restricting form, therefore, the homeless mentally ill are taken off the streets, and receive care in the least restrictive environment appropriate to their needs. That these possibilities are not mutually exclusive serves only to show that both sides of the debate can disagree on when the mentally ill should be subjected to state coerced treatment, and yet agree on how and where that treatment should be conducted.

In spite of this theoretical common ground, however, there has not been a strong commitment towards the development of community-based services. Although most state civil commitment schemes provide for the consideration of less restrictive alternatives to institutionalization, few states have provided the funding to make these alternatives a reality. Therefore, to compel such funding, this Comment has proposed constitutionalizing the right to communitybased treatment-a right that would extend to the civilly committed, the formerly committed, and those "at risk" of being committed.

Of course, constitutionalizing such a right, and having courts dictate to legislatures on how public funds are to be spent, is not 
uncontroversial. For some, constitutionalizing a right to community-based treatment (even if it extends only to those "at risk" of being committed or already committed before) brings the judiciary beyond the institutional boundaries of self-restraint. Since courts are traditionally envisioned as only interpreting, not making, the law, once these boundaries are crossed, they risk losing their legitimacy as passive, neutral players in our governmental scheme. If state courts lose their legitimacy, they also risk losing their ability to bind the coordinate branches of government and the people to their mandates. A constitutional right to community-based services would mean nothing if the courts could not compel their state legislatures to develop these services.

While it is vitally important that state courts not lose their legitimacy and their effectiveness as the interpretive voices of our constitutional values, it is equally important that state courts not waver in their responsibility to protect the most vulnerable members of our society. As Abram Chayes wrote in summing up his piece on public law litigation, "judicial action only achieves . . . legitimacy by responding to, indeed by stirring, the deep and durable demand for justice in our society." ${ }^{\text {412 }}$ Although recognition of the right proposed here requires state courts to walk a fine line between legal interpretation and legal creation, decision-making that is principled, open and honest would preserve the courts' authoritative voice, while simultaneously advancing the interests of those most deserving of the courts' protection.

412 Abram Chayes, The Role of the Judge in Public Law Litigation, 89 HARV. L. REV. 1281, 1316 (1976). 


\section{$\bullet$}

